DEPARTMEN'T OF THE INTERIOR

UNITED STATES GEOLOGICAL SURVEY

GEORGE OTIS SMITH, DIRECTOR

BuLLeTIN 484

THE

\title{
GRANITES OF CONNECTICUT
}

BY

T. NELSON DALE

AND

' HERBERT E. GREGORY

.

Prepared in cooperation with the

Geological and Natural History Survey of Connecticut

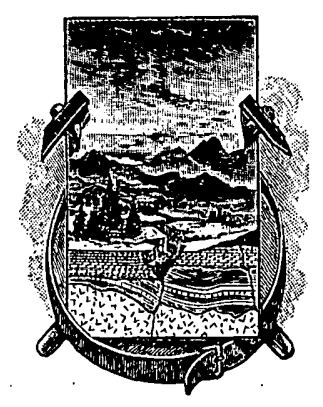

WASHINGTON

GOVERNMENT PRINTING OFFICE

1911 



\section{CONTENTS.}

Tntrondetion

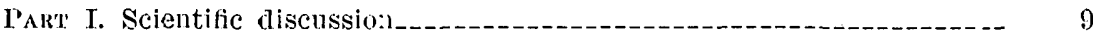

Salient features of Connecticut geology, by Herbert E. Gregory

Origin, nature, and classification of the rocks_-_-_-_-_-_-_- 9

Outline of geologic history of Coninecticut_- 11

Economic geology of the rocks

Granites and granite gneisses of Connecticut, by Ferbert E. Gregory - 14

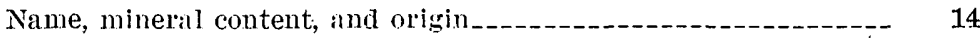

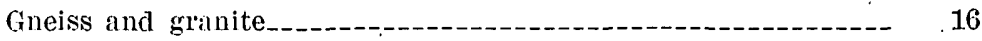

Texture of granitic rocks_-_-_-_- 17

Pegmatite _-_

Porphyry

Distribution of granites and gneisses_-_-_-_-_-_._-_-_-_-_-_-_ 22

Nature of granitic intrusions

Age of the Connecticut granites_._-_-_-_-_-_-_-_-_-_-_ 25

Structure, rock variations, weathering, and discoloration of granitic rocks, by 'T. Nelson Dile_____-__._- 26

General structure-_-_-_. 26

Flow structure

Rift and grain_-__-_- 26

Sheets_-_- 29

Joints_-_-

Headings:-_-_ $3 i$

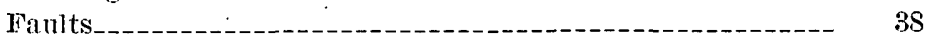

Microscopic finctures _..._-___- 39

Subjoints_-_-_-_-_- 39

Rock variations__-_-_-_-_-_-_- 39

Veins_-_--- 40

Dikes (basic) -

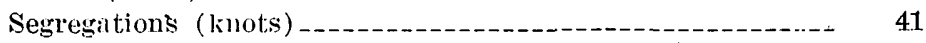

Geodes

Inclusionus_-_-_-_-.-- 42

Discoloration _...- 42

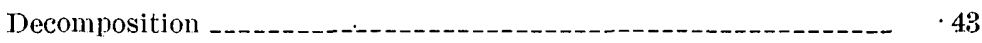

Geologic observations at the quarries, by 'T. Nelson Dille__-_-_-_- 45

Microstructure_._- 46

Iilow structure.-_- 47

Inclusions _.-- 47

Plicated gneiss structure_-_-_-_-_-_-_-_-_-_-_-_-_-_-_-_-_- 47

Grinite dikes_-_-_-_-_- 48

Pegmatite dikes_-_-_-_-_-_- 48

Aplite dikes_-_-_-_-_- 49

Nineral veins_.-. 50

Contacts_-_-_-_-_-_- 50

Sheet structure

Joint structure-_-_- 51. 
PART I. Scientific discussion-Continued.

Geologic observations at the quarries-Continued.

Page.

Segregations_._. 51

Geodes__-_-_- 51

Secondary quartz on joint faces_........... 51

Veinlets of zeolite

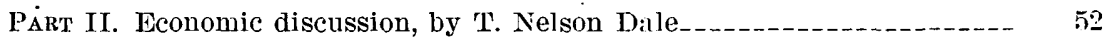

Description of the quarries and their product_-__-_._- 52

Method_-_-_. 52

Fairfield County-_-_- 52

Bridgeport _....-_. 52

Burlison quarry

Jail quarry

Danbury _. 54

Collins quarry_-_- 54

Treadwell prospect-_-_-_- 55

Greenwich

Voorhis quarry -_-_-

Ritch quarry _-_._- 57

Christiano Oak Ridge quarry

Christiano Hamilton Avenue quarry_-_-_-____-_ 59

Norwalk _-_-_._- 59

Hall qualry -...-- 59

Hartford County

General conditions _- 60

Bristol_..._-

Dumn quarry _._.

Seymour Street quarry_-_-___- 62

Glastonbury

Corbin quarry -..-_- 62

Carline quarry

Gorman quarry-_-_- 63

Danielson quarry _-_._-_-_._- 64

Belden quarry -_-_-_._- 64

Curtis quarry

Brooks quarry

Slater quarry -

Litchfield County

Cornwall__._. 67

Benedict quarry

Litchfield _._-_._- 68

Mascetti quarry

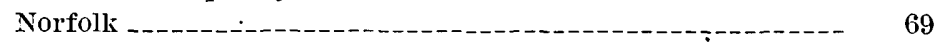

Crissey quarry -_- 69

Roxbury

Rockside quarry

Thomaston _-_-_- 72

Plymouth quarry _-

Torrington _-_-_-_-_-

Costello quarry

Michiel quarry

Torrington Borough quarry 
FArT II. Economic discussion-Continued.

Description of the quarries and their product-Continued.

Litchfield County-Continued.

Warren

Comstock prospect

Page.

76

76

Middlesex County

Middletown _._- 76

Benvenue quarries.

New Haven County-_-_- 78

Ansonia -_-

Potter quarry -_-

Datridson quarry _-_.

Branford _..._. 79

Norcross quarry -_-

Stony Creek quarry

Brooklyn quarry _-_.

Hondly Neck quarries.-_-_._- 85

Guilford -_-_- 87

Leete Island quarry

Silchem Fend quilly

Seymour -_-

Holbrook quarry

New Joudon County

Groton _-_- 91

Silter quarry

M'Tntosi quarry

Eckerlein quarry

Kopp quarry

M'Gaughey quarry

East Lyme__.

Malnati pink quarry -_-_-_- 97

Carlson quarry

Lyme - -

Joshua Rock quarry -_-_-_-_-_-_- 99

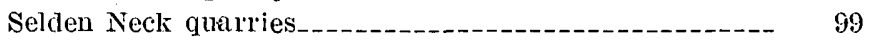

Old Lyme

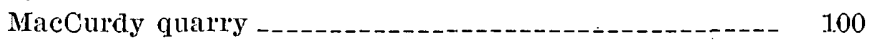

Stonington _.-_ 102

Masons Island qualry

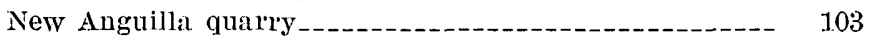

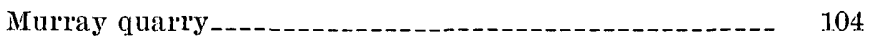

Waterford _.-- 106

Scott quarry -_-

Richards quarry _-_._- 106

Flat Rock quarry

Goos quilry - _.

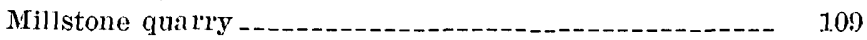

Somers quarry _-_- 112

Waterford quirry --_--_- 113

Tolland County -

Bolton _-

Peterson quarry -1.-1.6 
PART II. Economic discussion-Continued.

Description of the quarries and their product-Continued.

Windham County

Page.

117

Sterling -

Oneco quarry

Marriott quarry

Bennett Bowlder quarry

Sterling quarry

Windham _-_-_-_-_. 121

Larrabee quarry

Classification of the granites

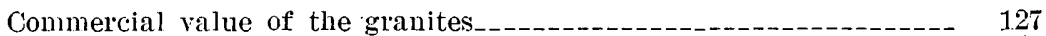

Statistics of granite production, by Altha T. Coons

General economic conclusions

Glossary _._- 130

INDEX -

\section{ILLUSTRATIONS.}

PLATE I. Freliminary geologic and economic map of Counecticut

Page.

.7

II. $A$, Gneiss from Leete Island quarry, showing gneissoid texture due to squeezing and stretching of granite; $B$, Granite from Booths quarry, Waterford, showing granitic texture

III. A, Polished slab of pegmatitic biotite granite gneiss ("Branford red granite" of the trade) from the Norcross quarry at Stony Creek; $B$, Obelisk of hammered pegmatitic biotite granite gneiss ("Branford red granite") from the Norcross quarry at Stony Creek

IV. A, Coarse porphyritic biotite granite gneiss from West quarry. Hoadly Point, Branford; $B$, Porphyritic granite gneiss from Derby --_--_-

V. Sachem Head breakwater granite quarry, Guilford__-_._._._.-

VI. Monument of quartz monzonite from Waterford_.............-

VII. A, Bas-relief of quartz monzonite from Waterford; $B$, Monument of quirtz monzonite from Groton

FigURE 1. Map of part of Greenwich, Conn., showing locations of granite

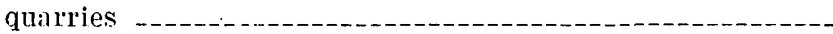

2. Map of Glastonbury granite gneiss quarries.-_-_-

3. Map of Branford and Guilford granite quarries.............-

4. Plicated biotite granite gneiss, West quarry, Hoadly Point, Branford

5. Section of Holbrook quarry in Seymour

6. Structure at Murray quarry, Pawcatuck, Stonington..........-

7. Map of granite quarries in south part of Waterford.......-.--

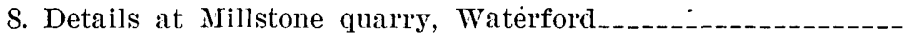

9. East-west section of Waterford quarry-_-_.-_-

10. Relations of granite and gneiss in center of Waterford quarry

11. Discordant sheet structure in granite and gneiss on south wall of Waterford quarry

12. Structure at Waterford quarry 


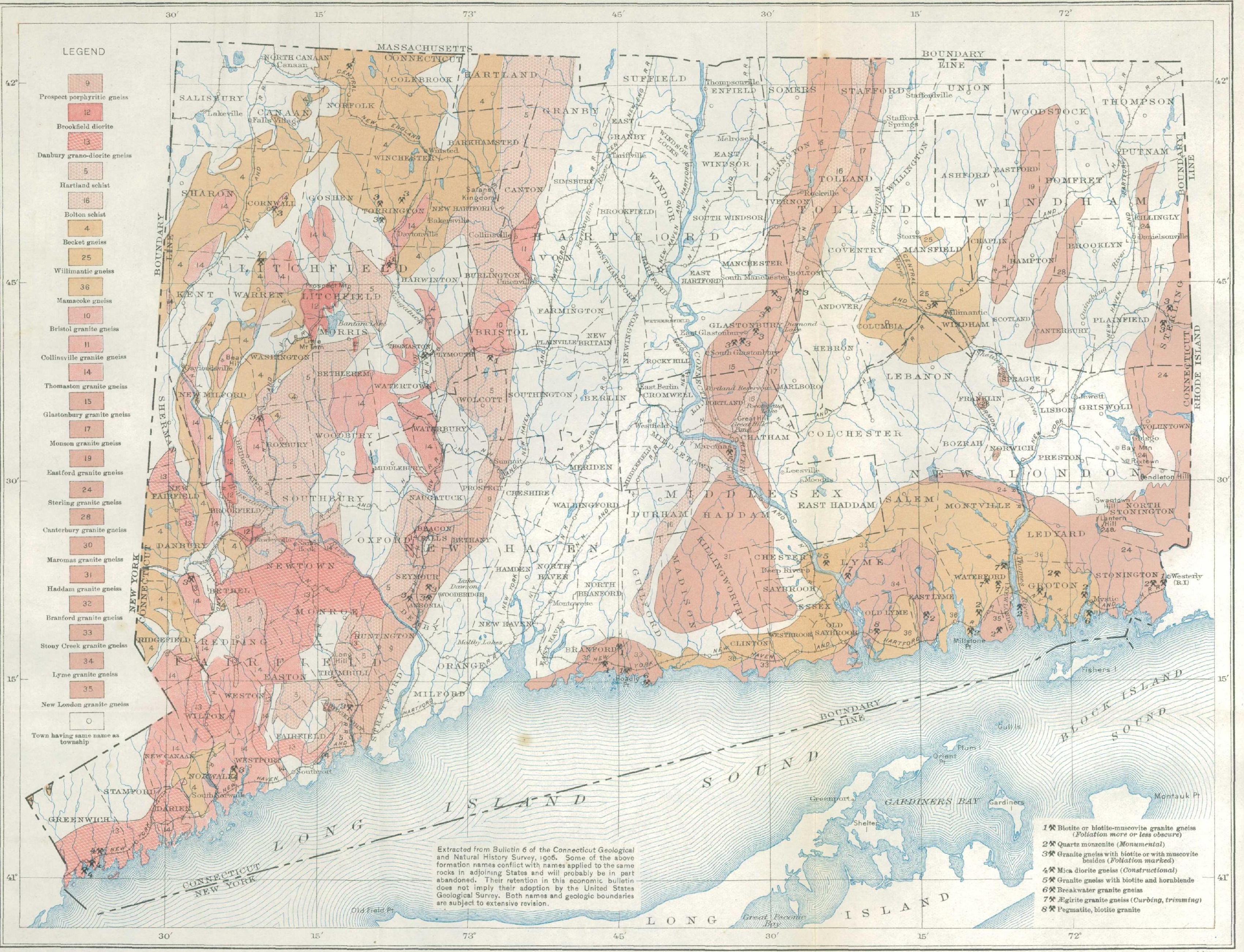




\title{
THE GRANITES OF CONNECTICUT.
}

\author{
By T. Nelson Dale and Herbert E. Gregory.
}

\section{INTRODUCTION.}

This bulletin, like the previous bulletins on New England granites (No. 313, on those of Maine; No. 354, on the principal granites of Massachusetts, New Hampshire, and Rhode Island; and No. 404, on the granites of Vermont), treats of its subject from both the scientific and the economic standpoint, but is so prepared as to make even the scientific portions intelligible to the general reader.

By arrangement between the Director of the United States Geological Survey and the superintendent of the State Geological and Natural History Survey of Connecticut the two surveys have cooperated in the preparation of this bulletin, Herbert E. Gregory, of Yale, University, contributing part of the scientific discussion (Part I) and T. Nelson Dale, of the United States Geological Survey, contributing the rest as well as the economic discussion (Part II). Freeman Ward, instructor in Yale University, has contributed some observations on the Brooklyn quarry near Stony Creek. Miss Altha T. Coons, of the United States Geological Survey, has contributed the statistics of granite production.

The field work, done by Mr. Dale in the fall of 1907 and the summers of 1908-1909, included visits to 63 quarries. He is indebted to F. C. Calkins, of the United States Geological Survey, for the critical revision of his petrographic determinations. R. C. Wells, a chemist of the same Survey, has determined the lime soluble in acetic acid in six of the granites.

The Rosiwal method of estimating mineral percentages has been applied as far as practicable to the types of granite described. These types are scientifically classified on page 123 and are commercially classified, with both their trade and scientific names, in the table on pages $124-126$, which is followed by a section on their relative commercial values.

The word "granite" in the title and in Part II is primarily used in its popular and commercial sense, but many of the commercial 
"granites" of the State are really gneisses-more exactly, granite gneisses-and one is a mica diorite gneiss. The proper scientific names are given in the quarry descriptions as well as the table. The name "quartz monzonite" is applied to granites in which the amount of soda and lime feldspar is almost equal to or even exceeds that of the potash feldspars. The definitions of texture in the descriptions are to be understood as in the previous granite bulletins-coarse, with feldspars generally over 0.4 inch, or 1 centimeter; medium, with feldspars under that size and over 0.2 inch or half a centimeter; and fine, with feldspars under 0.2 inch.

The numbers of the specimens described, to which those of the thin sections correspond, are given, so that the descriptions can be verified by consulting the collections at the National Museum. All the specimens referred to except those from idle quarries were prepared from blocks selected by the foremen or superintendents.

A scientific account of the origin, composition, texture, and physical properties of granite, adapted to the general reader, can be found in United States Geological Survey Bulletin 354, pages 9-17. Pages 18-38 of that bulletin on the structure of granite and its variation and decomposition are reprinted here on pages $26-45$. Such scientific terms as have unavoidably been used in one or both parts of the bulletin are explained in the glossary at the end, where also some of the quarrymen's terms are made intelligible to the general and the scientific reader.

The quarries enumerated include all those that are in operation and a few that are idle, as well as some prospects. The descriptions of their location are based on the topographic maps published by the United States Geological Survey.

The granites of all quarries east of longitude $73^{\circ}$ have been referred to their provisional formation names and numbers on the preliminary geological map of the State, by Gregory and Robinson, 1906, in Bulletin No. 7 of the Geological and Natural History Survey of Connecticut. These names, it must be understood, are given only for reference and may differ from those which will be finally adopted by the United States Geological Survey in its geologic folios. 


\section{PART I. SCIENTIFIC DISCUSSION.}

\section{SALIENT FEATURES OF CONNECTICUT GEOLOGY.}

By Herbert E. Gregory.

\section{ORIGIN, NATURE, AND CLASSIFICATION OF THE ROCKS.}

An examination of the geologic map of Connecticut (Pl. I) reveals the fact that the three large groups of rocks-namely, sedimentary, igneous, and metamorphic-are represented in the State. About 20 per cent of the State is occupied by sedimentary rocks, approximately 5 per cent by unaltered igneous rocks, and the remaining 75 per cent by metamorphic rocks.

The sedimentary rocks of Connecticut include sandstones, conglomerates, and shales and occupy the great central lowland. Originally these rocks were sands and gravels and muds deposited by water. They have since been consolidated into rock, chiefly by the addition of cementing material between the individual grains.

The igneous rocks are chiefly granites and traps. These rocks were once in a molten state and their present solidity is due to cooling. The Connecticut trap rocks are of two classes-diabase, a rock which, like granite, cooled at a depth below the surface; and basalt, a lava which cooled after being poured out on the surface. Diabase is represented by East Rock, Mount Carmel, and the Barndoor. Hills; basalt is well exhibited in the Hanging Hills at Meriden.

Metamorphic rocks are either igneous or sedimentary rocks which have been profoundly changed from their original condition. They have therefore a much more complicated history than either sedimentary or igneous rocks. They are of great antiquity and have been subjected to many of the disturbances which have taken place within the earth's crust since early geologic time.

In order to understand the structure and appearance of metamorphic rocks - which include the gneisses, schists, and marbles of the State-it is necessary to have in mind the physical and chemical forces operating within the earth's crust. Owing to the changing shape of the earth in response to the change from molten to solid form, continuous adjustment among the rocks is taking place both near the earth's surface and below the surface. Adjustments among 
the rock masses are also required by the fact that material is constantly being removed from parts of the land and heaped upon other parts, a process illustrated by the Mississippi, which removes millions of tons of soil and rock from lands along its course and deposits this mass of material 1,000 miles or more from its place of origin. When these adjustments within the earth take place, rocks in different places behave very differently, their behavior depending upon their position with respect to the earth's surface. Rocks at the surface that are subjected to lateral pressure break and leave crevices, large or small, between the broken parts. The fractures may appear as open cracks, or "joints," or as zones of crushed rock, or may be so tightly closed as to escape notice. In places the pressure to which the rocks have been subjected was so great that strata have been broken into blocks, some of them lying obliquely, others tipped on end, and still others retaining their original horizontal position. Such giant blocks are illustrated by the masses of lava forming the broken ridge extending from Meriden to the Massachusetts line.

Rocks buried within the earth to the depth of a mile or more can not adjust themselves by breaking when pressure is applied. The weight of the overlying strata is so great that crevices and cracks can not form, and equilibrium is attained not by sudden breaking but by movement from the place where the pressure is great to other places where the pressure is relieved. The rocks that lie far below the surface behave as if they were so much tallow or wax; in other words, they may be said to flow. Such are the conditions under which metamorphic rocks are developed-conditions entirely unlike those attending the formation of igneous or sedimentary rocks.

The structure and general appearance of metamorphic rocks is accordingly unlike that of igneous and sedimentary rocks and is due to the fact that the rock mass has been forced to move under great pressure-pressure which, with generated heat, is adequate to change completely the shape and texture of the rock, as well as its mineral content. These profound changes that metamorphic rocks have undergone, no matter whether they were originally igneous or sedimentary, have given them their characteristic appearance.

When a ledge of metamorphic rock is viewed from above it is seen to be traversed by innumerable lines, which are the edges of planes along which the rock may be divided into slabs or sheets. When viewed from the side, as in a quarry or railroad cut, these lines or bands are seen to be vertical or oblique. In some places the lines are far apart, so that the rock has the appearance of bedded sandstone or other sedimentary rock which has been turned on end. A little examination, however, will detect the difference, for these metamorphic rocks are composed of crystals, whereas the sedimentary rocks are made of grains held together by cement. The bedding is there- 
fore apparent, not real; it is not an original structure in the rock but is rather the result of pressure. When a metamorphic rock is broken it separates more easily along these lines or bands than in any other direction, and a rock which thus separates along parallel planes is said to be fissile or to possess fissility or foliation-that is, it separates as if it were made of a series of leaves placed together.

Fissility is a phenomenon produced in the deep-seated zone, where rocks may flow but not break. Under pressure the minerals of the original rock have been flattened, and new minerals, chiefly mica, have been developed along the planes of movement. The result is that when a gneiss or schist is separated into layers along these bands the surface of the rock often appears to be coated with black mica. It should be remembered that the metamorphic rock has the same chemical composition as the original from which it was formed and that the change is in structure rather than in composition. Generally speaking, the planes of schistosity in Connecticut run northsouth to northeast-southwest, indicating that the pressure must have come from the east or southeast, but there are many local variations. Metamorphic rocks that actually separate along the planes of schistosity-that is, instead of a tending to separate are actually separatedare said to be fissile or to possess fissility. Fissility may be produced at the surface by weathering or at a short distance below the surface by fracture induced by pressure. Oftentimes in Connecticut the minute crevices opened in this manner may be filled by material carried in ground water or by films of igneous rock thrust into the open spaces. The result is to give the rock a banded appearance, and in some rocks this has gone so far that their entire exposed outcrop seems to be painted over with a series of wavy lines and bands.

In addition to the incipient cracks making up the fissile structure, every ledge shows a series of cracks called joints, which commonly occur in two or more sets, as a rule nearly at right angles to each other. These joints may be parallel with the planes of schistosity, or may cut across them. They are common to metamorphic, igneous, and sedimentary rocks alike, and are not to be considered a fundamental part of metamorphic structure.

\section{OUTLINE OF GEOLOGIC HISTORY OF CONNECTICUT.}

Whether the area now occupied by Connecticut was land or sea at the beginning of geologic time is unknown. It is probable, however, that some of the gneisses and schists antedate the appearance of life on the earth. Unfortunately no fossils have been found in the older rocks of the State, and all that can be said with assurance regarding the age of these formations is that they were in existence long prior to Triassic time. Pre-Cambrian time is believed to be represented by the Becket gneiss, which outcrops over wide areas in 
northern Litchfield County. This rock is, however, so profoundly changed that it is impossible to determine with accuracy the original from which the present complex mass was derived. The limestone and marbles of Canaan and Danbury were probably deposited in Cambro-Ordovician time, and the material forming these rocks is believed to have been furnished by high land masses located east of the Rhode Island border-lands which long ago disappeared.

The geologic history of the immensely long time represented by the Silurian, Devonian, and Carboniferous ages has not yet been completely deciphered. Whether rocks belonging to these ages exist in western Connecticut is unknown, but the metamorphosed equivalents of Carboniferous sediments are represented in the eastern part of the State. Though much doubt exists regarding the Paleozoic sedimentary record, there is abundant evidence for the statement that at frequent intervals during these ages igneous intrusions occurred. Masses of igneous rock, which occur as minute dikes and sheets, may be considered as remnants of larger masses, which were poured out on the surface or hidden beneath the overlying strata.

Moreover, an examination of the schists and gneisses of the State reveals the fact that all rocks older than the Triassic sandstone have been involved in movements within the earth's crust, and have accordingly been so much metamorphosed as to destroy all fossils which they may have contained, and to modify the rocks themselves beyond recognition. The dates when these far-reaching changes took place are believed to coincide with the mountain-making epochs marking the close of Ordovician and of Carboniferous time. The extent of these changes and their fundamental character are revealed by a study of the metamorphic rocks of the State.

These rocks are chiefly schists and gneisses, and accordingly have structures indicating that they have been profoundly changed from their original sedimentary or igneous character. The original component minerals have been rearranged, stretched, and drawn out in lines; new minerals have been produced; parts have been fused and recrystallized. Instead of horizontal layers or uniform igneous masses, we find twisted and broken rock with layers, bands and ribbon structures in every conceivable position. Moreover, this tangle of structure is further complicated by the presence of dikes, seams, and veins which have made their way into the rock at different stages of its history. In looking at this confused mass of rock which forms the Connecticut crystallines it seems apparent that it has taken part in manifold changes which went on in the earth's crust for ages. ${ }^{1}$

The mountains and plateaus of Carboniferous time were worn down during Triassic time, and the materials of which they were composed have gone to make the sandstone of central Connecticut. The amount of rock removed from Connecticut prior to Triassic time may be judged from the appearance of the rock immediately under-

${ }^{1}$ Bull. Connecticut Geol, and Nat. Hist. Survey No. 6, p. 80. 
lying the Mesozoic strata. 'The structure of the schists which form the floor of the Triassic is such as can be produced only at depths a mile or possibly several miles below the earth's surface. . We may be reasonably sure, therefore, that mountains of folded strata once occupied Connecticut and that the granites and gneisses and schists which we see are but the stumps of lofty land masses " rivaling the Alps in height and ruggedness."

During the formation of the conglomerates, sandstones, and shalesa time proved by dinosaur and fish remains to be Triassic-lava was poured out over central Connecticut and possibly over the entire State. Remains of these flows of basalt now stand as a ridge separating the valleys of Farmington and Connecticut rivers. During Cretaceous time the highlands were lowered and the entire surface was reduced practically to a plain sloping from northwest to southeast, and the Cretaceous sediments now exhibited on Long Island probably also covered southern Connecticut. This plain (peneplain) formed during Cretaceous time was uplifted during early Tertiary time, and the streams were thereby given greater eroding power and began at once to deepen and widen their valleys. Continued erosion during the millions of years comprehended in Tertiary time resulted in giving to Connecticut the larger features of valley and hill, highland, and lowland, which exist at the present time.

During the Pleistocene ("glacial") epoch the surface features of Connecticut were again remodeled. The more prominent erosion forms of Tertiary time remained, but the details of the scenery were completely changed. Hills were rounded off, valleys were filled, and the entire State was covered with a mantle of glacial débris. Drainage lines were rearranged and the lakes, swamps, and bogs so characteristic of the State were formed. Decomposed rock and "rotten rock" were largely removed from the ledges, leaving fresh rock near the surface. This last-mentioned result of glaciation is of interest to quarrymen, as the expense and difficulty of procuring commercial stone have thereby been greatly lessened.

\section{ECONOMIC GEOLOGY OF THE ROCKS.}

Four types of rocks in Connecticut are used commercially. The limestone or marble of the western and northwestern parts of the State has in times past been used extensively as structural material; at present it is chiefly used for making lime. In 1908 Connecticut ranked No. 12 among the lime-producing States.

The Triassic brownstone of the central part of the State, quarried chiefly at East Haven and Portland, has long been used for structural purposes in the larger eastern cities. In fact, the quarry at Portland is, so far as known, the first sandstone quarry worked in America, and 
has supplied stone for several buildings, monuments, and bridge piers dating from prerevolutionary days.

The trap, including both diabase and basalt, which extends in two irregular lines from Long Island Sound to the Massachusetts border, is widely used for concrete construction, road making, and railroad ballast. Connecticut is one of the six States which produce trap rock in large quantities.

Granite, though quarried at relatively few places in this State, has steadily increased in importance until its annual production exceeds in value the sandstone, limestone, and trap. The increasing demand for granite and the relative ease with which it may be quarried in Connecticut, taken in connection with facilities for transportation by rail and boat and nearness to New York and other large cities using. this stone, promise a satisfactory future for this industry. It is also probable that the granite gneisses of the State not now largely used will become important in the stone industry of New England. Several localities would doubtless repay extensive development, as sources of structural materials and certain of the finer grained varieties are destined to be used as road metal. The pegmatites, or "giant granites," furnish feldspar for commercial uses, and the wide distribution and favorable location of rock of this type has given Connecticut first rank among the States as a producer of crude feldspar.

\section{GRANITES AND GRANITE GNEISSES OF CONNECTICUT.}

By Herbert E. Gregory.

NAME, MINERAL CONTENT, AND ORIGIN.

Granites are igneous rocks composed chiefly of feldspar and quartz. Some granites include no other minerals, but all the Connecticut granites so far observed contain other minerals in large or small amounts. If feldspar and quartz are considered as essential ingredients it is easy to classify granite in accordance with the presence of the additional minerals, and thus we have biotite granite, hornblende granite, and other varieties. As used commercially the term granite includes not only granite but many granite-like rocks which differ considerably in structure and in composition, and to which names are given that are suggested by some unimportant surface appearance. Thus, although the scientific classification of Connecticut granites, including gneisses, recognizes ten groups, the commercial or trade classification includes twenty varieties, discriminated by structure, texture, composition, and appearance.

In addition to feldspar and quartz, the Connecticut granite and granite gneiss contain muscovite, biotite, hornblende, pyroxene, 
titanite, allanite, pyrite, apatite, zircon, and magnetite. Most of these minerals are of rare occurrence and few of them are of economic importance. In fact, all the igneous rocks, including the granites and granite gneisses, consist chiefly of but five minerals; feldspar forms 59 per cent, quartz 12 per cent, biotite 4 per cent, hornblende and pyroxene taken together 17 per cent; in all, 92 per cent. A knowledge of the mineral composition of a granitic rock that is offered for sale as a building material is of distinct practical value to the intending purchaser, but the ability to recognize only these five minerals and pyrite, which is a source of weakness and discoloration, is sufficient for all ordinary purposes.

Quartz occurs in granite as irregular, widely scattered grains, apparently filling spaces between the other minerals. Its hardness, glassy appearance, and diverse or irregular form serve to distinguish it from other minerals.

Feldspar is of many varieties and in its scientific classification much is made of the different species, but most of these different varieties can be distinguished only by the proficient petrographer, and in an examination of the rock with the naked eye all the feldspar may be considered as of one variety. In the finer-grained rocks, especially those in which the feldspar has been crushed (such as gneiss), feldspar may be mistaken for quartz by the careless observer, but ordinarily it may be distinguished from quartz by its opaqueness and by the fact that it cleaves along plane surfaces, from which light is reflected. In the coarser-grained rocks the feldspar crystals tend to assume rectangular shapes and in some of the porphyries they are large and are nearly perfect in shape.

Biotite, a dark mica, appears in the granites as dark specks and may be distinguished from all other minerals by its tendency to split into thin flakes, the surfaces of which are lustrous. The larger crystals of biotite which occur in the coarser-grained rocks and in the gneisses are so readily recognized that they do not require description, and the plates of mica (both muscovite, a light mica, and biotite), several inches in diameter, which are found in certain pegmatites and furnish the mica of commerce, are even better known.

Hornblende and pyroxene can not usually be distinguished from each other except by a trained mineralogist. Both are commonly black, but may be distinguished from biotite by their greater hardness and their lack of elasticity, and by the fact that ordinarily they occur in little prisms or needles, instead of flakes, the common form of the micas. Biotite, hornblende, and pyroxene occur together in many kinds of rocks, but in those in which quartz is present, such as the granites and granite gneisses, biotite may be common, hornblende much less so, and pyroxene may be absent, so that practically the only 
dark-colored minerals other than quartz and feldspar which need to be distinguished are biotite and hornblende.

Pyrite occurs in granites and granite gneisses in scattered crystals in amounts so small that it ordinarily escapes observation. This mineral is well known because of its resemblance to gold in luster and color, though it differs from gold in that it is harder and in that its particles are of angular form. The presence of pyrite in a building stone should be noted, for it weathers more readily than any other common mineral, and the stone containing it is thereby weakened and is liable to discoloration.

As has been already stated, granites are of igneous origin, that is, they were formerly in a molten state and have crystallized by cooling. Both their texture and their mode of occurrence indicate that they attained their present character while they were deeply buried within the earth. The removal of thousands of feet of. rock that rested upon these granite masses has had little effect upon their composition, texture, or general appearance, and the rock exposed in the quarries is essentially like that which lies deeply buried but which may be uncovered by erosion in other parts of the State at some future time.

\section{GNEISS AND GRANITE.}

Before the.structure and texture of rocks usually called granite are described it may be of advantage to understand the difference between granite and gneiss, both of which are quarried in Connecticut. Granite is a massive rock in which the minerals are not definitely arranged in sheets or bands; neither in the hand specimen nor in the ledge will. marked variations in the size of crystals and their arrangement be observed. (See Pl. II, B.) Both granite gneiss and granite consist of crystals resulting from igneous fusion and are thus entirely unlike sedimentary rocks which are aggregates of preexisting fragments. Gneiss differs from granite in being a metamorphic rock and thus in possessing gneissoid and other structures not found in granite. Gneissoid structure in a rock is marked by lines or bands that divide surfaces along which the rock may be separated into sheets, slabs, or "beds." The sheets may be all of the same material or may be of different materials; for instance, sheets consisting largely of biotite and feldspar may alternate with sheets that are prevailingly quartzose, and even in rocks in which bands and sheets are not well developed a distinct parallel arrangement of the minerals is noticeable. (See Pl. II, A.)

Granite gneisses have been formed from granites, the change being chiefly a rearrangement of the mineral particles. The micas and other minerals are drawn out along well-marked planes; and new micas, both muscovite and biotite, have been produced. Gneiss may' 


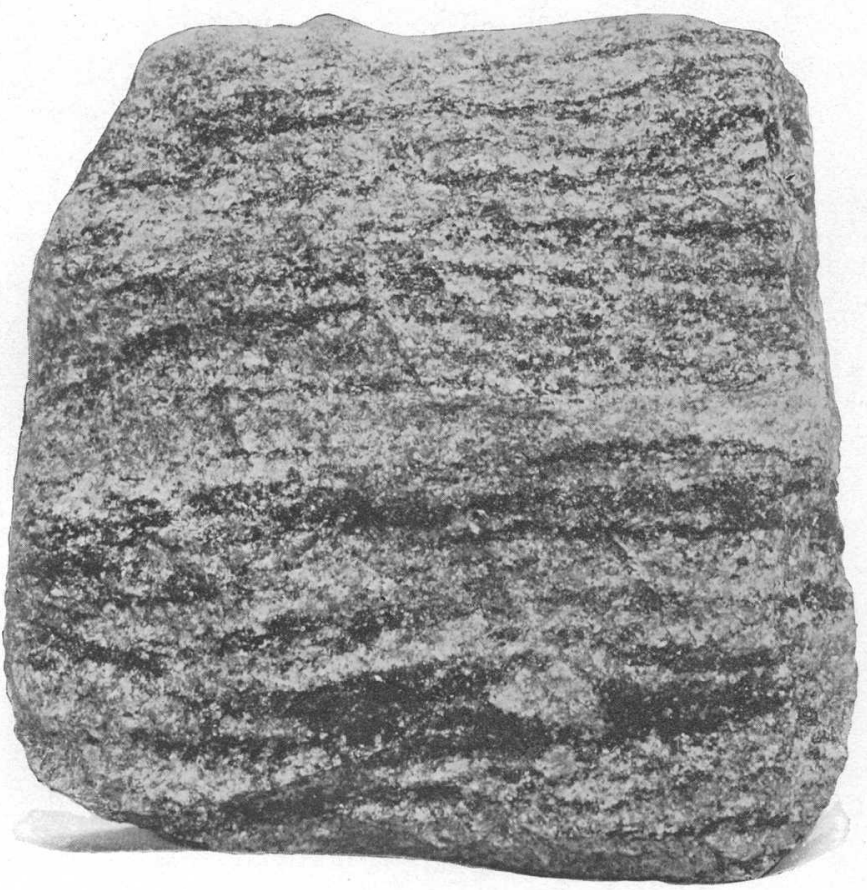

A. GNEISS FROM LEETE ISLAND QUARRY.

Showing gneissoid texture due to squeezing and stretching of granite. See page 16.

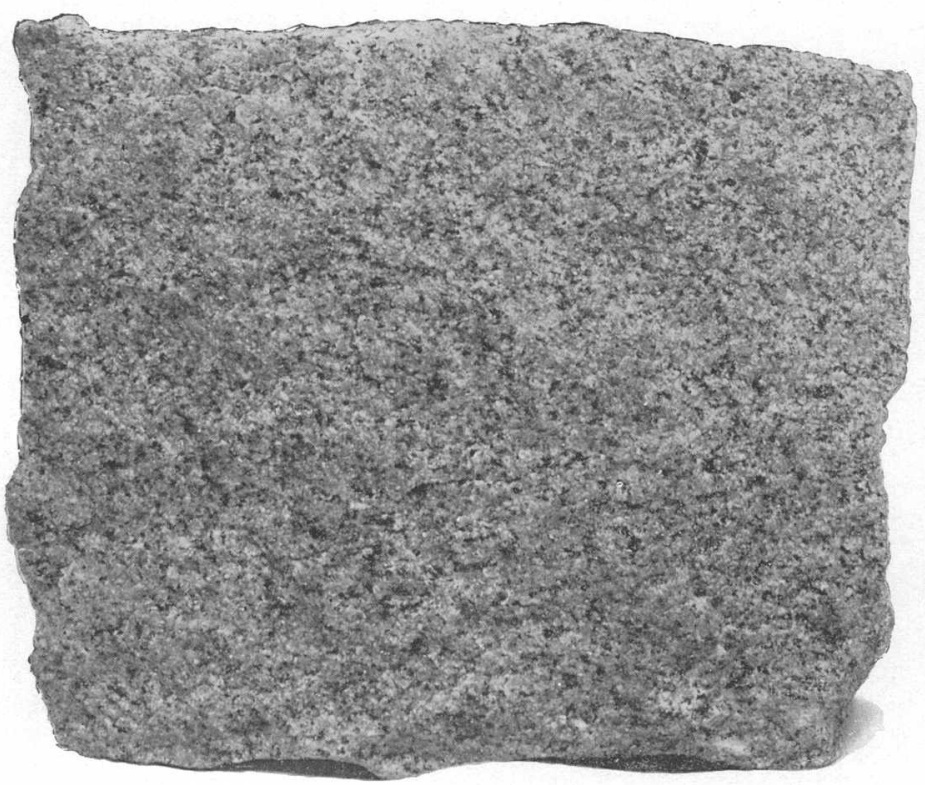

B. GRANITE FROM THE BOOTH QUARRY, WATERFORD.

Showing granitic texture. See page 16 , 
also contain tourmaline, garnet, and other minerals that are not generally found in granite. The chemical composition of the rock may remain unchanged after the metamorphism, the only difference between the granite and the gneiss being a change in structure and in the relative abundance of minerals. If the original granite was porphyritic, the granite gneiss is likely to be a porphyritic granite gneiss. The difference in appearance between the granite and the gneiss will depend on the amount of metamorphism the rock has undergone. Occasionally the two types will appear in the same quarry, as in the Stony Creek region. Elsewhere the granite will have been so profoundly changed that all likeness to the original granite mass has been destroyed.

The common types of gneiss in Connecticut are mica or granite gneiss and hornblende or diorite gneiss. The mica gneisses are ordinarily squeezed, mashed, and drawn-out modifications of granite and related igneous types. 'The production of gneiss is facilitited if granite intrusions occur in the region and thus furnish feldspar: to be added to the rock during the process of alteration. The hot mass promotes the formation of solutions that carry abundant feidspathic material out of which feldspar can be made. Much of the beautiful banding in gneiss is produced not by the common process of development of minerals under pressure but by the intrusion of foreign material along the planes of schistosity. An outcrop of ordinary granite gneiss exhibits bands of granitic material separated by thin micaceous bands, but certain granite gneisses have, in addition to the foliation-structure effected in the zone of flowage, a series of bands composed of light or dark colored rock which were originally no part of the constituents. ${ }^{1}$

\section{TEXTURE OF GRANITIC ROCKS.}

The texture of granite and granite gneiss is important economically as well as scientifically. By texture is meant the smaller details or features of a rock-" the fabric of the mass"-such as would be noticed in a hand specimen, as contrasted with structure, a term which signifies the larger features, to be observed only in the field. Igneous and metamorphic rocks show great variations in texture. The individual grains or imperfect crystals of which a granite is composed may be all of one size or may be of two or more different sizes; they may be too small to distinguish with the unaided eye or they may be an inch or even several inches in diameter. This wide variation in the appearance of granite is the result of the conditions under which the rock was consolidated and has little. to do with its chemical composition. In fact, a large granite mass may show all the differences mentioned above. The physical factors chiefly concerned in determining the texture of granite are the presence of water vapor and the rate of cooling. Water vapor is held in rock at great depths and its presence tends to lower the fusing point and to pro-

1 Bull. Connecticut Geol. and Nat. Hist. Survey No. 6, p. 67. 
mote circulation in the uncooled mass. The presence of water vapor in large quantity causes the formation of coarse crystals, such as are seen in pegmatite. (See below.) The rate of cooling is also of fundamental importance in determining size of grain. Rapid cooling allows no time for crystallization, and in general it may be said that the slower and more evenly a molten mass cools the larger and more regular are its crystals. As different minerals crystallize at different temperatures, minerals will form in a molten rock mass in a more or less regular order as the mass cools. For the chief constituents of granites this order is pyrite, hornblende, biotite, feldspar, quartz. It is thus easy to understand why well-formed crystals of pyrite are seen in some granites that contain poorly developed crystals of feldspar and in which quartz seems merely to occupy the space left between the better-formed crystals.

Two textures observed in Connecticut granites and granite gneisses, are worthy of special mention-the pegmatitic and the porphyritic.

\section{PEGIMATITE.}

Pegmatite is essentially a coarse-grained rock composed largely of feldspar, quartz, and mica. In color the quartz may be gray, white, or pink (rose quartz), and it may occur in masses that range in diameter from 6 inches to several feet, or may be intergrown with feldspar to form large masses of these two minerals alone, with practically no mica. Both muscovite and biotite are commonly present in the pegmatites, the crystals of muscovite having dimensions of 2 to 6 inches across and in some rocks being so large and pure as to make this mineral commercially valuable. Biotite is more likely to occur in small sheets or along flat plates set into the rock at all angles and when viewed on the surface gives the ledge the appearance of being cut across by thin dark blades of this mineral. "Slashed granite" is a term used locally to distinguish rock having . this appearance. In addition to the quartz, feldspar, and mica, other minerals occur sparingly or abundantly in pegmatite, chief among them being garnet, beryl, and tourmaline. Some pegmatite dikes are so rich in minerals that they serve as collecting ground for museums. The pegmatite veins along Connecticut River have yielded sphalerite, gahnite, magnetite, chrysoberyl, bismutite, orthoclase (crystals), albite, oligoclase, beryl, iolite, garnet, epidote, tourmaline, muscovite (crystals), lepidolite, biotite, columbite, samarskite, monazite, triplite, torbernite, autunite, and uraninite. From a single pegmatite mass at Branchville twenty-seven minerals were collected. Single crystals taken from this mass weighed 100 to 200 pounds. The proportions of the chief minerals in pegmatites varies greatly. Some dikes or veins contain quartz, feldspar, and mica in 
about the same proportions as those found in normal granites. In other dikes feldspar and quartz make up practically the entire mass, and in some localities quartz alone constitutes probably 90 per cent of the entire rock.

Pegmatite or pegmatitic granite is associated with nearly all the granite and granite gneiss bodies in Connecticut. In the granite quarries it commonly occurs in irregular masses, more or less lensshaped, and may appear within the granite mass itself, where it grades imperceptibly into the even-textured variety, or may exist as dikes having distinctly defined walls. Outside the granite quarries, in the granite gneiss of the State, it occurs either as definite veins or dikes or as groups of veins, and in certain localities, particularly in the towns of Plymouth and Portland, it forms large.masses a quarter to a half mile wide and a mile or more long. Considering the State as a whole the pegmatites are rather more common and more widely distributed than the true granites. Where pegmatite forms the surface rock the topography is controlled by it and is characterized by an irregular surface of knobs and ridges. On most of the higher land in regions of granite gneiss the pegmatite stands out prominently and may be recognized from a distance by its white color, which has given the name "White Rocks" to several places in the State.

The contact between the pegmatites and the gneiss or other rock into which they have been intruded is clearly defined, showing no gradation between the pegmatite and the gneiss. In the feldspar quarries of Glastonbury, where the contact may be clearly traced, the gneiss immediately adjoining the pegmatite retains all the minute structures of foliation and differs in no way from the main body of granite gneiss.

Pegmiatite may be regarded as a form of granitic intrusive that originated in parts of the igneous mass which were abundantly supplied with water vapor. Most masses of pegmatite were formed in a manner somewhat different from that in which ordinary granite was formed, and their composition varies with their distance from the granite mass. For instance, in the Collinsville granite gneiss area the pegmatites that are closely associated with the granite mass, such as those at Canton, are of essentially the same mineral content as the granite. The pegmatite farther away, which cuts the schist overlying the granite, is composed chiefly of quartz and feldspar, and that which lies still more distant is formed entirely of quartz. It is believed that the schist overlies the granite gneiss and that the pegmatite dikes are veins or stringers originating in the granite mas: but extending for considerable distances into the overlying rock. The upper part of such stringers was far removed from the molten mass and is believed to owe its existence chiefly to water vapor. It 
therefore seems necessary to assume that pegmatite results either from aqueous solution or igneous injection or from a combination of the two, and thus may possess the character either of true veins or of dikes.

Only the pegmatites that occur as phases of granite or granite gneisses are used for structural purposes, and these rocks are of economic value only because they are the source of quartz, feldspar, ${ }^{1}$ and mica. Pegmatite veins or dikes are commonly found at the borders of granite gneiss areas, as in the Middletown district, where four quarries are in operation at the contact of the Glastonbury granite gneiss with the "Bolton" schist and two at the edge of the Maromas granite gneiss. The chief active pegmatite quarries now worked for feldspar are along Connecticut River, in the towns of Middletown, Haddam, Chatham, Portland, and Glastonbury, but feldspar is also quarried in Fairfield, Litchfield, and New Haven counties.

\section{PORPHYRY.}

Generally speaking, the granite and granite gneiss of Connecticut are composed of crystalline grains of nearly uniform size. Certain granites and gneisses, however, exhibit a marked variation from this texture in that one or more of the constituent minerals occurs in much larger crystals than the others. The rock thus has the appearance of a fine-grained granite in which larger crystals are embedded. A rock having this texture is known as porphyry, the larger crystals of which are called phenocrysts-that is, easily seen crystals-and the remainder of the rock the groundmass.

The principal mineral that occurs as phenocrysts in the Connecticut gneisses and granites is feldspar, and the largest crystals are a hundred times larger than the crystals forming the groundmass. Porphyritic texture is believed to indicate in general an interruption in the process of crystallization. It is assumed that at first the conditions were favorable to the formation of large crystals but that before the rock could completely solidify on this scale a change in physical conditions occurred, by which the material not yet crystallized was solidified in smaller grains. Gneisses showing porphyritic texture may have been formed from preexisting porphyritic granite or the phenocrysts may have developed during the change from igneous to metamorphic rock. If the latter supposition is correct the phenocrysts formed after the development of the gneissoid structure seem to be the result of absorption and enlargement of crystals during the period of relative quiet which followed the period in which great dynamic forces produced metamorphism. Great heat and moisture

1 For detailed description of feldspar quarries of Connecticut see Bull. U. S. Geol. Survey No. 420 . 
in the rocks would be necessary conditions of this change. In those rocks in which further metamorphic change has occurred after the phenocrysts were formed the crystals are drawn out along the planes of schistosity, and some have assumed a lenticular shape, and their ends have been drawn out into lines of broken fragments. This is well shown in the porphyritic gneiss about Derby. ${ }^{1}$

The character of porphyritic gneiss, its general appearance, and the theory of its origin may be understood from the following detailed description of the porphyritic Prospect granite gneiss, one of the Connecticut rock types which is destined to be used commercially.

The formation consists of a light-gray porphyritic gneiss. The gneissoid appearance is produced by bands of granular quartz and feldspar interbedded with layers composed chiefly of biotite. Muscovite, garnet, chlorite, zircon, and titanite occur with the more abundant constituents. Within the groundmass formed of these minerals there are set larger crystals of feldspar, mostly orthoclase, white or pink in color, thus giving the gneiss a porphyritic texture (PI. IV , B , p. 84). These phenocrysts vary from one-sixteenth of an inch to 3 inches in their longest diameter, are quite fresh and regular, and nearly all show twinning structure. Besides the typical coarse porphyritic gneiss there occur in this formation small areas of porphyritic granite with inconspicuous gneissoid development and narrow bands of mica schist distributed unevenly and not attaining the prominence which these beds have in the Becket gneiss. Pegmatite is rarely found. At its extreme northern limit the Prospect gneiss is prevailingly less porphyritic and more quartzose and contains areas of intrusive basic rocks.

This formation is believed to have been originally a mass of porphyritic granite intruded into the Hartland (Hoosac) schist. No contacts are visible, however, and direct proof of the date and nature of the intrusion is not at hand. Metamorphic processes have converted the rock into a gneiss with planes of schistosity whose strike averages about $\mathrm{N} .25^{\circ} \mathrm{E}$. The character of the original rock was so clearly marked that the changes induced by folding and metamorphic action are readily traced. The phenocrysts of orthoclase were originally set at various angles in a granite groundmass. Some of these were so oriented as to resist effectively the metamorphic forces and consequently remain in their original condition, except that they are somewhat flattened, crushed at the ends, and converted into microcline. The phenocrysts less favorably situated have been squeezed, broken, and rotated into parallelism with the planes of schistosity. Many original crystals are represented by lenses and eyes of granular feldspar and quartz, and in some all traces of the crystal are lost in the general gneissoid structure of the grouindmass.

${ }^{1}$ Bull. Connecticut Geol. and Nat. Hist. Survey No. 6, p. 60. 
Besides the granular bands produced by metamorphism of the quarti and feldspar of the original rock, much new biotite and garnet have been formed, and, in less amounts, the other minerals mentioned above. The mica wraps about the feldspar phenocrysts and is closely adjusted to it. Because of the unequal amount of metamorphism the Prospect gneiss varies from porphyritic granite, through gneiss containing flattened nodules, to a rock in which crushing and rearrangement has been so great that it has become a feldspathic mica schisi.

The prospect gneiss is not porphyritic throughout its extent. Its western extension assumes a typical granitic texture. ${ }^{1}$

\section{DISTRIBUTION OF GRANITES AND GNEISSES.}

The areas of granite gneiss in Connecticut are shown on the map forming Plate I. The true granites occur in masses so small that they are not shown on this map. In fact, unchanged granite occupies probably less than one-half of 1 per cent of the 4,990 square miles of the State. It will be noticed that the granite gneisses occur either as long, narrow bands, as illustrated by the Glastonbury and Monson gneisses, in larger areas of irregular outline like the Sterling and Becket gneisses, or in rock masses surrounded entirely by schist, as at Bristol and Collinsville. As all of the granite gneisses of the State are adapted for use as structural material, and some of them also for road metal, and as those who are interested, in the quarry industry may wish to examine these various types of granite gneiss, the following brief description is given of the more important formations: ${ }^{2}$

Becket gneiss.-Is light gray in color, of firm texture, and has a uniform banded structure. In many places the rock is highly quartzose and granular. The formation includes many veins of quartz and pegmatite. Supposed to be of pre-Cambrian age.

Prospect porplyyritic gneiss.-Is. light gray in color. The gneissoid appearance is produced by bands of granular quartz and feldspar interbedded with layers composed chiefly of biotite. The porphyritic mineral is usually orthoclase, white or pink in color, varying from one-sixteenth inch to 3 inches in length. The rock is believed to have been a granite porphyry intruded into the Hartland schist.

Bristol granite gneiss.-Typical rock is light gray, with gneissoid structure more or less developed by the presence of layers of biotite; more schistose layers contain muscovite. An evenly banded hornblende gneiss occupies part of the area. Garnet is nearly everywhere present and in places rises to the rank of a principal mineral. The rock was originally a mass of granite and diorite intruded into Hartland schist.

Collinsville granite gneiss.-Two types appear intermingled without order, a light gray, heavy-bedded rock, grading into massive granite, and a very dark gray to black variety, which grades by imperceptible stages into evenly banded hornblende gneiss. The rock consists of feldspar, largely orthoclase, quartz in

1.Bull. Connecticut Geol. and Nal. Hist. Survey No. 6, pp 102-104, and 60.

2 Abstrated from Bull. Connectict: Geol, and Nat. Hist. Survey No. 7, pp. 33-38. 
irregular grains, and biotite. Was originally granite and diorite intruded into Hartland schist.

Brookfield diorite.-Is usually massive, but shows also gneissoid and even schistose phases. Both light and dark types are present, the former containing much quartz, and in extreme cases no dark mineral except biotite. The dark variety shows an almost complete absence of quartz, and in its place dark hoinblende. It is an igneous mass intruded into the quartzite and schists of this region.

Danbury granodiorite gneiss. - The rock presents two important facies-a biotite granite and a diorite in which hornblende becomes an important constituent and quartz is less prominent. There are gradations between the two types, It is prevailingly porphyritic, with pink or white phenocrysts of feldspar, is igneous in origin, and was intruded prior to the time when metamorphic action converted igneous and sedimentary rocks alike into gneisses and schists.

Thiomaston granite gneiss.-Rock variës in structure from an almost massive granite to a rock with distinctly schistose phases. It is of igneous origin; as shown by the fact that it often occurs as dikes, and fragments of other rocks are included in it.

Glastonbury granite gneiss.-Two types-a granitic biotite gneiss or a biotite granite, in a narrow band along the eastern border, and a darker, well foliated gneiss, with biotite, hornblende, and epidote, in the remainder of the area. Both massive and schistose phases sometimes become augen gneiss. Believed to be of igneous origin.

Monson granite gneiss.-Where typically exposed, the rock is a fine-grained, dark-gray. uniform biotite-hornblende.gneiss, marked at short intervals by parallel seams of quartz, and with bands of biotite and hornblende. It is believed to be of igneons origin.

Lustford granite gnciss.-In general, a light or dark gray gneiss, fine grained, or in places even porphyritic. The composition and texture show the rock to be of igneous origin.

Sterling granite gneiss.-The rock is pink or gray in tone, and is made up of two distinct types-a porphyritic gneiss with an abundance of biotite along foliation planes, and an aplite or granite gneiss practically free from mici. The porphyritic type is always highly gneissoid and the phenocrysts of pink feldspar are drawn out into lenticular forms. Where phenocrysts are absent the rock shades into a normal granite, which is intermediate between the two above-mentioned types. The aplitic type is probably a later intrusion than the porphyritic and normal types. Origin. igneous.

Willimantic gneiss.-In general, the rock is coarse grained and often porphyritic in structure, usually considerably crumpled and folded. There are two varieties, the light and the dark. The light variety consists of quartz, feldspar, and biotite, in the proportions of a normal granite. The dark variety contains a relatively smaller amount of feldspar and quartz, with a larger amount of biotite and some hornblende. Origin, igneous.

Cantcrbury granite gneiss.-The formation consists essentially of a muscovitebiotite gneiss, varying in texture from a fine, even-grained rock to a porphyry with feldspars a quarter of an inch or so in length. Metamorphism has produced irregular wavy bands of biotite separated by flattened layers of quart\% and feldspar. Origin, igneous.

Maromas granite gneiss.-It is in some places massive, but usually well foliated. Composition is that of a normal granite. (See Sterling granite gneiss.) This rock is eruptive, and is intruded into the Bolton schist. 
Haddam granite gneiss.- it is a light-colored, rather fine-grained, granitic aggregate of quartz and feldspar, through which are scattered small isolated flakes of biotite. In the outcrops the rock is a moderately thick-bedded gueiss. Origin, igneous.

Branford granite gneiss.-The rock is a medium-grained granite with a banded structure, consisting very largely of white feldspar. In the feldspars are embedded small round quartz grains, and biotite is also present in about equal amount. Small reddish garnets commonly occur, but may fail entirely. The rock has a pronounced tendency to weather, with a brownish stain on the cleavage surfaces of the feldspar. Origin, igneous.

Stony Creek granite gneiss.- See Sterling granite gueiss.

Lyme granite gneiss.-See Sterling granite gneiss.

New London granite gneiss.--See Sterling granite gneiss.

Mamacoke gneiss.-The rocks occupying the larger areas of this formation are decidedly gneissic, sometimes containing much biotite, and more rarely hornblende, and are frequently granific in appearance. The typical rock is uniformly medium grained, light to dark gray in color, and consists of white feldspar and quartz, with brilliant black mica, and sometimes' small amounts of hornblende and garnet. The dark. minerals constitute about one-third of the rock, but the range in both directions is considerable, in one case giving rise to a biotite gneiss, in the other a granitic one. Origin, igneous.

\section{NATURE OF GRANITIC INTRUSIONS.}

The stages of the process whereby the granite masses of Connecticut have attained their present form are not altogether understood. It is, however, certain, as stated above, that the granites and granite gneisses have been revealed by the removal of overlying material; and if we assume erosion to have proceeded much farther and an additional thousand feet or so to have been removed from the rocks of the State we should find that, instead of the limited areas of granite gneiss and the few patches of granite now exposed, large areas of granite surrounded by gneisses and schists would exist.

There are several ways in which molten rock may find its way into strata already existing. It may be actually forced into other rocks in such a way as to crowd them apart or to lift them bodily. On the other hand, the molten mass which later becomes granite may work its way quietly into the surrounding rock, melting and assimilating the overlying strata. This is believed to be the method of intrusion by which the Connecticut granites were formed, and a mass like the Stony Creek granite gneiss or the Sterling granite gneiss is to be considered as merely surface portions of igneous intrusions which extend to great depth. It is quite likely, as previously stated, that some of these granite areas represent deep-seated portions of volcanoes from which at one time granitic lavas were poured out over the State. If such lava flows ever existed all traces of them have been removed by the erosion of thousands of feet of rock.

The Bristol and Collinsville granite gneisses represent another type of intrusion. In both these localities the Hoosac ("Hartland") 
schist is seen to lap up over the granitic rock, and the gneiss exposed shows evidence of being near the top of the original igneous mass.

\section{AGE OF THE CONNECTICUT GRANITES.}

It is generally supposed that the granites, and particularly the granite gneisses of Connecticut, date from the earliest geologic agesthat, in fact, they represent "parts of the original earth's crust," and this popular view coincides with the opinion expressed by geologists who have not studied the occurrence of these rocks in detail; but there is little to justify this view of the great age of most of the granitic rocks. With the possible exception of the Becket gneiss, no gneisses in Connecticut are regarded as of pre-Cambrian age, and the fact that the Sterling granite gneiss cuts metamorphosed Carboniferous sediments makes it unnecessary to aseribe a date earlier than the Carboniferous for most of the intrusives in the eastern part of the State.

The last of the great earth movements that gave the structure to the metamorphic rocks of Connecticut occurred, presumably, at the close of Carboniferous time, and though the structure of some of the granite gneisses indicates that they have been subjected to more than one series of earth movements, the structure of others may be explained on the theory that they have passed through only one period of metamorphism. For example, the gneissoid character of the Sterling granite gneiss is believed to date from post-Carboniferous time. If this hypothesis is correct, the igneous gneisses are, in part at least, younger than the schists with which they are associated. The granites which are little or not at all metamorphosed are probably of two periods, the first coincident with the movements which produced the gneissoid and schistose structure in the rocks, and the second at some later date. This second date of intrusion is proved by the fact that the massive granites have not been subjected to the pressure which produced the gneisses and that they cut into and through the granite gneisses. Occasionally, moreover, fragments of gneiss are included in the granite itself. The descriptions of Stony Creek granite gneiss and Westerly granite (pp. 81, 110, and 115) makes this relationship clear. The relative age of the various granites and gneisses may be stated as follows: The granite gneisses intruded into the ancient sediments are the oldest. The less metamorphosed granites come next; the pegmatites were formed at the same time as the granites or at a slightly later date, and dikes of granite were intruded after most of the pegmatites were formed. For instance, part of the granite quarried at Westerly is intrusive in pegmatites, granite and granite gneiss alike, and appears to be the latest formed rock in southeastern Connecticut. 


\section{STRUCTURE, ROCK VARIATIONS; WEATHERING, AND DISCOLORATION OF GRANITIC ROCKS.}

By T. NeLson DaLE.

\section{GENERAL STRUCTURE.}

The term "structure" embraces all the divisional planes that traverse the rock. These occur at intervals ranging from a microscopic distance to one measured by scores of feet, and either cross or, very rarely, give a course to the texture resulting from crystallization.

FLOW STRUCTURE.

Where two varieties of granite lie in contact the dividing line between them indicates the direction of their flow, for the same reason that the course of the flow of a stream would be shown by the demarcation between its water and that of a muddy tributary a little below their junction. In some places this direction is also indicated by streaks or sheets of mica scales parallel to the direction of the line between the granites. Such streaks, therefore, when alone are regarded as indicating flow structure. They may be inclined at all angles or be in horizontal undulations with axes pitching $10^{\circ}$ to $40^{\circ}$. In some Massachusetts and New Hampshire quarries the structure is parallel to the surface of the granite at its contact with overlying rocks, or surrounds in parallel bands the surface of large inclusions. Flow structure also is conspicuous in the granite of Milford, Mass., and in some of the quarries of Milford, N. H. The very local character of such structural features indicates that they are not due to pressure which affected the entire region, but that they originated while the granite masses were still plastic. A" granite that exhibits flow structure is called by some writers a flow gneiss.

\section{RTFT AND GRAIN.}

The rift in granite is a feature of considerable scientific interest and of much economic importance. It is an obscure microscopic foliation-either vertical, or very nearly so, or horizontal-along which the granite splits more easily than in any other direction. The grain is a foliation in a direction at right angles to this, along which the rock splits with a facility second only to that of the fracture along the rift. After a little experience an observer can detect the rift with the unaided eye, where it is marked.

The earliest mention of rift in geologic literature appears to be that by J. F. W. Charpentier ${ }^{1}$ in 1778 , who noticed that granite millstones which were cut with their largest diameter parallel to the rift were much more readily worn than those cut at right angles to it, that is, parallel to the "hard way." He attributed this to a parallel

\footnotetext{
${ }^{1}$ Mineralogische Geographie des chursächsischen Lande, 1778. See also his Beobachtungen iber die Lagerstaitte der. Erze, 1779.
} 
arrangement of the mineral particles. The next reference to rift is by Pötsch ${ }^{1}$ 1803, who described it in the granites of Lausitz, in Saxony. In 1833 it was referred to by Enys and Fox ${ }^{2}$ as characterizing the granites of Penrhyn, and was referred to in 1834 by De la Beche; ${ }^{3}$ also in 1855 by Adam Sedgwick, ${ }^{4}$ who attributed it to crystalline action at the time of consolidation. In 1860 C. F. Naumann ${ }^{5}$ attributed it either to local differences of cohesion or to an inner strain possibly related to the direction of original consolidation. In 1864 G. vom Rath ${ }^{6}$ described a diorite from Monte Adamello, in the Tyrol, without dominant rift, and observed that the rift course was, on the contrary, uniform in the granite of Monte Motterone (Baveno). In 1876 James D. Dana stated that "granite often has a direction of easiest fracture due to the fact that the feldspar crystals have approximately a uniform position in the rock bringing the cleavage planes into parallelism." 7 This is true in those places where the directions of flow structure and rift chance to coincide, and it may be true in some porphyritic granites that the porphyritic crystals are arranged with some reference to the rift, but that it is not the cause of rift is shown by the fact that the feldspar cleavages generally intersect the rift face at all angles. In 1879 Reyer $^{8}$ attributed rift to an original arrangement of particles by flowage. As rift in places crosses flow structure this explanation is also inadequate. In 1893 Carl C. Riiber, in a work on the granite industry of Norway ${ }^{\circ}$ described an augite syenite with inferior rift and grain, in which the cleavage planes of the individual feldspar crystals were parallel to the two cleavages, rift and grain, of the rock. Finally, in 1894, F. Zirkel, ${ }^{10}$ after reviewing the opinions of his predecessors, tentatively suggested that rift may be the result of conditions of strain brought about by pressure from one side only, which failed to find adequate relief in jointing.

The only available recent American data on this subject are furnished by Tarr, Whittle, and Finley. ${ }^{11}$

\footnotetext{
${ }^{1}$ Bemerkungen und Beobachtungen iber das Vorkommen des Granits in geschichtete Lagen, p. 140.

" liondon and Edinburgh Jhil. Mag., 3d ser., vol. 2, pp. 321-327.

" Researches in theoretical geology, and Report on the geology of Cornwall.

4 Trans. Geol. Soc. Loncion, 2d ser., vol. 3, pt. 3, p. 483.

"Lehrbuch der Geognosie, vol. 2, 2d ed., Leipzig, 1860, pp. 191-192.

${ }^{\circ}$ Beitrïge zur Kenntniss der eruptiven Gesteine der Alpen: Zeitschr. Deutsch. geol. Gesell., vol. 16, pp. 249-260.

${ }^{7}$ Manual of Geology, 2d ed., 1876, p. 628.

s Reyer, Ed., Tektonik der Granit Ergiisse von Neudeck und Carlsbad, etc. : Tahrb. K.-k. geol. Reichsanstalt, vol. 29, 1879 , p. 415.

- Norges granit industri : Norges Geol. undersögelse, Aarbog for 1893 , No. 12, p. 45.

${ }^{10}$ Lehrbuch der Petrographie, 2d ed., vol. 2, 1894, pp. 52-53, p. 415.

11 'Tarr, R. S., The phenomena of rifting in granite: Am. Jour. Sci., 3d ser., vol. 4.1, 1891, pp. 267-272, figs. 1-4; also Economic Geology of the United States, 1895, p. 124 . Whittle, Charles L., Rifting and grain in granite: Eng. and Min. Jour., vol. 70, 1900, p. 161, figs. 1. and 2. Finlay, G. I., The granite area of Barre, Vt. : Report of Vermont State Geologist, new ser., 1902, p. 54.
} 
Tarr presents four figures reproduced from drawings made from enlarged views of thin sections showing the rift in Cape Ann hornblende-biotite granite. These figures and his descriptions indicate that rift consists of microscopic faults, most of which meander across feldspar and quartz alike, although some go around the quartz particles rather than through them. In the feldspars rift generally follows the cleavage. These minute faults are lined with microscopic fragments of the mineral they traverse and some of them send off short, minute diagonal fractures on either side. In examining such a structure it is important to make sure that the grinding of the section has not in any way modified the original fractures. Tarr adds that at Cape Ann the rift does not traverse the "knots" or the basic dikes that cross the granite.

Whittle gives two sketches made from polished surfaces of a wellknown granite quarried by the Maine \& New Hampshire Granite Co. at Redstone, N. H. One of these sketches, made from a surface running at right angles to the rift, shows quartz and feldspar grains traversed by a generally parallel set of lines corresponding to the rift planes. The lines are more numerous in the feldspar than in the quartz grains. The other sketch, made from another specimen, shows besides the rift lines another less pronounced set intersecting these at right angles. This second set corresponds to the grain. Whittle calls attention to the fact that notwithstanding the marked rift and grain at this quarry the stone stood a compression test of 22,370 pounds to the square inch, and was therefore not appreciably weakened by the microscopic fractures. A visit made by the writer in 1906 to the quarry at Redstone, N. H., has corroborated Whittle's observations. ${ }^{1}$

Finlay, in describing the quartz of Barre granite, says: "The pronounced cracks which are seen to cross from one crystal to its neighbor, without interruption, are an indication of pressure phenomena in the magma after its consolidation. These cracks are notable as containing microscopic dendritic growths, which are analogous to the arborescent forms of $\mathrm{MnO}_{2}$, and possibly identical with them."

Another peculiarity of rift is that the angle of its inclination may at some places be modified by gravity. Thus, in some localities a block will split at one angle from the top, but at another from the side; or, again, at one angle where the mass of the block is at the right and at another where it is at the left of the line of fracture. Experienced granite workmen at Concord, N. H., and Quincy, Mass., report that at some places a block that would show a horizontal rift when split from one point of the compass (say the north) acquires an inclined rift if split from the south or the east or west. The cause of this is not apparent. There are also indications that a slight alter-

1 For details see Bull. U. S. Geol. Survey No. 354,1908 , p. 42. 
ation of the feldspars may improve the rift. Finally, as is well known to granite quarrymen, rift and grain are modified by temperature, the effect of winter cold in New England (frost?) being to intensify the rift and grain where they are weak.

Herrmann ${ }^{1}$ states that in Saxony the rift is parallel to the horizontal sheets or joints. That is true for short distances in the New England quarries, but where the rift is horizontal and the sheets curve it crosses the sheets, and of course where the rift is vertical it crosses them throughout. Exceptionally, in one. of the quarries at Quincy, Mass., a foreman reported to the writer a deflection of the rift in apparent relation to the increasing inclination of the sheets.

Rift and grain are not always pronounced. Either or both may be very feeble or may be absent.

At the Armbrust quarry, in Vinalhaven, Me., there is a horizontal rift confined to a 4-foot mass striking across the granite hillock.

The presence of fairly good rift or grain is an important economic factor in the granite industry, for it diminishes both the amount of labor in drilling for blasts and in splitting. .

That the rift is a factor in the crushing strength of granite is shown by the results of tests of Mount Waldo granite from Frankfort, Me., blocks of which when placed on the bed-that is, with pressure applied at right angles to the rift-showed an ultimate strength to the square inch of 31,782 to 32,635 pounds (average, $32,208)$, but when placed on the side-that is, with pressure applied parallel to the rift-showed an ultimate strength of from 29,183 to $.30,197$ pounds (average, 29,690). In the first test the first crack appeared in the block at a pressure of from 120,000 to 123,300 pounds (average, 121,650) and in the second test it appeared at one of 107,400 to 112,600 pounds (average, 110,000 pounds). ${ }^{2}$ Rift and grain in their relations to fluidal cavities are discussed on pages $42-47$ of Bulletin 354 .

SHEEIS.

The division of granite into "sheets" or "beds" by jointlike fractures which are variously curved or nearly horizontal, being generally parallel with the granite surface, attracted the attention of geologists long ago. In 1797 De Dolomieu, and shortly before that De Saussure, described granite sheet structure. ${ }^{3}$

In 1803 Pötsch ${ }^{4}$ published a paper on the subject. In 1841 Edward Hitchcock described what he termed the "Pseudo-stratification of

\footnotetext{
${ }^{1}$ Herrmann, O., Steinbruchindustrie und Steinbruchgeologie, Berlin, 1899, p. 109.

2 Reilly, J. W., Ordnance Rept., tests of materials, etc. (1900), 1901, p. 11.19. See also result of test of Concord granite, Bull. U. S. Geol. Survey No. 354, p. 147.

${ }^{3}$ Jour. des mines, vol. 7, No. 43, p. 426.

- Bemerkungen und Beobachtungen über das Vorkommen des Granits in geschichtete Lagen.
} 
granite," near Worcester and Fitchburg, Mass., as a concentric, onion-like structure generally conforming to the rock surface. ${ }^{1}$

In 1860 C. F. Naumann ${ }^{2}$ dealt with the subject in his textbook.

In $1863 \mathrm{~F}$. von Adrian described the structure in Bohemia and regarded it as the result of cooling. ${ }^{3}$

In 1879 Reyer ${ }^{4}$ described it from another part of Bohemia, and in 1894 Zirkel ${ }^{5}$ also treated the subject in his petrography.

Although this is the most striking feature in every granite quarry and largely makes the granite industry possible, there is a great diversity of opinion as to its cause. Whitney ${ }^{6}$ writes:

The curves are arranged strictly with reference to the surface of the masses of rock, showing clearly that they must hilve been produced by the contraction of the material while cooling or solidifying, and also giving very strongly the impression thit, in miny places, we see something of the original shape of the surface as it was when the grauitic mass assumed its present position.

Shaler, a few years later, ${ }^{7}$ attributed the sheet structure to expansion due to solar heat.

C. H. Hitcheock ${ }^{8}$ notices in New Hampshire granite "numerous joints, the planes of which correspond very nearly with the slope of the hill," but does not undertake to explain them.

Vogt ${ }^{9}$ states that the sheets in granites of southeastern Norway measure from 6 inches to 6 feet in thickness and dip from $8^{\circ}$ to $33^{\circ}$ on the sides of the mountains, toward the valleys, but that they are horizontal on top and approximately parallel to the surface. $\mathrm{He}$ shows that they are of preglacial origin, attributes them to the same cause that is postulated by Whitney for those in California, and regards them as parallel to the original surface of the granite masses.

Harris, ${ }^{10}$ referring to the English granite quarries, writes: "In every quarry we visited we found that the direction of the 'beds' approximately corresponded with the outline of the hill on which it was situated." He offers no explanation of the phenomenon, however.

J. J. Craw ford ${ }^{11}$ describes the sheet structure at granite quarries in Madera and Tulare counties, Cal., as consisting of "concentric layers

1 Final Report, Geology of Massachusetts, p. 683.

ะ Lehrbuch der Geognosie, p. 191.

3 Jahrb. K.-k. geol. Reichsanstalt, vol. 13, pp. 155-182:

4 Idem, vol. 29, 1879, p. 405.

5 Petrographie, vol. 2, p. 52.

"Whitney, J. D., Geology of California, vol. 1; 1865, Geology, p. 372; also pp. 227, 417, and figs. $49-54$.

${ }^{7}$ Shaler, N. S., Notes on the concentric structure of granitic rocks: Proc. Boston Soc. Nat. Hist., vol. 12, 1869, pp. 289-293.

$s$ Geology of New Hampshire, vol. 2, 1877, pp. 511-512 and plate opposite p. 158, showing sheet structure at the "Flume."

${ }^{\circ}$ Vogt, J. H. L., Sheets of granite and syenite in their relation to the present surface: Geol. Föreningens i Stockholm, Förhandl., 1879, No. 56, vol. 4, No. 14 ; also Nogle, Bemaerkninger om Granit: Christiania Videnskabsselsk. Förhandl., 1881, No. 9.

${ }^{10}$ Harris, George F., Granites and our granite industries, London, 1888.

1 Twelfth Rept. State Mineralogist of California, 1894, pp. 384-387 and 3 plates. 
conforming in a general way to the contour of the hills," but suggests no cause for them.

Herrmann, ${ }^{1}$ who made a special economic study of the granites of Saxony, writes:

Upon closer inspection it appears that the granite sheets are elongated lenses overlying one another, of which the upper one, as a rule, has its bulging part lying in the depression formed by the two underlying lenses where they come together.

Branner ${ }^{2}$ describes the exfoliation of the granitoid gneisses in Brazil, which he attributes only in part to changes of temperature. $\mathrm{He}$ calls attention to the fact that the linear expansion of a mass of gneiss 300 feet long at a depth of 15 feet from the surface under a surface temperature of $103^{\circ} \mathrm{F}$. would amount to only 0.072 inch; and he quotes the results of Forbes, Quetelet, and others to show that the annual change of temperature can penetrate rock only to a depth of 40 feet in temperate regions and still less in the Tropics.

Merrill ${ }^{3}$ describes Stone Mountain, in Georgia, as a boss of granite 2 miles long by $1 \frac{1}{2}$ miles wide and 650 feet high, which owes its form wholly to exfoliation parallel to preexisting lines of weakness. The mass appears to be made up of imbricated sheets of granite which he regards as the result of torsional strains. The bosslike form is incidental and consequent. Intermittent expansion and contraction from changes of temperature have so affected the sheets that bound the mass at the sides that they have found relief in expansion in an upward direction. These ruptured sheets are rarely more than 10 inches thick, but are 10 or 20 feet in diameter. ${ }^{4}$

Herrmann ${ }^{5}$ sums, up his conclusions on the subject substantially as follows: The so-called sheets are thin near the rock surface, generally only a few centimeters thick, but become gradually thicker with increasing depth. This downward increase in the thickness of the sheets is generally more rapid where the texture of the stone is coarser. The course of the sheets is not, as Vogt claims, parallel to the original surface of the consolidating rock. It is not governed by internal strains. The attitude of the sheets corresponds to the form of the present rock surface. The sheet structure is to be looked upon as the effect of the beginning and progress of weathering from the

\footnotetext{
1. Herrmann, O., Technische Verwerthung dei Lausltzer Granite: Zeitschr. prakt. Geologie, Nov., 1895, Heft 2, p. 435.

2 Branner, John C., Decomposition of rocks in Brazil : Bull. Geol. Soc. America, vol. 7, 1896 : Exfoliation, pp. 269-277, Temperature and exfoliation, pp. 285-292.

${ }^{3}$ Merrill, George P., Rocks, rock-weathering, and solls, 2d edition, 1906, p. 321.

${ }^{4}$ For description and representations of Stone Mountain see Merrill, as above, Pl. I; Purington, Chester W., Geological and topographical features of the region about Atlanta, Gi. : Am. Geologist, vol. 14, 1894, pp. 105-108 and Pl. IV; also Watson, Thomas L., Bull. Georgia Geol. Survey No. 9-A, 1902, p. 113, and Pls. I-VIII. See also description of another granite dome-Stone Mountain, in North Carolina-by Watson and Laney, in Bull. North Carolina Geol. Survey No. 2, 1906, PJ. XXV.

'Her'rmann, O., Steinbruchindustrie und Steinbruchgeologie, 1899, pp. 109-111,
} $97730^{\circ}-$ Bull. $484-11-3$ 
surface inward. These weathering cracks are determined by the form of the rock surface instead of that being determin'ed by them.

Turner ${ }^{1}$ calls attention to the sheet structure and exfoliation of Fairview Dome, in the Yosemite.

Gilbert ${ }^{2}$ shows that sheet structure occurs in synclinal as well as in anticlinal attitude-in other words, is parallel to hollows as well as hills-which he considers unfavorable to the theory that it is an original structure. He suggests that sheet structure may possibly be due to expansive stress consequent upon relief from compressive stress brought about by the removal of the mass into which the granite was intruded. Subordinately he notes that in the Sierras, at least, the dome structure and the parallel joint structure do not occur in the same place and that the former has resisted general erosion more successfully than the latter.

G. F. Becker, in a recent conversation with the writer, stated that he had found the granites and gneisses at the bottom of the Colorado Canyon both vertically and horizontally jointed. If these are true granites and are still in contact with the rocks into which they were intruded and show genuine sheet structure the phenomenon would conclusively prove that such structure may occur independently of solar heat and load.

S. F. Emmons similarly stated that in the Mosquito (Park) Range, in Colorado, the pre-Cambrian granite and schist are cut by horizontal joints to a depth of 50 feet below their contact with the overlying Cambrian, the-joints diminishing in number downward. The original load upon the granite here consisted of at least 10,000 feet of Paleozoic and between 5,000 and 6,000 feet of Cretaceous rocks. As the granite, however, was not intruded into Cambrian sediments it must have been exposed to atmospheric erosion before they were deposited. These horizontal joints may therefore have been related to solar temperature.

G. IK. Gilbert has recently studied the granite domes of Georgia and attributes their sheet structure to compressive strains. He finds that the granite in these domes ${ }^{3}$ is not naturally divided into plates, but that the outer parts of the granite-the parts nearest the surface-are in a condition of compressive strain, which results in slow exfoliation and which enables quarrymen, by meeans of carefully regulated blasts, to develop joints that run approximately paraillel to the surface, so that the granite is detached in sheets. As thèse sheets are divided into blocks in the process of quarrying, the blocks expand horizontally as they are released from the general mass. In

1 Turner, H. W., The Pleistocene geology of the south-central Sierra Nevada, with espeeial reference to the origin of the Yosemite Valley: Ṗroc. Cảlifoinia Acád. Sci., 3d ser., Geology, vol. 1, No. 9, 1900 ; Formation of domes, pp. 312-3i5, añd Pl. XXXXvir.

2 Domes and dome structure of the high Sierras: Bull. Géol. Sòc. Am.; vól. 15, pp. $29-36$, and pl. 3, 1904.

${ }^{3}$ Letters to writer, dated May 4 and June 11, 1906. 
these granitic domes parting planes also develop naturally within a few inches of the surface, and the expansive force is there so great as to induce conspicuous buckling in the thin sheets thus formed. The jar of blasting precipitates this sheeting action, so that several of the domes at which quarrying is in progress show long lines of freshly formed disrupted arches. Mr. Gilbert found that the horizontal elongation, or rather the elongation coincident approximately with the contour of the dome surface, amounted, by one measurement, to three-fourths inch in a length of 40 feet.

The effects of compressive strain on granite were observed by the writer in 1907 at a quarry at the west foot of Black Mountain, a domelike mass in West Dummerston, near Brattleboro, Vt. New thin sheets have this been formed and one of the sheet fractures opened $3 \frac{1}{2}$.inches.

The artificial production of sheets in granite, as practiced at Bangalore, in southern India, shows similar phenomena. It is described by $\mathrm{H}$. Warth ${ }^{1}$ in substance as follows: At the surface there is a horizontal sheet of rather weathered rock 4 feet thick; below this lies a sheet of fresh rock 3 feet thick, but below this lies fresh rock without split. These sheets "are probably due to the variations of temperature, daily and seasonal.". By means of wood fires plates 60 by 40 feet by 6 inches in thickness are detached in one piece. A line of fire 7 feet long is gradually elongated and moved over the granite. The effect of the fire is tested by hammering the granite in front of it, and then the fire is moved forward. The maximum length of the arc of fire is 25 feet. The burning lasts eight hours; the line of fire is advanced 6 feet per hour. The area passed over by line of fire is 460 square feet. The amount of wood used is 15 hundredweight. The average thickness of stone is 5 inches and its specific gravity is 2.62. These data show that 30 pounds of stone are quarried with 1 pound of wood. Some plates are taken out in inclined position. The action of fire is independent of the original surface of rock; also of the direction of lamination (the granite is gneissose) and of veins. The uniformity in the thickness of the sheets is attributed to the regulating influence of preexisting cracks.

Van Hise, in his treatise on metamorphism, ${ }^{2}$ is inclined to attribute sheet structure to solar temperature.

Sheet structure, as exposed at the Maine quarries, is described in Bulletin 313, on pages $33-35$, and is illustrated in Plates II, $B$, III, V, VI, and IX, $A$, of that bulletin. Its general character is illustrated in Plates III, $A$, and V, $A$, of Bulletin 354 ; its relation to surface form in Plate VII, $A$, and to overlying rocks in Plates VI, $A$, and IX, $A$, of that bulletin. 
The observations as to sheet structure, made at over 100 granite quarries in New England are here summarized:

1. There is a general parallelism between the sheets and the rock surface, resulting in a wavelike joint structure and surface over large areas.

2. The sheets increase in thickness more or less gradually downward.

3. The sheets are generally lenses, though in some places their form is obscure. Their thick and thin parts alternate vertically with one another. The joints that separate these superposed lenses therefore undulate in such a way that only every other set is parallel.

4. On Crotch Island, Maine, the sheet structure extends to a depth of at least 140 feet from the surface, and at Quincy to 175 feet.

5 . There are indications here and there that the granite is under compressive strain, which tends to form vertical fissures or to expand the sheets horizontally so as to fill up small artificial fissures or to extend the sheet partings horizontally.

The observations made in Europe and in this country, taken in connection with the various inferences geologists have drawn from them, indicate that sheet or "onion" structure in granite rocks is due to the following possible causes:

1. To expansion caused by solar heat after the exposure of the granite by erosion.

2. To contraction in the cooling of the granite while it was still under its load of sedimentary beds, the sheets being therefore approximately parallel to the original contact surface of the intrusive.

3. To expansive stress or tensile strain brought about by the diminution of the compressive stress in consequence of the removal of the overlying material.

4. To concentric weathering due to original texture or mineral composition. This action would be chiefly chemical and would be aided by vertical joints and by any superficial cracks due to expansion and contraction under changes of temperature.

5. To compressive strain akin to that which has operated in the folding of sedimentary beds.

6 . To the cause named under 1 at the surface, but to the cause named under 5 lower down.

These propositions will be considered in the order given:

1. Solar heat may produce a certain amount of exfoliation in thin sheets at the surface, as is proved experimentally in the fire method of granite quarrying in India (p. 33), but as it penetrates only to a depth of 40 feet and as sheet structure is known to occur on Crotch Island, Me., at a depth of 140 feet and at Quincy, Mass., at a depth of 175 feet, it is quite inadequate to account for sheets that are 20 to 30 feet thick and 100 to 175 feet below the surface. 
2. In view of the load under which granite was generally formed, and the gradual rate at which, therefore, it probably cooled, which is also indicated by the general coarseness of its texture, it is very improbable that the temperature at its contact surface and the temperature at depths 100 or 200 feet below could have so greatly differed as to bring about such a system of joints by contraction.

3. As Gilbert states, in suggesting the theory of fracture by relief of tensile strain through the erosion of overlying masses, we have no distinct knowledge of it. It is a possible explanation.

4. Careful inspection of the rock on both sides of the sheet joints fails to show any difference in texture or mineral composition. The sheet structure traverses both rift and flow structure, and it would be possible to procure specimens showing a sheet joint traversing a single crystal of feldspar. Whatever chemical action has taken place along the sheet joints is of secondary character. Acid waters may have gained access to the joint, but have not caused it.

5. The condition of strain described by Merrill and Gilbert as existing in the granite domes of Georgia and by Niles and Emerson in the gneiss at Monson, Mass., ${ }^{1}$ and by the writer at West Dummerston, Vt., and occurring to a lesser extent in some Maine quarries, shows that granite and gneiss are in places still under compressive strain. Another instance occurs at the quarry of the New England Granite Works, at Concord, N. H. The foreman at this quarry was in the habit of calling certain sheets, marked by the absence of discoloration, "strain sheets," to distinguish them from the others. At one place a northwest-southeast compressive strain had actually extended the strain sheet about 5 feet, and also caused a vertical fracture that extended over 15 feet diagonally from the north-south working face to a point on a vertical east-west channel 5 feet back of the face, closing up the channel to half its original width. Evidences of compressive strain were also noted at Quincy and Rockport, Mass., and at Westerly, R. I., and have also been observed by the writer in some of the Barre and Woodbury, Vt., quarries. The practicability of developing sheet structure by the use of explosives and compressed air, as is done in some of the North Carolina granite quarries, shows that the rock is under a compressive strain there. ${ }^{2}$

-All these observations bring this theory within the domain of inductive science. If sheet structure is due to compressive strain, it is due to such a strain as would produce a series of undulating fractures extending entirely across a granite mass several miles in diam-

\footnotetext{
1 Niles, W. H., Some interesting phenomena observed in quarrying: Proc. Boston Soc. Nat. Fist., vol. 14, 1872, pp. 80-87, and vol. 16, 1874, pp. 41-43. Emerson, B. K., Geology of Old lTampshire County, Mass.: Mon. U. S. Geol. Survey, vol. 29, 1898, pp. 63-65.

2 Watson, T. T., and Laney, F. B., 'The building and srnamental stones of North CaroIlna : Bull. North Carolina Geol. Survey No. 2, 1906, pp. 157-160.
} 
eter and to a depth, as far as observed, of 175 feet from the rock surface.

6. In view of the undoubted sheeting effect of expansion under solar heat within a short distance of the surface and of the fact that some of the sheets near the surface measure but a. few inches in thickness, it is quite possible that very thin surface sheets have originated in this way; but in view of what was stated under heading 5 it seems probable that compressive strain is the main factor in producing massive sheets. At the surface both causes may have cooperated. The progressive thickness of the sheets downward indicates that the operation of this strain is evidently also dependent upon distance either from the present surface or from a former surface or contact.

According to this view sheet structure may be said to exert a controlling influence upon surface forms, yet it seems quite admissible that granite domes as conspicuous as Stone Mountain, in Georgia, and Fairview Dome, in California, notwithstanding all the exfoliation that has taken place on them or the erosion they may have suffered, may. still retain some degree of parallelism between their present form and the original contour of the granitic intrusions of which they are parts. This may be true, also, of the granite hills of Mount Desert.

The probability being admitted that the general parallelism between the present surface and the sheet structure is the result of erosion that followed the sheeting, the question still remains, What has determined the form and location of the domes? These may possibly be referred to major arches (anticlines) in the folds of the stratified rocks which originally overlay the granite. The crustal movement that produced these folds may also have brought about the intrusion of the material that formed the domes beneath them.

Although the sheet structure and the rock surface are very generally parallel, they are not universally so.

Sheet structure in granite so much resembles the structure of folded stratified rocks that underground water circulates in practically the same way along the fracture planes of one and bedding planes of the other. The exudation of water along sheet joints on vertical rock faces is seen in many of the Maine quarries, and also in some Rockport and Niantic quarries. (See Bulletin 313, Pl. VI, B, and Bulletin 354, Pl. V, A, and IX, A.)

\section{JOINTS.}

Herrmann ${ }^{1}$ divides joints in two groups-joints formed by lateral compression, whose distances from one another are related to the

${ }^{1}$ Herrmąnn, O., Stentbruchindustrie und Steinbruchgeologie, 1899, p. 103. 
coarsenesss of the rock texture, and joints due to expansion, some of which are parted and filled with calcite, quartz, pegmatite, or volcanic rock. That many joints are due to compressive or torsional strain, and that every such strain resolves itself into two components, resulting in two sets of joints that intersect at an angle of about $90^{\circ}$, each forming an angle of about $45^{\circ}$ with the direction of the strain, are facts now generally recognized. Crosby ${ }^{1}$ has suggested that torsional strains may have been supplemented by vibratory ones in causing joints. Becker, ${ }^{2}$ in a recent paper, shows that four or even more than four systems of joints may be due to a single force. $\mathrm{He}$ also shows that subsequent strain on a region thus jointed would tend to produce motion along the previously formed joints rather than a new system of jointing. It is conceivable that if a region had been jointed and afterwards subjected to a tensile strain, some of its joints might be parted, and if they were very deep the openings might become filled with volcanic matter from below, or, if not, with matter from above, infiltrated from overlying rocks. That motion has occurred along some of the joints in the quarries is evident from the polished and striated surfaces of the joints as well as from the faulting of the sheets.

Joints are exceptionally as curved "as the side of a ship." (See Bulletin 313, Pl. VI, B.)

Possibly related to such curved joints are what some New England quarrymen term "toe nails." These joints strike with the sheets, but extend only from one sheet surface to the next, and have a curve which sharply intersects that of the sheet structure. Such joints seem to be due to a strain different from that which produced the sheets. They were noted at Quincy, Westerly, and Milford, N. H.

The spacing of the joints varies considerably, ranging from 1 foot to 500 feet, but usually from 10 to 50 feet.

In some localities the jointing is very irregular. The granite is broken up into various polygons, which at the surface, where weathering has made inroads, resemble bowlders. Quarries opened in such places are called bowlder quarries. Another sort of irregularity in joint consists in their discontinuity or intermittence, their strike and dip for the short spaces in which they occur being uniform.

\section{FIEADINGS.}

In some places joints occur within intervals so short as to break up the rock into useless blocks. For a space of 5 to 50 feet the joints may be from 6 inches to 3 feet apart. A group of close joints is

\footnotetext{
1 Crosby. W. 0., The origin of parallel and intersecting joints: Am. Geologist, vol. 12. 1893, pp. 368-375.

${ }^{2}$ Becker, George F., Simultaneous joints: Proc. Washington Acad. Sci., vol. 7, July, 1905, pp. 267-275, Pl. XIII.
} 
called by quarrymen a "heading," possibly because, when practicable, such a mass is left as the head or wall of the quarry. (See Bulletin 313 , Pls. VIII, $A$, and IX, $B$, also Bulletin 354 , Pl. VI, B.) Headings afford ample ingress for surface water, and consequently the granite within a heading is generally badly stained, if not decomposed. This will be referred to more fully under the heading "Decomposition."

An interesting feature of both headings and joints shown in some of the deeper quarries at Quincy, Mass., is their vertical discontinuity. A heading occurring at the surface may disappear below, or a heading may abruptly appear a hundred feet below the surface and continue downward.

Headings are not easily accounted for. They may be produced by vibratory strains that recur at intervals of time. If they are so caused, the character of the fractures in some headings indicate that the strains are very complex.

\section{FAULTS.}

The polished and grooved faces ("slickensides") observed on many of the joints at the quarries show that faulting has occurred along them. The discontinuity of the sheets at some of the joints, causing, where the joints are slightly inclined, what quarrymen call "toeing in," may probably be attributed to faulting. This supposition assumes, of course, that the sheet structure was formed prior to the jointing. Faulting occurs also along sheets, displacing vertical flow structure, or vertical dikes. (See Bulletin 313, Pl. VIII, B.) It may occur along one of two intersecting dikes, displacing the other, as at the Deep Pit on Cape Ann. (See Bulletin 354, Pl. V, B.)

In some quarries the granite near the surface acquires a marked foliation, which appears to be parallel to the sheet structure, and in places to the rift. This foliation is known by quarrymen as "shakes." It occurs both at the top and at the bottom of the sheet, through a maximum thickness of 6 inches. It is coextensive with the discoloration known as "sap" and occurs at many places near vertical joints. Under the microscope this structure proves to consist of minute, nearly parallel fissures, of no great continuity, which traverse the mineral particles and which in the thin section examined are especially conspicuous in the quartz and the mica. The distance between these fissures measures from a tenth to a half a millimeter, or from one two-hundred-and-fiftieth to one-fiftieth inch. The parallelism, both to the sheets and the "sap," and its relation to the vertical joints indicate that the structure may be due to the freezing of surface water which has found its way to the sheets through the vertical joints and has entered the rift fissures. 
The writer's attention was called to a similar structure in a quarry at Milford, N. H., consisting of short parallel fractures along the rift, from one-half inch to 2 inches apart, having no apparent connection with joints or discoloration. This is probably due to strain affecting part of the granite mass and producing miniature sheet structure.

\section{SUBJOIN'TS.}

Careful inspection shows that the joint structure in granites does not everywhere consist of a simple fracture, but that it is at many places complex. Minute fractures branch off from the joint at an acute or right angle and penetrate the rock a few inches, or the rock for a few inches on either side of the joint is traversed by microscopic fissures that are roughly parallel to it. All such structural features may properly be called subjoints.

Woodworth has studied analogous and related structures in various rocks and has described them as "joint fringe" and "feather fractures." 1

\section{ROCK VARIATIONS.}

Under the term " rock variations" are grouped all those variations from typical granite that are due to injection, segregation, infiltration, inclusion, and steam cavities.

\section{DIKES (GRANITIC).}

The granitic dikes in the quarries are of three kinds: Extremely fine grained granite (aplite), very coarse grained granite (pegmatite), and fine or medium grained granite.

In thickness they range from a fraction of an inch to over 20 feet, but generally from 2 inches to 2 feet.

Aplite differs from ordinary granite by the greater fineness of its texture and its scant content of mica. It is known by quarrymen as "salt horse" or "white horse."

Aplite dikes are supposed to have originated in the same deepseated molten mass as the granite they traverse, but they represent a later stage of igneous activity. The fissures they fill were the result of various tensional strains or contractions, possibly consequent upon the cooling of the granite.

In color these dikes vary from bluish gray to light and dark reddish. The texture of some aplites is so fine that the mineral particles can not be distinguished with the unaided eye; that of others is so coarse that the feldspar and mica may be thus detected. Under the

1 Woodworth, J. B., On the fracture system of joints, with remarks on certain great fractures : Proc. Boston Soc. Nat. Hist., vol. 27, 1896, pp. 169-173, pls. 1, 2. 
microscope the dimensions of the particles range from 0.05 to 0.75 $\mathrm{mm}$., the average being about $0.16 \mathrm{~mm}$. for the finer ones and 0.50 $\mathrm{mm}$. for the coarser ones. Some aplites have a porphyritic texture.

Most aplites contain a slightly higher percentage of silica than granite. Five analyses of aplites from the Far West made at the laboratory of the United States Geological Survey ${ }^{1}$ show a range of silica from 71.62 to 76.03 per cent and an average of 74.08 , which is near the maximum of silica for granite generally.

Pegmatite lies at the other extreme. Its mineral constituents range generally from one-half to 1 foot or even several feet in diameter. It is reported that the crystals in some pegmatite dikes measure from 10 to 30 feet in length by 1 to 3 feet in width. The chief minerals in pegmatite dikes are the same as in granite, but they occur in different though varying proportions. With these minerals are commonly associated tourmaline, garnet, beryl, etc. Chemically these dikes generally contain more silica than the granite. Dikes of pegmatite are, as a rule, more irregular in width than those of aplite. They generally range in thickness from 1 inch to 10 feet.

The origin of pegmatite has been much discussed both in Europe and in this country. ${ }^{2}$ The coarseness of its constituent minerals indicates slow crystallization, and the irregularity of the dikes shows tensional rather than torsional strain. The banding of some pegmatite dikes and the isolated lenticular character of others indicate that the dikes were filled from heated solution, and many of them differ in no respect from dikes of igneous origin except by the coarseness of their texture. For these reasons it is thought that pegmatite dikes in granite have been formed in openings and frssures that were due, possibly, to contraction while the granite was still hot and that some of these openings were filled with matter in a state of both molten plasticity and solution under pressure, and others by heated solutions that gathered matter from the adjacent granite. Howsoever derived, this dike material crystallized very slowly.

Granite.-Finally, there are dikes that differ from all those just described, formed simply of fine or medium-grained granite.

VEINS.

Quartz veins occur rarely in the Maine granite quarries (see Bulletin 313, p. 46) and at but few of the other New England quarries. Some of these seem to be clearly of pegmatitic origin.

${ }^{1}$ Bull. U. S. Geol. Survey No. 148, 1897, pp. 124, 150, 206, 219.

2 The principal American writings on the subject are: Williams, G. H., The general relation of the granitic rocks in the middle Atlantic Piedmont Plateau : Fifteenth Ann. Rept. U. S. Geol. Survey, 1895, pp. 675-684 ; Crosby, W. O., and Fuller, M. L., Origin of pegmatite: Tech. Quart., vol. 9, 1896, pp. 326-356; Am. Geologist, vol. 19, 1897, pp. 147-180 ; Van Hise, C. R., A treatise on metamorphism : Mon. U. S. Geol. Survey, vol. 47, 1904, pp. 720-728; Bastin, E. S., Geology of the pegmatites and associated rocks of Maine, including feldspar, quartz, mica, and gem deposits : Bull. U. S. Geol. Survey No. 445, 1911. 


\section{DIKES (BASIC).}

Dikes of dark-greenish or black, hard and dense rock (diabase, rarely basalt) are of very common occurrence in the Maine and Massachusetts quarries. Some of them are represented in Bulletin 354 , Plate V, $A$ and $B$.

Most of these dikes are so firmly welded to the granite that hand specimens that are one-half granite and one-half diabase are readily obtained. Thin sections of the glassy rims of dikes show that the dike sent out microscopic branches for short distances into the granite, in places surrounding some of its quartz particles.

The geologic age of these dikes has not been precisely determined. They are considerably more recent than the granite they traverse or the dikes of aplite and pegmatite which traverse the granite.

The diabase dikes are the result of an earth movement that either opened previously formed joints or made new ones deep enough to be injected" with volcanic material. How far this may have penetrated the rocks which overlay the granite, or whether it overflowed at their surface, can not even be conjectured.

At the granite quarries, wherever this course is possible, the dikes and the headings are left to form the bounding walls of the excavations.

\section{SEGREGATTONS (KNOTS).}

Quarrymen know too well that granite is commonly disfigured by gray or black "knots" of circular or oval irregular curved outline, ranging in diameter from half an inch to 3 feet and exceptionally even 10 feet. These were studied by geologists long ago. ${ }^{1}$ They are finer grained than the granite in which they occur, contain nearly 10 per cent less silica, much more black mica or hornblende (which accounts for their darkness), and a little more soda-lime feldspar, and their specific gravity is about 0.09 per cent higher.

Plate V, $A$, of Bulletin 313 shows twelve small knots in one of the Sullivan quarries, and on pages 49 and 50 of that bulletin thin sections of knots from the Maine quarries are described. Several varieties from the Quincy quarries are described on page 95 of Bulletin 354 and one of exceptional character from Rockport on pages $64 ; 125$, of the same bulletin.

In none of the knots is there a definite boundary separating them from the granite, excepting such as is caused by the change in the proportionate abundance of the darker minerals. The cause of knots

1 Phillips, J. A., On concretionary patches and fragments of other rocks contained in granite: Quart. Jour. Geol. Soc. London, vol. 36, 1880, pp. 1-22, Pl. I. Merrill, G. P., On the black nodules or so-called inclusions in the Maine granite. Proc. U. S. Nat. Mus., vol. 6, 1883, pp. 137-141. Grimsley, G. F., Basic segregations: The granites of Cecil County in northeastern Maryland; Jour. Am. Soc. Nat. Hist., Apr. and July, 1894. Daly, Reginald A., Basic segregations: The geology of Ascutney Mountain, Vermont: Bull. U. S. Geol. Survey No. 209, 1903, p. 164. 
is not perfectly understood. They are collections (segregations) generally of the darker, heavier, iron-magnesia minerals that took place while the rock was in a plastic state.

\section{GEODES.}

Small cavities lined with crystals occur in granite. They have been found by the writer at the Jonesboro and Marshfield quarries in Maine and at Redstone, N. H. Their greatest diameter was about 12 inches, and the lining crystals were quartz, more or less amethystine, and feldspar. These were commonly coated with epidote, chlorite, and calcite, the calcite generally in very obtuse rhombohedra up to half an inch across. A geode at Redstone is surrounded by a band of aplite.

Such cavities are attributed to bubbles of steam or gas that were in the rock while it was in a molten state, which gave room for the growth of crystals and later became filled with epidote and calcite.

\section{INCLUSIONS.}

Not to be confounded with "knots," although some of them are equally dark and occur near them, are irregular or angular particles of various schistose rocks which the granite incorporated into itself during its intrusion. They can usually be distinguished from the knots by their different microscopic structure. In the Maine quarries they range from an inch to 40 feet in length. Part of the jagged edge of the lower part of a large schist inclusion in granite at Freeport, Me., is shown in Plate VII, $B$, of Bulletin 313; specimens from schist inclusions in Vermont granite are shown in Plate II, $B$, of Bulletin 404.

\section{DISCOLORATION.}

Rusty (limonite) staining along the upper and lower parts of the sheets and also along the joints and headings is common in granite quarries, although some quarries are almost entirely free from it. The zone of discoloration along the sheets in the Maine quarries is from one-half to 12 inches, exceptionally even 18 inches, wide on each side of the sheet parting. Its width, however, decreases gradually from the surface sheets downward. In places the sap consists of two parts-an outer dark brownish zone from three-fourths to $1 \frac{1}{2}$ inches wide and an inner more yellowish zone from one-fourth to one-half inch wide. Generally, however, the discoloration diminishes gradually from without inward. In some quarries there seems to be a connection between the "shake" structure and the discoloration, since these are coextensive.

When the stone is intended for facing or trimming buildings the presence of sap is a serious matter, as the stained edge of each block must be split off, which adds somewhat to the cost of production. 
This discoloration has been supposed to be always due to the oxidiction of the ferruginous minerals of the granite, biotite, hornblende, magnetite, and pyrite, but the Maine thin sections examined by the writer do not bear out this theory. (See Bulletin 313, p. 53 and fig. 2.)

These observations lead to the inference that the discoloration called "sap" is; in some Maine granites, not due chiefly to the oxidation of the ferruginous minerals of the granite by "underground water," but chiefly to the deposition of limonite by ferruginous surface water. The water descended along the vertical joints and then flowed along the sheet partings and permeated the rock above and below them. Whether the postglacial submergence of the Maine coast had anything to do with the discoloration is not clear.

Another kind of discoloration, which is even more serious in its consequences, appears on fresh faces of granite, either in the quarry or after its removal. This consists of sporadic rusty stains from half an inch to an inch in diameter, arising from the oxidation of minute particles of some undetermined ferruginous mineral, possibly allanite. Such stains generally, however, arise from pyrite particles or crystals.

Daly ${ }^{1}$ describes a bluish-gray syenite from Windsor, Vt. (feldspar, quartz, hornblende, augite, biotite), that after 24 hours' exposure assumes a greenish tinge, which eventually becomes more or less brownish. He has demonstrated by experiment with oxygen that this change is due to the oxidation of minute blackish granules of ferrous oxide within the feldspar, giving a yellow which, in combination with the original bluish tint of the feldspar, produces a green. The large columns of the library of Columbia University, in New York, are made of this rock.

Another kind of discoloration occurs on either side of diabase or basalt dikes, caused mainly by various alterations of the feldspars and their consequent change in shade or color. (See Bulletin 313, p. 91; and the examples at Rockport, Mass., and Milford, N: H., described on pp. 125 and 163 of Bulletin 354.) Discoloration is thus of five kinds - that due to the infiltration of ferruginous water, that due to the oxidation of the generally disseminated ferruginous minerals (biotite, hornblende, and magnetite) by nonferruginous water, that due to the oxidation of sporadic ferruginous minerals, that arising from the oxidation of ferrous oxide within the feldspars, and that due directly or indirectly to dikes and veins.

\section{DECOMPOSITION.}

Notwithstanding the strength and durability of granite, it is liable, under certain conditions and in the course of long time, to decompose

\footnotetext{
1 Daly, Reginald A., The geology of Ascutney Mountain, Vermont: Bull. U. S. Geol. Survey No. 200, 1903, pp. 51-53.
} 
into a clayey sand. This is the result of its physical, mineralogical, and chemical constitution and properties. One of the most striking illustrations of this is the occurrence in some of the Maine quarries of "beds" of sand or decomposed granite within the fresh granite, either between the sheets away from headings or within the headings and along or across the sheets. Thus at the Palmer quarry, in Vinalhaven, 20 feet below the surface in the face of the quarry, there is a bed of granite sand 18 inches thick between two sheets, which at that point dip about $10^{\circ}$ into the hill. On the southeast side of the Longfellow quarry, near Hallowell, some of the sheets within a wide heading include granite sand beds that are about 10 inches thick. At the Shattuck Mountain quarry, near Redbeach, a 6-foot heading includes a vertical layer of granite sand 8 inches thick. Specimens taken from these various sand beds show that the disintegration begins with microscopic fractures; in some cases the enlarged rift cracks, producing the "shake" structure described on page 38, and is followed by more or less kaolinization of the feldspars. This process consists in the loss of alkali and the taking up of water, resulting in the passing of the feldspar into a white clay (kaolin).

The joint and sheet structure affords ingress to surface water, containing its usual percentage of carbonic acid, and the "rift" or "shake" structure facilitates the kaolinization of the feldspar on either side of the sheet parting by this water. As the feldspars pass into clay the rock crumbles into sand consisting of quartz, mica, and kaolin, and of feldspar in various stages of kaolinization. In some places within the range and depth of frost a large part of this work may have been done by frost alone. The sand would there be mainly the product of the "shake" structure.

In regions which have not been swept by a continental glacier any granite mass would be covered with the products of the decomposition of its own surface. In the Tropics the abundant rainfall and the organic acids from a luxuriant vegetation materially hasten the decomposition, and granitic rocks in such regions are for these reasons commonly covered.with many feet of sand and soil. ${ }^{1}$

The incipient stage of weathering may be observed in any longexposed granite ledge in the milky whiteness of the feldspars. This change usually attacks the soda-lime feldspars first. The black mica, owing to its content of iron oxide, is also liable to early decomposition. The process of weathering, as it affects the rock as a whole, involves the following chemical changes: A loss of lime, magnesia, potash, and soda; a gain of water, and a relative gain of silica, alumina, and iron oxide-that is, relative to the reduced weight of the

1 Branner, John C., Decomposition of rocks in Brazil : Bull. Geol. Soc. America, vol. 7, 1896 ; Exfoliation, p. 31. 
weathered rock. The subject of weathering of granite is fully treated in the writings of Merrill, Keyes, and Watson. ${ }^{1}$

The changes in granite after it has entered into buildings or other constructions are less marked than those in the natural rock, because the blocks are not then traversed by anything analogous to sheet and joint structure, and also because the years of historic time are few compared to those of geologic time. Much has been written on the decay of granite in monuments and buildings." Such decay is mainly attributable to microscopic fissures produced by the unequal and repeated expansion and contraction of the different minerals of the granite under changes of solar temperature. In countries where the winter temperature is very low the action of frost within such fissures powerfully assists the process of disintegration. Thus the obelisk now in New York suffered more from three years' exposure to our climate than it had during over three thousand four hundred years in Egypt, although the fissures along which frost operated were started long before it reached this country. A minor factor in decay is the chemical action of water along fissures. ${ }^{3}$

It is supposed that these causes of decay operate more effectively in coarse granites than in fine ones. Merrill points out that a sawn or properly prepared polished surface resists weathering more effectively than a cut or hammered one, as the latter is full of minute fractures, parallel to the surface, produced by impact, which facilitate scaling.

\section{GEOLOGIC OBSERVATIONS AT THE QUARRIES.}

\section{By 'T. Nelson Dale.}

The geological observations made in visiting the quarries of the State are recorded in detail in the quarry descriptions in Part II. Although the exposures at many of the quarries are of considerable scientific interest, yet the quarries which combine more interesting features are those of Stony Creek and Hoadly Point, in Branford; the Millstone and Waterford quarries, in Waterford; the Borough quarry, in Torrington; and the quarry on Mine Hill, in Roxbury.

\footnotetext{
1 Merrill, G. P., Disintegration of the granite rocks of the District of Columbia: Bull. Geol. Soc. America, vol. 6, p. 321, 1895; also A treatise on rocks, rock-weathering, and soils, New York, 1897, pp. 206-214, 236, 244, 245, 257. Keyes, Charles R., The origin and relations of central Maryland granites : Fifteenth Ann. Rept. U. S. Geol. Survey, 1895, p. 725, and pls. 42-45. See also Proc. Iowa Acad. Sci., vol. 1, pt. 3, pp. 22-24, and vol. 2, pp. 27-31, Pls. II-IV, 1895. Watson, Thomas L., A prelfminary report on a part of the granites and gneisses of Georgia, 1902, pp. 299, 300, 308, 329, 331, 333.

a Julien, A. A., The Durability of building stones in New York City: Tenth Census, vol. 10, 1884 ; Granite, pp. 370-371. Merrill, Geo. P., Physical, chemical, and economic properties of bullding stones: Maryland Geol. Survey, vol. 2, 1898; Granite, pp. 92-94. Also Merrill's Stones for building and decoration, 3d ed., 1908; Weathering of granite, pp. $434,435$.

3.Julien, A. A., A study of the New York obelisk as a decayed bowlder: Annals New York Acad. Scl., vol. 8, 1893, pp. $93-166$.
} 
The more important observations made at the quarries are grouped or summarized in the following paragraphs:

\section{MICROSTRUCTURE.}

Attention has been called in another bulletin ${ }^{1}$ to the fact that when a thin section of granite is made at right angles to the rift many of the microscopic cavities in the quartz particles are found to be arranged in parallel sheets, and that where the rift is well developed rift cracks will be observed parallel to or coinciding with these sheets of cavities. As noted in the microscopic descriptions of Part II of this bulletin, this arrangement of cavities in sheets was observed in the mica diorite gneiss of Greenwich and of the Torrington Borough quarry; in the granite gneiss of the Bridgeport Jail quarry, and of the Norwalk, Ansonia, Norfolk, Roxbury, Benvenue, Stony Creek, Hoadly Point, Leete Island, Sachem Head, Selden Neck, and Flat Rock and Goos quarries in Waterford; in the quartz monzonite of Mystic and Niantic; and also in the granite of Pawcatuck, the flow gneiss of Masons Island, the pegmatite of Lyme village, and the aplite of the Ritch quarry, at Greenwich. Rift cracks were observed parallel to or coinciding with such sheets of cavities in the granite gneiss of Roxbury and of Joshua Rock in Lyme; in that cut by the pegmatite of the MacCurdy quarry, at Lyme village; in the elongated porphyritic gneiss of Bolton, near the Glastonbury line; in the gneiss of the Michiel quarry, near Torrington; in the quartz monzonite of Center Groton; and in quartz monzonite and pegmatite of the Torrington Borough quarry.

Rift in the gneisses was always found parallel to the foliation except in the gneiss of Selden Neck, in Lyme, in which it is parallel to the long axes of the biotite lenses and at right angles to the foliation, and again in the banded gneiss of the McIntosh quarry, near Groton, where the rift is also transverse to the foliation, both rift and grain fractures being smoother than those along the banding.

In the fine-grained quartz monzonite of the Waterford quarry (p. 113) the long axes of the slender biotite scales, few of which are over 0.1 inch long, are parallel to the rift, as they probably are in some of the other quartz monzonites of the State. Of interest in this connection is a statement made by a Cornish granite quarryman, $\mathrm{Mr}$. W. B. Stephens, now superintendent of the Rockside quarry in Roxbury, to the effect that in the granite quarried by John Freeman \& Sons at Colcerrow, in Cornwall, the feldspars, which are about 2 by 0.5 inches, are arranged with their long axes parallel to the rift and the short axes parallel to the hardway. Prof. J. D. Dana ${ }^{2}$ attributed

1 Bull. U. S. Geol. Survey No. 354, 1908, pp. 42-47, fig. 1.

¿ Manual of geology, 2d ed., 1876, p. 628. 
rift in all granites to such an arrangement of the feldspars, which, however, proves to be exceptional. ${ }^{1}$

\section{FLOW STRUCTURE.}

Flow structure consists of a distribution of the mica scales in greater or less abundance in alternating bands, the general course of which was governed by that of the flow of the granite in its original molten state. Flow structure should not be confounded with any rearrangement of the mica in the complex physical and chemical processes of metamorphism. Flow structure at the Stony Creek quarries strikes N. $70^{\circ}$ W., and also N. $65^{\circ}$ E. ; at Masons Island in Stonington it strikes about north. At Millstone Point the quartz monzonite has a meandering flow structure, as shown in figure $8 c$ (p. 111), striking N. $45-60^{\circ} \mathrm{W}$. At the Anguilla quarry in Stonington a similar granite has a flow striking east-west. At Pawcatuck, near Westerly, the biotite granite shows flow structure with the same course.

\section{INCLUSIONS.}

Inclusions are important, for they are specimens of the rocks that originally overlay the granite and they indicate the age of the intrusion. At the Stony Creek quarries they consist of diorite gneiss ând mica diorite gneiss. At the Hoadly Point east quarry an inclusion of mica diorite gneiss appears to have been elongated in the direction of the flow structure. Inclusions abound at the Millstone quarry, and the two largest have diameters of 20 and 36 feet. Most of them are biotite gneiss like the capping, but some are diorite gneiss. They are generally associated with lenses of pegmatite or are inclosed by pegmatite dikes, or the granite has become banded about them. (See fig. $8, a, b, d$, p. 111.) One of these diorite gneiss inclusions is much cross veined with quartz, some of the veins starting from the surface of the granite, others from within it. The quartz monzonite of the Waterford quarry (p. 116) contains inclusions of gneiss resembling that which overlies it. The same is true at the McGaughey quarry, at Mystic. The quartz monzonite of Reynolds Bridge (p. 72) contains an inclusion of plicated quartz monzonite gneiss, evidently a part of the capping. At the Torrington Borough quarry a pegmatite dike, 20 feet thick, contains two inclusions of the adjacent biotite granite gneiss, each 10 feet in diameter.

\section{PLICATED GNEISS STRUCTURE.}

The change from the granitic to the gneissic texture has been dwelt upon by Prof. Gregory (pp. 16-18). At Hoadly Point the coarse porphyritic granite gneiss has undergone a further change in

${ }^{1}$ See Bull. U. S. Geol. Survey No. 354, 1908, pp. 19-22.

$97730^{\circ}-$ Bull. $484-11-4$ 
consequence of lateral pressure, so that the gneissic foliation has become coarsely plicated and in one place faulted, as shown in figure 4. In consequence of its acquired foliaceous texture the granite has acted under lateral pressure precisely as would an unaltered sedimentary rock or a schist of metamorphic sedimentary origin. At the Scott quarry, in Waterford (p. 106), the gneiss foliation is plicated along the strike.

\section{GRANITE DIKES.}

The fine quartz monzonites of Connecticut, like those of Rhode Island, occur as dikes, or apparent dikes, ${ }^{1}$ in various gneisses. At the Waterford quarry there are two such parallel dikes with an intervening strip of gneiss. The relations are shown in figures. 9 and 10. 'The thickness of the various dikes measured at a right angle to their inclination ranges from 12 to 40 feet, but at the Millstone quarry the relations are not clear. The granite is exposed for a depth of 50 to 125 feet and a width of 50 to 300 feet, approximately, and is capped here and there by 25 feet of gneiss, but no underlying gneiss is yet exposed, although the abundance of inclusions at the bottom of the quarry may indicate its proximity.. If the width of the granite at right angles to the flow, which appears to dip $35^{\circ} \mathrm{SW}$., be taken as 200 feet, the thickness of the granite would be about 114 feet. It is possible that a part of this quarry overlies the vertical portion of a granite dike.

At the Torrington Borough quarry a finely banded biotite granite gneiss associated with pyritiferous quartz-mica diorite gneiss is crossed by a network of dikes-the largest 6 inches thick-of bluish gray quartz monzonite, which has acquired a gneissic texture.

\section{PEGMATITE DIKES.}

Pegmatite in lenses or in small dikes occurs at nearly all the quarries described. The 20 -foot dike, with large gneiss inclusions, at the Torrington Borough quarry has been referred to, also the presence of pegmatite near or about such inclusions at the Millstone quarry (fig. $8, b, d$, p. 111). Small dikes of pegmatite recur at frequent intervals at that quarry, intersecting one another with dip $30^{\circ}$ NW. and SE. The permeation of Stony Creek granite gneiss with pegmatite differentiates it from many granites and partly accounts for its very irregular texture. (See p. 81 and Pl. III, A.) The biotite granite of the MacCurdy quarry, at Lyme, is really a pegmatite occurring as dikes, 15 to 22 feet thick, cutting a mass of finely banded granite gneiss. (See p. 102.). At the Slater quarry, in Glastonbury (p. 67), a 12-inch pegmatic dike in fine porphyritic biotite granite gneiss contains muscovite crystals, the largest 5 inches

${ }^{1}$ See Bull. U. S. Geol. Survey No. 354, 1908, p. 190. 
across and 4 inches thick. At the Center Groton quarry the quartz monzonite on either side of a 4-foot pegmatite dike has been darkened. Dikes from 6 inches to 2 feet thick abound in the Holbrook quarry at Seymour. (See p. 91 and fig. 5.) At the Benvenue quarry in Middletown small pegmatite dikes are bordered with bands of feldspar and hornblende and the granite gneiss itself also contains hornblende.

Generally pegmatite dikes contain the same minerals as the granite they penetrate, but in larger particles. In the very fine granites such dikes afford a ready means of observing in the field the chief constituents of the granite they penetrate.

The pegmatite of Lyme village contains apatite, that of the Oneco quarry fluorite and epidote, that of Pawcatuck allanite, that of the Mascetti quarry in East Litchfield and the Potter quarry in Ansonia black tourmaline, and that of several other quarries garnets, all in small particles or crystals. No time was spent searching for rare minerals.

The pegmatite of the Collins quarry in Danbury (p. 54), owing to crustal motion, has all its quartz granulated like that of the gneissoid granite of Milford, Mass., and its feldspars crossed and bordered with crushed feldspar. Crushed feldspar borders occur also in the pegmatite of the Torrington Borough quarry.

\section{APLITE DIKES.}

Dikes of aplite were observed at the Roxbury, Benvenue, Bolton, Greenwich, and Sterling quarries. Aplite is also associated with pegmatite at several other quarries.

At Roxbury some of the aplite is rose colored, and the larger dikes are 4 feet thick. Its particles are all under $0.1 \mathrm{inch}$, and consist of oligoclase andesine, smoky amethystine quartz, microcline, rare muscovite, and microscopic garnets. The feldspars have crush borders, the dikes having been exposed to the same pressure that made a gneiss of the inclosing granite. A white aplite from the same quarry has oligoclase albite as its chief feldspar.

At Benvenue the aplite is white to rose colored, and the larger dikes are a foot thick. Its particles are all under 1 millimeter, and consist of quartz, orthoclase and microcline, oligoclase, and rare biotite with accessory pyrite, titanite, allanite.

At the Peterson quarry, in Bolton, an 18-inch bluish-gray aplite of slightly gneissose texture has quartz and feldspar particles from 0.11 to 0.33 millimeter, with some porphyritic ones from 0.54 to 0.84 millimeter, and consists of smoky quartz, bluish microcline and orthoclase, white plagioclase, and rare biotite. 
The diorite gneiss of Greenwich is crossed by a network of aplite dikes, the largest 3 inches thick, of bluish-gray color, with particles under 0.76 , mostly under 0.57 millimeter, and consists of quartz with cavities in sheets, microcline and orthoclase, andesine, and probably oligoclase andesine, rare and minute biotite, with accessory pyrite, apatite, titanite; zircon.

At the quarries near Oneco, in Sterling, the larger aplite dikes are a foot thick and the aplite is cream colored, with particles ranging in diameter from 0.05 to 1.11 millimeters. It consists of clear, colorless quartz with cavities, microcline, and orthoclase, rare and minute biotite, and accessory ilmenite, garnet, and apatite. A small dike contains a central band of ilmenite.

\section{MINERAL VEINS.}

At the Roxbury quarry, owing to the proximity of a vein of siderite which was formerly mined, three veins, each not over 8 inches thick, consisting of siderite, pyrite, chalcopyrite, galena, and secondary quartz coating crystals of siderite, occur within and parallel to three vertical headings which strike northwest.

\section{CONTACTS.}

Granite is in contact with gneiss at Thomaston (p. 72) ; at Groton (p. 9); at the Millstone and Waterford quarries, in Waterford (pp. 110, 115, and figs. 9, 10); at the Anguilla quarry, in Stonington (p. 103); at the Niantic quarries (p. 98); and at Mystic (p. 96). At the Holbrook quarry, in Seymour (p. 91, fig. 5), the rock that overlies the granite gneiss is very schistose, biotitic, and in places much plicated. The most impressive features of these contacts are (1) the irregularity of the contact surface, particularly at the Millstone quarry, where its outline is rudely serrate; (2) the vast amount of erosion which has taken place to reduce an original gneiss mass of sufficient magnitude to afford adequate pressure for the formation of granite to remnants hardly 25 feet thick; (3) the evidence afforded by the superposition of a granite gneiss upon a granite that granitic intrusions recurred here, and, in those places where the lower granite is somewhat gneissose, that regional metamorphism also recurred.

\section{SHEET STRUCTURE.}

At the Waterford quarry, as shown in figure 11, the granite sheets are not continuous with those of the overlying gneiss, a discontinuity that may be attributed either to textural differences between the two rocks or to the fact that the sheet structure of the gneiss was formed prior to the intrusion of the granite and under a different kind of stress. At the Salter quarry, in Groton, the sheets of granite dip $20^{\circ}$ $\mathrm{SW}$., those of the gneiss cap dip $15^{\circ} \mathrm{S}$. 
In the more schistose granite gneisses sheet structure is in general parallel to the gneiss foliation.

At the Norcross quarry, in Stony Creek, a few inches of "shake structure," or miniature sheet structure, occur along the sheet surfaces. This structure occurs on a more extensive scale at Sachem Head quarry, where in places it appears on the whole working face.

\section{JOINT STRUCTURE.}

Ninety-nine compass observations were taken on different sets of joints in fifty quarries. Of these the most frequently recurring sets are those striking about north $\left(\mathrm{N} .10^{\circ} \mathrm{E}\right.$. to N. $10^{\circ}$ W.) ; about eastwest (N. $75^{\circ}-90^{\circ}$ E. and N. $85^{\circ}-90^{\circ}$. W.) ; about northeast (N. $40^{\circ}-$ $50^{\circ}$ E.) ; about north-northeast (N. $15^{\circ}-35^{\circ}$ E.) ; and about northnorthwest $\left(\mathrm{N} .15^{\circ}-35^{\circ} \mathrm{W}\right.$.). Then follow those striking $\mathrm{N} .4 .0^{\circ}-55^{\circ}$ W. and N. $60^{\circ}-70^{\circ}$ E., which are about equally abundant.

\section{SEGREGATIONS.}

Biotitic segregations were noticed at the Stony Creek, Wateriord, and Benvenue quarries. At the last they attain a length of 3 feet 8 inches and taper in the direction of the gneiss foliation.

\section{GEODES.}

At the Murray quarry in Pawcatuck, Stonington, a 5-inch geode lined with crystals of pyrite was found.

\section{SECONDARY QUARTZ ON JOINT FACES.}

At the Hall quarry, in Norwalk (p. 60), the parted joints of a heading are coated with secondary quartz or injected with quartz dikes to a thickness of 2 inches.

\section{VEINLETS OF ZEOLITE.}

At the McGaughey quarry, in Mystic village in Groton (p. 96), the quartz monzonite has veinlets of two zeolites. One of these minerals replaces some of the feldspar. 


\title{
PART II. ECONOMIC DISCUSSION. ${ }^{1}$
}

\author{
By T. Nelson Dale.
}

\section{DESCRIPTION OF THE QUARRIES AND THEIR PRODUCT.}

\section{METHOD.}

The quarries will be taken up by counties in alphabetical order: Fairfield, Hartford, Litchfield, Middlesex, New Haven, New London, Tolland, Windham, and the towns in each county will be taken up in like order. The particulars of each quarry will be given in the following order:

1. Name and location of quarry; name and office address of operator.

2. The granite, its technical and trade names; its color, texture, minerals, estimated mineral percentages; its chemical composition and physical qualities, as shown by any available analyses or tests.

3. The quarry, date of opening, its approximate dimensions, and thickness of stripping.

4. Rock structure, comprising sheets, joints, headings, their strike, dip, and spacings; rift and grain, flow structure, dikes, veins, "knots," discoloration, and weathering. Where the structure is complex, a diagram of the courses is given.

5. The plant, with the number of machines of each kind, and of air tools, to show its capacity.

6. Transportation, including distance to dock or railroad and method of transportation.

7. Use of explosives and method of quarrying wherever these are of special interest.

8. The product, its uses and chief market, and the names and location of a few specimen buildings and monuments.

\section{FAIRFIELD COUNTY.}

\section{BRIDGEPORT.}

BURLISON QUARRY.

The Burlison quarry (formerly known as the Parsons quarry) is in the township of Bridgeport, on the Trumbull Road, about 750 feet

\footnotetext{
${ }^{1}$ Some of the names used in this economic discussion are those by which the granites are known to the trade and are not used in a geologic formational sense. 
south of the Trumbull line and about $3 \frac{1}{2}$ miles north-northeast of the Bridgeport railroad station. (See map, Pl. I, p. 8.) Operator, Dr. Henry H. Burlison, 133 Kossuth Street, Bridgeport, Conn.

The granite (specimen D, XXX, 40,a) is a muscovite-biotite granite gneiss of medium bluish-gray color and fine-grained gneissose texture, with finely laminated, unplicated foliation, its particles being under 0.2 inch. Its constituents, in descending order of abundance, are bluish translucent potash feldspar (microcline and orthoclase); clear, colorless quartz; bluish translucent soda-lime feldspar (oligoclase-andesine) ; muscovite (white mica) ; biotite (black mica). Accessory zircon and apatite. Secondary white mica and calcite, but not enough to effervesce with muriatic-acid test.

Owing to its foliaceous texture the stone looks very different on its rift, grain, and hardway sides, and the muscovite gives its rift face a brilliant sheen.

The quarry measures about 100 by 50 feet and is 25 to 30 feet deep. The stripping consists of 3 feet of sand and bowlders.

Rock structure: The gneiss foliation strikes N. $30^{\circ}$ E. and is vertical. The sheets, from 6 inches to 3 feet thick, dip $25^{\circ}$ NE., and are in places horizontal. There are three sets of joints: Set $A$, striking N. $50^{\circ} \mathrm{W}$., dips $40^{\circ}$ to $50^{\circ} \mathrm{NE}$. and is spaced 3 to 40 feet; set $\mathrm{B}$, striking $\mathrm{N}$. $55^{\circ} \mathrm{W}$., dips $60^{\circ} \mathrm{SW}$., forms a heading at the northnortheast wall, one 50 feet south of it, and a third at the south-southwest wall; set C, striking about north, dips steep east and forms a heading on west side. The rift seems to correspond to the foliation (N. $30^{\circ}$ E., vertical) and the grain to be horizontal and the hardway vertical, N. $50^{\circ} \mathrm{W}$. Pegmatite occurs parallel to the foliation.

The plant comprises a derrick, small hoisting engine, and steam pump.

Transportation is by cartage to Bridgeport.

The product is used for cellars, walls, and sills, for which its even foliation well adapts it. Specimen: The trimmings of the Bridgeport railroad station.

JAIL QUARRY.

The Jail quarry is in the city of Bridgeport, on Madison Avenue, on the county jail property, about $1 \frac{1}{4}$ miles northwest of the railroad station. (See map, Pl. I.) Operator, Bridgeport Stone Co., Bridgeport, Conm

The granite (specimen $\mathrm{D}, \mathrm{XXX}, 41, a$ ) is a biotite granite gneiss of dark bluish-gray color and fine gneissose, in places banded texture, with particles under $0.1 \mathrm{inch}$. In a thin section they measure up to 0.72 millimeter, but mostly under 0.56 millimeter. It is less micaceous and less foliaceous than the Burlison quarry stone. Its constituents, in descending order of abundance, are bluish potash feldspar 
(microcline and orthoclase); clear, colorless quartz with cavities in sheets; bluish translucent to milk-white soda-lime feldspar (oligoclase), somewhat kaolinized and intergrown with quartz, somewhat circular in cross section; biotite (black mica) and a little muscovite or bleached biotite. Accessory apatite. Secondary kaolin. No effervescence with muriatic-acid test.

The quarry is on the southwest side of a northwest-southeast ledge 400 feet in length and 15 to 20 feet high, which is the working face.

Rock structure: The gneiss foliation strikes N. $40^{\circ}$ E. and dips $45^{\circ} \mathrm{NW}$. The mass is broken up by many intersecting headings into fragments from 4 to 12 inches and exceptionally 3 feet square.

The plant comprises a steam drill and a stone crusher.

The product consists of crushed stone for cement cellar work, also for artificial building stone and curbing, which are made on the premises. Where the headings admit the gneiss is split up for wall stone. The quarry is practically worked by the county, as the prisoners in the jail are the workmen, but the product reaches the market through the Bridgeport Stone Co.

DANBURY.

COLLINS QUARRY.

The Collins quarry is in Danbury township, at the north foot of Town Hill, $1 \frac{1}{4}$ miles south-southeast of Danbury railroad station. (See map, Pl. I.) Operator Daniel W. McNamara, 100 South Street, Danbury.

The granite (specimens $\mathrm{D}, \mathrm{XXX}, 56, a, b)$ is a biotite granite gneiss of medium inclining to dark bluish-gray color and very fine gneissose texture, with fine whitish and dark gray and black bands. The thin section shows particles up to 0.84 and 1.12 millimeters or about 0.04 inch. Its constituents, in descending order of abundance, are clear bluish potash feldspar (microcline); light, smoky quartz showing effects of strain; translucent whitish soda-lime feldspar (oligoclase); and biotite (black mica). Accessory pyrite and zircon. Secondary calcite. Some of the feldspars have crush borders. The rock effervesces with cold dilute muriatic acid.

The quarry measures about 150 by 75 feet with a working face on the south 15 to 40 feet high.

Rock structure: The gneiss foliation strikes N. $25^{\circ}$ to $35^{\circ} \mathrm{W}$. and dips $80^{\circ} \mathrm{NNE}$. to $90^{\circ}$. There is no proper sheet structure, but there are discontinuous fractures,-from 6 inches to 3 feet apart, dipping $10^{\circ}$ W. Pegmatite dikes up to a foot thick run parallel to the foliation. This coarse pegmatite consists largely of light-gray to cream-colored potash and soda-lime feldspar (oligoclase), more or less kaolinized and micasized. The oligoclase is obscurely intergrown, probably 
with albite. The feldspars are crossed and bordered by veinlets of crushed feldspar. Then comes quartz, which is clear, colorless, granulated, and contains hairlike crystals of rutile and cavities in parallel sheets; lastly very little biotite and still less bleached biotite.

The plant comprises a derrick, small hoisting engine, and a small stone crusher with meshes of $2,1 \frac{1}{2}$, and one-half inches.

Transportation is by cartage.

The product consists of crushed stone for streets and roads. The pegmatite is mixed with the gneiss. The operator claims that an 1.8-year's' test of this crushed gneiss and pegmatite shows fair results, even when compared with a like test of crushed trap on the same road.

TREADWELL PROSPECT.

The Treadwell prospect is in Danbury township, $1 \frac{3}{4}$ miles northnorthwest of the Danbury railroad station, on a ridge east of the Padanaram road, on the farm of Stephen B. Treadwell. (See map, Pl. I, p. 8.)

The granite is an unevenly banded, fine-grained, dark to medium pinkish gray biotite gneiss. It consists of pinkish and milk-white feldspar, sinoky quartz, and black mica.

Stone has been quarried for underpinning, off and on for 10 to 15 years, from small openings 250 and 500 feet east of the house.

Rock structure: The gneiss foliation strikes $\mathrm{N}$. $45^{\circ}-55^{\circ} \mathrm{W}$. and dips $50^{\circ} \mathrm{NE}$. to $90^{\circ}$. It is

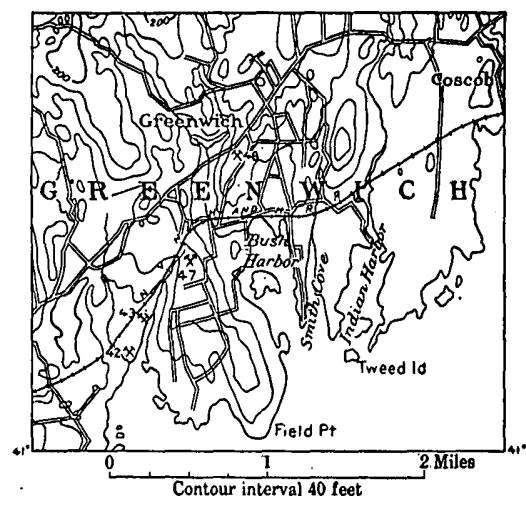

Figure 1.-Map of part of Greenwich, Conn., showing locations of granite (diorite gneiss) quarries. 42; Ritch ; 43 , Voorhis; 47, Christiano, Oak Ridge ; 48, Christiano, Fiamilton Avenue. injected with pegmatite. The ledges are probably extensive, but aro concealed by a thin cover of gravel and clay.

\section{GREEN WICH. \\ VOORFIS QUARRY.}

The Voorhis quarry is in Greenwich Township at the head of Byram Harbor, a mile southwest of the Greenwich railroad station. (See maps, Pl. I and fig. 1.) Operator, Jacob Voorhis, Greenwich, Conn.

The Greenwich blue-black granite (specimen $\mathrm{D}, \mathrm{XXX} 43, a$ ) is a mica diorite gneiss of extremely dark bluish-gray color (darker than "Quincy extra dark") and of coarse porphyritic gneissose texture, 
with feldspars, mostly twins, forming lenses up to 2 by 0.4 inches, but mostly not over 1 by $0.3 \mathrm{inch}$, and down to 0.3 by 0.1 inch. The long axes of these lenses are parallel to the rock foliation and the plane between the twin crystals is nearly so. The constituents of the rock, named in descending order of abundance, are medium bluish translucent gray soda-lime feldspar (andesine, with possibly oligoclase-andesine), some in large twins, a little micasized and koalinized; biotite (black mica); clear, colorless potash feldspar. (microcline); clear, colorless quartz; and green hornblende. Accessory minerals: Pyrite, titanite, apatite, allanite, and zircon; the three first in some abundance. Secondary minerals: Epidote, kaolin, a white mica, calcite. The rock effervesces slightly with cold dilute muriatic acid.

Two tests of the ultimate transverse strength of this granite made at the United States Arsenal at Watertown in November, 1896, on pieces 15 inches long between supports, yielded these results:

Results of transverse tests of Greenwich, blue-black granite and Quincy granite.

\begin{tabular}{|c|c|c|c|c|c|}
\hline . & Test No. & Breadth. & Depth. & $\begin{array}{l}\text { Breaking } \\
\text { weight. }\end{array}$ & $\begin{array}{l}\text { Modulus of } \\
\text { rupture. }\end{array}$ \\
\hline 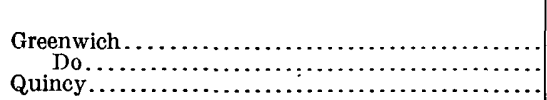 & $\begin{array}{l}9762 \\
9763 \\
9765\end{array}$ & $\begin{array}{r}\text { Inches. } \\
1.01 \\
1.02 \\
1.01\end{array}$ & $\begin{array}{r}\text { Inches. } \\
1.02 \\
1.02 \\
1.02\end{array}$ & $\begin{array}{r}\text { Pounds. } \\
152 \\
177 \\
177\end{array}$ & $\begin{array}{r}\text { Pounds. } \\
a 3,257 \\
a 3,757 \\
2,164\end{array}$ \\
\hline
\end{tabular}

${ }^{a}$ Average modulus of rupture of Greenwich granite, 3,507 pounds.

The rock is exceedingly tough under the hammer. It is dark yet brilliant, and the contrasts between its black mica and bluish-gray feldspars are very marked and pleasing. Its apparent texture and shade differ on its three sides. The side parallel to the foliation, showing hardly any feldspar, is black; the side at right angles to the foliation and parallel to the long axes of the lenses shows the feldspar most conspicuously; and the side transverse to those axes shows the light and dark minerals more evenly mixed. Were the stone to be set on the edge of its foliation the structure would be almost black. Its appearance would differ somewhat according as the grain face or the hardway face were alone exposed, and if the stones were laid promiscuously, without regard to texture, the effect would be still different.

The quarry, opened before 1833, measures about 500 feet from north to south by 200 feet from east to west, and 50 feet in depth.

Rock structure: The gneiss foliation strikes N. $15^{\circ}-20^{\circ} \mathrm{E}$. and is vertical. The sheets, from 1 to 35 feet thick, strike N. $80^{\circ}$ W., dip $20^{\circ} \mathrm{S}$. and are mostly separated by small aplite dikes. One set of joints only; strike N. $65^{\circ} \mathrm{W}$., dip vertical or very steep and slickensided. The rift is reported as parallel to the foliation, the grain as 
vertical with $\mathrm{N} .80^{\circ} \mathrm{W}$. course and the hardway horizontal. Small dikes of aplite (described under heading "Ritch quarry") run parallel to the foliation and also undulate horizontally.

The plant consists of three horse derricks.

Transportation is by cartage of 500 feet to a wharf, which admits schooners of $6 \frac{1}{2}$ feet draft at high tide.

The product is used for buildings and massive structures and the waste for riprap. Specimens: Fort Schuyler, on Throgs Neck, Long Island Sound; physicians' quarters at south end of Blackwells Island, East River; Episcopal Church, Port Washington, Long Island; residence of C. J. Osborn, Mamaroneck, N. Y.; wall about Trinity Cemetery, One hundred and fifty-third Street and Broadway, New York City.

RITCH QUARRY.

The Ritch quarry is in Greenwich Township on the west side of Byram Harbor, 1 $1 \frac{1}{4}$ miles southwest of Greenwich railroad station. (See map, fig. 1, p. 55.) Operators, W. and S. Ritch, Port Chester, N. Y.

The granite (specimens D, XXX, 42, $a, b$ ), Greenwich blueblack granite, is a mica diorite gneiss of extremely dark bluish-gray color and coarse porphyritic gneissose texture identical with that of the Voorhis quarry, fully described on page 55 .

The quarry is about 200 feet square, with working faces 15-40 feet high on the north, south, and west.

Rock structure: The gneiss foliation strikes N. $20^{\circ}$ E. and dips $90^{\circ}$. The sheets, from 2 to 3 feet thick and generally separated by thin aplite dikes, dip $25^{\circ} \mathrm{W}$. There are two sets of joints: A, striking N. $80^{\circ} \mathrm{W}$., vertical, forms the north and south walls, and two headings near the center, and is spaced 2 to 10 feet; $B$, striking $\mathrm{N} .15^{\circ}-20^{\circ} \mathrm{W}$., vertical, is spaced 10 feet or more. The rift is reported as parallel to the foliation, the grain vertical with N. $80^{\circ}$ W. course, and the hardway horizontal. Pegmatite dikes, mostly of feldspar, the largest 16 inches thick, meander vertically along the foliation. Dikes of aplite from one-fourth inch to 2 inches thick (specimen D, XXX, 42,c), are of medium bluishgray color and very fine texture with particles under 0.1 inch. A thin section shows them under 0.76 millimeter and mostly under 0.57 millimeter. The constituents of the rock, named in apparent descending order of abundance, are quartz with cavities in sheets; potash feldspar (microcline and orthoclase); soda-lime feldspar (andesine and probably oligoclase-andesine), a little of it micasized; and very sparse minute biotite. Accessory minerals: Pyrite, apatite, titanite, zircon. Secondary minerals: A white mica, calcite. This aplite thus differs from the gneiss only in its poverty of mica and richness of quartz. Rusty stain affects sheet and joint faces to an inch in thickness. 
The plant consists of a horse and a hand derrick.

Transportation requires cartage of 500 feet to wharf, which admits schooners of 7 feet draft at high tide.

The product is used for buildings and street work and the waste for riprap. Specimens: Catholic churches in Flushing, Long Island, Mamaroneck, N. Y., and Stamford, Conn.; Catholic cathedral and bishöp house at intersection of Vanderbilt, Lafayette, Clermont and Green avenues, Brooklyn.

\section{CHRISTIANO OAK RIDGE QUARRY.}

The Christiano Oak Ridge quarry is in Greenwich Township at the north end of the ridge between Bush and Byram Harbors, about three-fifths mile west-southwest of the Greenwich railroad station. (See fig. 1.) Operator, Joseph Christiano, Greenwich, Conn.

The granite (specimen D, XXX, 47, a), Greenwich blue-black granite, is an extremely dark bluish gray mica diorite gneiss, identical with that of the Voorhis quarry, described on page 55, excepting that it has a little augite besides the hornblende.

The quarry, opened in 1901, measures about 175 by 150 feet and is from 10 to 20 feet deep.

Rock structure: The gneiss foliation strikes N. $15^{\circ}-20^{\circ}$ E. and dips $90^{\circ}$. The sheets, from 2 to 10 feet thick, are horizontal or dip very low east. There are four sets of joints: Set A, striking $\mathrm{N}$. $75^{\circ}$ W., vertical, is spaced 1-10 feet; set B, striking N. $20^{\circ}$ E., vertical or steep west, spaced 3-10 feet, coinciding with the small aplite dikes; set $\mathrm{C}$, striking N. $30^{\circ}$ W., vertical (exceptional), spaced as low as 5 feet; set $\mathrm{D}$ (one only), striking N. $85^{\circ} \mathrm{W}$., dipping $55^{\circ}$ about north. Pegmatite dikes, in bead-like lenses up to 8 inches thick, are either parallel to the foliation or branch from it. The numerous aplitic dikes, from 0.25 to 3 inches thick, strike with the foliation, but have plications from 1 to 6 feet across. This aplite (specimen $\mathrm{D}, \mathrm{XXX}, 47, b$ ) is of very light gray shade and very fine texture, with feldspars under 0.1 inch. Its constituents, in descending order of abundance, are quartz, andesine, and probably oligoclase-andesine, some of it micasized; microcline, with orthoclase, possibly as abundant as the other feldspar; sparse biotite, with secondary white mica and calcite.

The plant consists of a portable boiler, a steam drill, hand derrick, and portable stone crusher, with screens of 2,1 , and one-half inches.

Transportation is by cartage.

The product is used for buildings and the waste is crushed for roads. Specimen buildings: Catholic Church, Bruce Memorial gate (Bruce Park, Greenwich Avenue and Steamboat Road), and residence of Charles Hirshhorn, North Street, Greenwich. 
CHRISTIANo HAMILTON AVENUE QUARRY.

The Christiano Hamilton Avenue quarry is in Greenwich Township, half a mile northwest of the Greenwich railroad station. (See fig. 1, p. 55.) Operator, Joseph Christiano, Greenwich, Conn.

The granite (specimen D, XXX, 48, a), Greenwich blue-black granite, is a mica diorite gneiss of extremely dark bluish gray color and identical with that of the Voorhis quarry, described on page 55.

The quarry, opened in 1873, measures about 60 by 30 feet and is from 10 to 20 feet deep.

Rock structure: The gneiss foliation strikes N. $15^{\circ} \mathrm{E}$. and is about vertical. Sheets are hardly developed. There are two sets of joints: Set A, striking N. $45^{\circ}$ W., vertical, is spaced 8 to 15 feet; set $\mathrm{B}$, loose, striking N. $15^{\circ} \mathrm{E}$., vertical, is spaced 10 feet. The rift is reported as parallel to the foliation, the grain at right angles to it and vertical, and the hard way horizontal.

Transportation is by cartage.

The product is used for buildings. Specimens: Residences of George E. Weed, Rockside Park, and of James McCutcheon, Belle Haven Park, Greenwich.

\section{NORWALK.}

HALL QUARRY.

The Hall quarry. (formerly known as the Bates quarry) is in Norwalk Township, about $1 \frac{1}{2}$ miles northeast of the Norwalk railroad station. Operator, Irving Hall, 106 Main Street, Norwalk, Conn.

The granite (specimen $\mathrm{D}, \mathrm{XXX}, 44, a$ ) is a muscovite-biotite granite gneiss of light warm gray shade and of gneissose medium inclining to fine texture, with feldspars and mica to $0.25 \mathrm{inch}$. It: is brightly spangled with mica on its foliation face. Its constituents, named in descending order of abundance; are light cream colored potash feldspar (microcline), but little kaolinized; pale, smoky quartz, with cavities in sheets; milk-white soda-lime feldspar (oligoclase albite) much kaolinized, micasized, and with calcite; muscovite (white mica); and biotite (black mica). Accessory minerals: Garnet, apatite. Secondary minerals: Kaolin, a white mica, calcite, some in veinlets. The rock effervesces freely in places with cold dilute muriatic acid.

The quarry is about 50 feet square and from 20 to 30 feet deep.

Rock structure: The gneiss foliation dips $5^{\circ}$ to $20^{\circ} \mathrm{NW}$. The sheets, 1 to 4 feet thick, parallel to the foliation, are but imperfectly developed. There are two sets of joints: Set A, striking $\mathrm{N} 40^{\circ} \mathrm{E}$., vertical, forms the north wall; set $\mathrm{B}$, striking northwest, vertical, forms the east and west walls and an 8-foot-wide heading near 
the north wall and is spaced 2 to 8 feet. Some of the joints of this heading have been parted 0.25 to 2 inches and filled with quartz. Both sets of joints are slickensided. The rift is along the foliation.

Transportation is by cartage.

The product is used for walls, underpinning, steps, etc. The quarry is worked only occasionally.

\section{HARTFORD COUNTY.}

\section{GENERAL CONDITIONS.}

There are two quarries in Bristol which, when fully opened, may yield serviceable structural granite.

The rock is a garnetiferous quartz monzonite gneiss of finebanded texture.

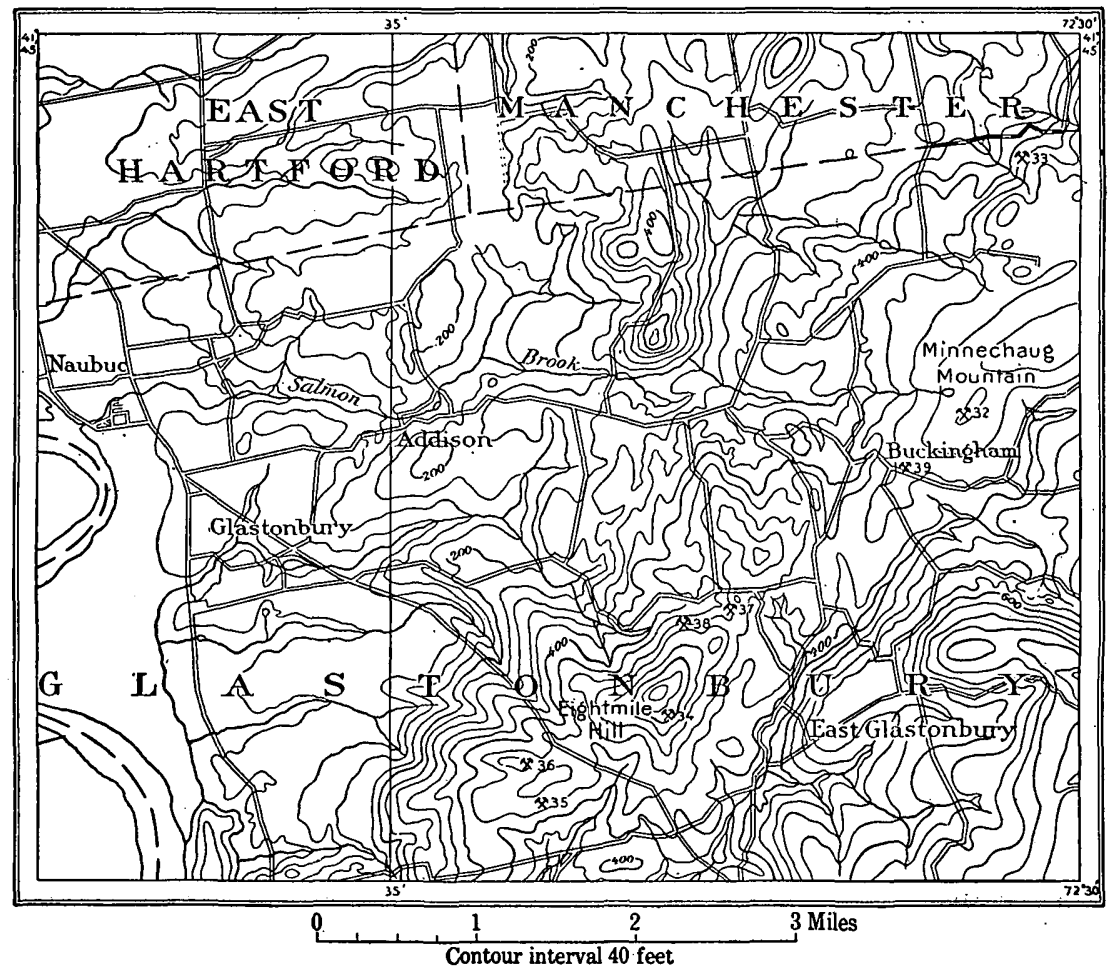

Figure 2.-Map of Glastonbury granite gneiss quarries. 32, Corbin; 33, Gorman ; 34, Danielson; 35 , Belden quarry; 36, Curtis ; 37, Brooks : 38, Slater ; 39, Carline.

The other quarries are in the township of Glastonbury. As will be seen on the map ('fig. 2), these are scattered along a S. $48^{\circ} \mathrm{W}$. to N. $48^{\circ}$ E. ridge, the north part of which is now known as Minnechaug Mountain, called also locally Birch Mountain, and the south part of which goes by the name of Eightmile Hill. The gneiss foliation at the quarries strikes $\mathrm{N} .45^{\circ}-80^{\circ}$ E., averaging about $\mathrm{N}$. $60^{\circ} \mathrm{E}$., and thus differs but little from the trend of the ridge. The strike at Curtis quarry, however, is about north. 
The Peterson quarry in Bolton, in Tolland county (p. 116), is on the northeast continuation of the same ridge. The strike there is N. $10^{\circ} \mathrm{E}$.

The rock at these quarries is a more or less obscurely porphyritic biotite granite gneiss, with feeble mineral contrasts and a marked foliation, but its texture and shade vary slightly at different quarries. It is designated on the State preliminary geologic map as the "Glastonbury granite gneiss," No. 15. The Glastonbury quarries have long supplied curbing and crosswalks to the city of Hartford, for which the foliation of the stone admirably adapts it.

BRISTOL.

DUNN QUARRY.

The Dunn quarry is on Divinity Street, in Bristol, about a mile west-southwest of the center of the borough. (See Pl. I.) Operator, Edward Dunn, Northside Hotel, Bristol, Conn.

The granite (specimen D, XXX, 62, a, "Bristol granite gneiss," No. 10, of the State preliminary geologic map) is a garnetiferous quartz monzonite gneiss of light inclining to medium bluish gray color, and of gneissose banded fine texture with feldspars up to 0.2 inch, mica to 0.1 inch, and garnets to 0.08 inch. It has wavy bands and lenses of light and dark and reddish color, the light bands up to 0.5 inch width, the dark to 0.3 . inch, and the reddish to 0.1 inch. Its constituents, in descending order of abundance, are clear to whitish soda-lime feldspar (albite), some of it slightly kaolinized; clear bluish quartz, with cavities in sheets; a little potash feldspar (orthoclase); biotite (black mica), some of it chloritized. Accessory minerals: Garnets (fourth or fifth in order of abundance), magnetite, apatite. Secondary minerals: Kaolin, chlorite, limonite.

This is a hard, serviceable, and attractive stone.

The quarry consists of two openings, one measuring about 100 by 50 feet, and 5 to 10 feet deep, the other 50 feet square, from which, however, only the soil and weathered rock have been removed.

The gneiss foliation strikes east-west and dips steeply south. The sheets, 3 to 8 feet thick, are irregular. There are three sets of jointsA, striking about north-south, with headings 12 feet wide; B, striking about east-west; $\mathrm{C}$, diagonal. The spacing of joints in the smaller opening admits the quarrying of blocks 10 feet square by 3 to 5 feet, which is the thickness of the sheets there. The rift in both openings is across the foliation.

The plant consists of a derrick, small hoisting engine; and large steam drill.

Transportation is by cart, a mile to railroad. 
The product is used for foundations and buildings. "Brightwood," Mrs. W. A. McKay's castle mansion on West Street, in Bristol, was built of this granite, but some of it came from another now disused quarry, and some from the site of the mansion itself.

SEYMOUR STREET QUARRY.

The Seymour Street quarry, in Bristol, is operated occasionally by the Pierson Engineering \& Construction Co., Bristol, Conn.

The granite is like that of the Dunn quarry; the opening is small and irregular, and the plant consists of a hand derrick.

\section{GIAS'IONBURY.}

CORBIN QUARRY.

The Corbin quarry is in Glastonbury, at the top of Birch Mountain, 5 miles east-northeast of Glastonbury village. (See fig. 2, p. 60.) Operator, John Arthur Corbin, North Manchester, Conn.

The granite (specimen $\mathrm{D}, \mathrm{XXX}, 32, a$ ) is a biotite granite gneiss of medium gray shade and of fine gneissose texture, with porphyritic feldspars up to 0.3 inch and matrix with particles under 0.05 inch. In places it has minute brownish stains. Its constituents, in descending order of abundance, are cream-colored to milk-white potash feldspar (microcline and orthoclase), somewhat kaolinized; clear, colorless quartz; clear to translucent, colorless soda-lime feldspar (oligoclase); and biotite (black mica), some of it chloritized with a little muscovite or bleached biotite. Both feldspars are intergrown with quartz more or less circular in cross section. Accessory minerals: Epidote, ${ }^{1}$ apatite, allanite, titanite. Secondary minerals: Kaolin, limonite proceeding from allanite and producing the brown spots referred to, chlorite. No effervescence with muriatic-acid test.

The quarry is a small, irregular opening up to 10 feet deep, begun in 1905 .

Rock structure: Gneiss foliation and rift dip about $10^{\circ}$ north $50^{\circ}$ west. The sheets, up to 3 feet thick, are horizontal or dip low $\mathrm{N}$. $50^{\circ} \mathrm{W}$. Pegmatite dikes measure up to 4 inches in thickness.

The plant consists of one hand derrick.

Transportation is by cartage of 12 miles to Hartford.

The product is used entirely for curbing and circulars.

CARLINE QUARRY.

The Carline quarry is in Glastonbury Township, in the village of Buckingham, $4 \frac{1}{2}$ miles east of Glastonbury village. (See fig. 2.)

\footnotetext{
1 Rice and Gregory regarded the epidote as probably of primary origin. See their Manual of the Geology of Connecticut, 1906. Bull. Conn. State Geol. and Nat. Hist. Survey No. 6, p. 118. Some of it forms rims about allanite.
} 
Operator, Harry Carline (Enrico Carlini, anglicized), R. F. D., Glastonbury, Conn.

The granite (specimen $\mathrm{D}, \mathrm{XXX}, 39, a$ ) is a biotite granite gneiss of medium inclining to dark gray shade (thus darker than the Corbin quarry stone) and of fine gneissose texture, with porphyritic feldspars, the largest 0.3 inch, and matrix with particles under 0.1 inch. Its constituents, named in descending order of abundance, are cream-colored potash feldspar (microcline somewhat kaolinized and orthoclase); medium smoky quartz; whitish soda-lime feldspar (oligoclase to oligoclase-andesine) slightly micasized, some of it intergrown with quartz more or less circular in cross section; biotite (black mica), some of it chloritized, and a little muscovite or bleached biotite. Accessory minerals: Epidote, titanite, allanite, apatite, zircon. Secondary minerals: Kaolin, chlorite, a white mica, limonite stain, hematite. No effervescence with muriatic-acid test.

The quarry, opened in 1908, is about 40 feet square by 20 feet deep, and the surface consists of 5 feet of sand and bowlders.

Rock structure: Gneiss foliation and rift strike N. $80^{\circ}$ E. and dip $25^{\circ} \mathrm{N}$. The sheets, 10 feet thick, dip with the foliation. The grain and hardway are equal. No joints. A minute vein of quartz and biotite runs diagonal to the foliation.

The plant consists of a hand derrick.

Transportation is by cartage of 10 miles to Hartford.

The product is used for curbing, crosswalks, and steps.

GORMAN QUARRY.

The Gorman quarry is in Glastonbury, at the foot of Birch Mountain, a little south of the Manchester line, about $5 \frac{3}{4}$ miles eastnortheast of Glastonbury village. (See fig. 2, location approximate.) Operator, Patrick Gorman, 166 Main Street, South Manchester, Conn.

The granite (specimen $\mathrm{D}, \mathrm{XXX}, 33, a$ ) is a biotite granite gneiss of medium very slightly bluish gray shade, and of fine gneissose texture, with porphyritic feldspars to 0.3 inch in a matrix with particles under 0.1 inch, in a thin section mostly from 0.11 to 0.39 millimeter. Its constituents, in descending order of abundance, are milk-white potash feldspar (microcline, kaolinized, and orthoclase); pale smoky quartz showing effects of strain and with some cavities; translucent whitish soda-lime feldspar (oligoclase); biotite (black mica) and a little muscovite or bleached biotite. Accessory minerals: Epidote, magnetite, apatite, garnet, allanite. Secondary minerals: Kaolin and limonite stain. Both feldspars are intergrown. with quartz circular in cross section. No effervescence with muriaticacid test.

$97730^{\circ}-$ Bull. $484-11-5$ 
This stone.is less weathered 'han that of the last two quarries and is therefore harder. It has been used for buildings as well as steps, etc.

The quarry, not in operation in 1908 , was not visited.

DANIELSON QUARRY.

The Danielson quarry is in Glastonbury Township, on the south side of the top of Eightmile Hill, $3 \frac{1}{2}$ miles southeast of Glastonbury village. (See fig. 2.) Operator, A. Danielson \& Co., 98 Babcock Street, Hartford, Conn.

The granite (specimen $\mathrm{D}, \mathrm{XXX}, 34, a$ ) is a biotite granite gneiss of dark inclining to medium brownish-gray color and of fine marked gneissose texture with porphyritic feldspars to $0.3 \mathrm{inch}$ in a matrix with particles under 0.1 inch, in thin section mostly between 0.11 and 0.84 millimeter. Its constituents, in descending order of abundance, are pale buff to pinkish potash feldspar (microcline and orthoclase) somewhat kaolinized; medium smoky quartz showing effects of strain and with some cavities in sheets; grayish translucent sodalime feldspar (oligoclase) slightly kaolinized; and biotite (black mica). Accessory minerals: Epidote (fifth in order of abundance), apatite, magnetite, allanite. Secondary minerals: Kaolin, limonite, and hematite (stain). No effervescence with muriatic-acid test.

The quarry, opened in 1908, measures about 60 by 35 feet, and is 3 to 10 feet deep:

Rock structure: Gneiss foliation and rift strike N. $55^{\circ}$ E. and $\operatorname{dip} 25^{\circ} \mathrm{N}$. The sheets, 1 to 2 feet thick, are also parallel to these. There is one joint on north side striking N. $70^{\circ} \mathrm{E}$. and dipping $55^{\circ}$ S. $20^{\circ}$ E. Some veinlets of quartz and biotite (up to 0.1 inch thick) crossing the foliation do not weaken the stone. Vertical pegmatite dikes, 3 to 6 inches thick, strike N. $80^{\circ}$ W. Some of smoky quartz up to 4 inches thick.

The plant comprises a hand derrick.

Transportation is by cartage of 10 miles to Hartford.

The product is used for curbing and steps.

BELDEN QUARRY.

The Belden quarry is in Glastonbury Township, on Eightmile Hill, three-tenths mile south of the Hartford turnpike and 3 miles southeast of Glastonbury village. (See fig. 2.) Operator, H. T. Lingner, East Glastonbury, Conn.

The granite (specimen D, XXX, 35, a) is a biotite granite gneiss of medium buff-gray color (a trifle lighter than Concord granite) and of fine gneissose texture, with feldspars to 0.2 inch and mica, in aggregates, up to 0.5 inch, conspicuous along the foliation. Por- 
phyritic texture not apparent. Its constituents, in descending order of abundance, are cream-colored potash feldspar (microcline and or- . thoclase) somewhat kaolinized; pale smoky quartz, some of it in long laminæ 0.28 millimeter wide; whitish soda-lime feldspar (oligoclase) somewhat kaolinized; biotite (black mica) and a little muscovite or bleached biotite. Accessory minerals: Garnet (fifth in order of abundance), epidote, magnetite, allanite. Secondary minerals: Kaolin, limonite stain, calcite. No effervescence with muriaticacid test.

The quarry consists of several openings, some of which were made in 1863. The one now worked, made in 1905 , measures 50 by 40 feet, and is 20 feet deep. The stripping consists of 3 to 9 feet of clay, angular blocks, and pebbles.

Rock structures: Gneiss foliation and rift strike northeast and dip $10^{\circ}$ to $20^{\circ} \mathrm{NW}$ : The sheets, 6 inches to 5 feet thick, are parallel to these. There are two sets of joints: Set A, striking N. $20^{\circ}$ E., vertical, forms the north wall; set $\mathrm{B}$, striking $\mathrm{N}$. $65^{\circ} \mathrm{W}$., vertical, forms the east and west walls and recurs in center, discontinuous. The grain is reported as vertical with north-south course. Pegmatite dikes are up to 6 inches thick. Some smoky quartz veins or lenses.

The plant comprises a horse derrick.

Transportation is by cartage of 10 miles to Hartford.

The product is chiefly used for curbing and crosswalks, and smaller blocks for paving. Blocks $1 \frac{1}{2}$ to 2 inches thick are prepared for lining tubes at feldspar crushing works instead of the oak timber formerly used for that purpose.

CURTIS QUARRY.

The Curtis quarry is in Glastonbury Township, on Eightmile Hill. one-fourth mile southwest of the Hartford Turnpike and $2 \frac{3}{4}$ miles southeast of Glastonbury village. (See fig. 2, p. 60.) Operator, Frank Curtis, R. F. D., Glastonbury, Conn.

The granite is a biotite granite gneiss identical with that of the Belden quarry, described on page 64 .

The quarry, opened before 1901, measures about 200 feet from north to south by 40 feet across and has a working face 20 to 40 feet high on the west.

Rock structure: Gneiss foliation and rift dip $10^{\circ}-15^{\circ} \mathrm{W}$., as do the sheets, which are 1 to 8 feet thick. There are two sets of joints: Set A (one only), striking N. $20^{\circ}$ E., dipping $40^{\circ}$ S. $70^{\circ}$ E.; set B, striking north, dipping $50^{\circ} \mathrm{W}$., is spaced 10 to 20 feet or more. Pegmatite dikes, 2 to 8 inches thick, striking N. $60^{\circ}$ E., dipping $35^{\circ}$ S. $30^{\circ}$ E., recur at intervals of 10,15 , and 40 feet. A 4 -inch one strikes nearly east-west. Quartz veins 0.25 to 1 inch thick have irregular courses. 
The plant consists of two hand derricks.

Transportation is by cartage of $9 \frac{1}{2}$ miles to Hartford.

The product is used for curbing and like stonework. The quarry was worked in 1907 but not in 1908 .

BROOKS QUARRY.

The Brooks quarry is in Glastonbury Township, on the northeast side of Eightmile Hill, $3 \frac{1}{2}$ miles east-southeast of Glastonbury village. (See fig. 2.) Operator, Henry R. Brooks, R. F. D., Glastonbury, Conn.

The granite is a biotite granite gneiss of medium gray shade and fine gneissose porphyritic texture, identical in composition with that of the Corbin quarry, described on page 62 , and with the same minute brown spots, due to allanite.

The quarry, opened in 1889 , measures about 400 feet from east to west by 150 feet across at one end and 50 at the other, and is from 5 to 60 feet deep.

Rock structure: The gneiss foliation and rift strike N. $70^{\circ}$ E. and $\operatorname{dip} 25^{\circ} \mathrm{N} .20^{\circ} \mathrm{W}$. The sheets, from 1 to 6 feet thick, are parallel to these. There are two sets of joints: Set A, striking N. $75^{\circ} \mathrm{E}$., dipping steep S. $15^{\circ}$ E., is spaced 10 to 20 feet; set B, striking N. $35^{\circ}$ W., vertical, is spaced 20 feet. The grain is vertical, north to south, but the stone breaks with equal facility along the hardway. Four vertical pegmatite dikes, the largest 10 inches thick, strike N. $77^{\circ}$ $\mathrm{W}$., and are 10 feet or more apart. This pegmatite (specimen $\mathrm{D}$, XXX, 37, b) consists of cream-colored feldspar and smoky quartz, with sparse minute garnets and rare scales of biotite and muscovite.

The plant consists of five hand derricks.

Transportation is by cartage of 10 miles to Hartford or of $\breve{\partial} \frac{1}{2}$ miles to rail at South Manchester, or of 5 miles to wharf at Naubuc (Glastonbury landing), on the Connecticut.

The product is used for curbing and building.

Specimens: Curbing and steps, Cheney Park, South Manchester, and trimmings on Methodist Church at Windsor, Conn.

SLATER QUARRY.

The Slater quarry is in Glastonbury township, one-fourth mile west-southwest of the Brooks quarry and about $3 \frac{3}{4}$ miles southeast of Glastonbury village. (See fig. 2.) Operator, Nelson Slater, R. F. D., Glastonbury, Conn.

The granite is a biotite granite gneiss, identical with that of the Corbin quarry described on page 62 .

The quarry, opened in 1905 , is 20 feet square and 15 feet deep. The stripping consists of 3 feet of sand and bowlders. 
Rock scructure: Gneiss foliation and rift strike N. $55^{\circ}$ E. and dip $30^{\circ} \mathrm{N}$. $35^{\circ} \mathrm{W}$. The sheets, from 2 to 4 feet thick, are parallel to these. There are two sets of joints: Set A, striking northeast, dipping $40^{\circ}$ SE., is spaced 15 feet; set $\mathrm{B}$, striking northwest, vertical, one only. The grain is vertical north to south, but the rock breaks equally well along the hardway. Four-inch pegmatite dikes strike N. $70^{\circ} \mathrm{W}$., and dip steep S. $20^{\circ} \mathrm{W}$. A 12 -inch vertical dike strikes N. $10^{\circ}$ E., carries muscovite in plates (the largest 5 inches square and 4 inches thick) about 6 inches apart, the rest of the dike being mostly feldspar. There are 2 to 3 inches of rusty stain on the upper sheets.

Transportation is by cartage of $9 \frac{1}{2}$ miles to Hartford. The product is used for curbing, crosswalks, and steps.

\section{LITCHFIELD COUNTY.}

CORN WALL.

BENEDICT QUARRY.

The Benedict quarry is in Cornwall Township, on the north side of White Rock, three-fourths mile east of Cornwall village. (See Pl. I, p. 8:) Owner, Trusten H. Benedict, Cornwall, Conn. (Recent operator, Felix Jordan, Newark, N. J.)

The granite (specimens $\mathrm{D}, \mathrm{XXX}, 60, a, b, c)$ is a biotite-muscovite granite gneiss of medium bluish gray color and of medium inclining to fine gneissose texture, with feldspars to 0.3 inch and mica to 0.1 inch; also with rare porphyritic clear feldspars, the largest 0.4 inch. Its constituents, in descending order of abundance, are clear bluish potash feldspar (microcline and orthoclase) intergrown with quartz that is circular in cross section; clear, colorless quartz; translucent to milk-white soda-lime feldspar (oligoclase) somewhat kaolinized and with calcite; biotite (black mica); muscovite (white mica). Accessory minerals: Ilmenite (probably) surrounded by titanite, apatite, allanite, zircon. Secondary minerals: Calcite, epidote, kaolin, and a white mica. There is a little minute vermicular intergrowth of quartz and feldspar and some granulation of the feldspars. Slight effervescence with cold dilute muriatic acid.

This is a bright bluish foliaceous stone, without marked mineral contrasts.

The quarry is 75 feet square by 10 to 15 feet deep.

Rock structure: Gneiss foliation and rift strike N. $50^{\circ}$ E., and are vertical. The sheets, 2 to 4 feet thick, dip low northwest. There are two sets of joints: Set A, striking N. $60^{\circ}-75^{\circ} \mathrm{W}$., vertical, forms a heading on the south wall and is spaced 20 to 25 feet; set B, striking N. $10^{\circ} \mathrm{E}$., vertical, is spaced 15 feet. The grain is vertical with northwest course. Pegmatite dikes to 2 inches thick strike N. $15^{\circ}$ 
E., and dip $90^{\circ}$ to steep W. Between the quarry and the cemetery on the north side of the road a similar gneiss is in contact with (or contains an inclusion of) a fine-grained biotite gneiss with particles to 1 millimeter, consisting of quartz, biotite, microcline, oligoclaseandesine with accessory apatite, titanite, zircon, and striking $\mathrm{N} .10^{\circ}$ $20^{\circ} \mathrm{E}$.

The plant consists of a hand derrick.

Transportation is by cartage of $4 \frac{1}{2}$ miles to rail at Cornwall Bridge. The product is used for trimmings, for which its foliation and color well adapt it.

LITCHFIELD.

MASCETTI QUARRY.

The Mascetti quarry, $2 \frac{1}{2}$ miles south of Torrington, is in the township of Litchfield, three-fourths mile northwest of East Litchfield village, and on the west side and south end of a knoll rising 480 feet above the village. (See Pl. I.) Operator, Joseph Mascetti, 229 Oak Avenue, Torrington, Conn.

The granite (section $\mathrm{D}, \mathrm{XXX}, 53, a$ ) is a muscovite-biotite granite gneiss of medium inclining to light bluish gray color and of fine gneissose texture, with feldspars under 0.2 inch and mica mostly under 0.1 inch. Its constituents, named in descending order of abundance, are clear bluish potash feldspar (microcline); light smoky quartz with cavities; milk-white soda-lime feldspar (oligoclase) somewhat kaolinized and intergrown with quartz, circular in cross section; muscovite (white mica); biotite (black mica) in smaller flakes, some of it chloritized. Accessory minerals: Garnet (sixth in order of abundance), tourmaline, apatite, zircon. Secondary minerals: Kaolin, calcite, chlorite. The rock effervesces slightly with cold dilute muriatic acid.

This rock is brilliant, with muscovite on its foliation face.

The quarry, opened about 1903, is about 200 feet long, with a 50foot high working face on the east.

Rock structure: Gneiss foliation and rift strike N. $20^{\circ}$ E. and dip $20^{\circ}$. The sheets, 2 to 4 feet thick, dip $20^{\circ}$ and $50^{\circ} \mathrm{NW}$. One set of joints only, strike N. $5^{\circ}$ E., dip $65^{\circ}$ E., spaced 3 to 20 feet, and over. Pegmatite dikes, with black tourmaline and bordered with aplite, 1 to 2 feet thick, meander vertically with a N. $15^{\circ}$ E. course. Others up to an inch thick are parallel to the foliation.

The plant comprises a steam derrick, two hand derricks, a hoisting engine, and steam drill.

Transportation is by cartage of $1 \frac{3}{4}$ miles to East Litchfield, or of $2 \frac{1}{2}$ miles to Torrington.

The product is used for curbing and steps, for which it is well adapted. 
NORFOLK.

CRISSEY QUARRY.

The Crissey quarry is in Norfolk Township, on the southeast side of Bald Mountain, $2 \frac{7}{8}$ miles north-northwest of the village of Norfolk. (See Pl. I.) Owner, R. I. Crissey, Norfolk, Conn.

The granite (specimen $\mathrm{D}, \mathbf{X X X}, 61, a, b$ ) is a biotite-muscovite granite gneiss of medium very slightly greenish gray shade and of even-grained, fine, obscurely gneissose texture with feldspars under 0.2 inch and mica under 0.1 inch. Its constituents, in descending order of abundance, are clear, colorless potash feldspar (micro(cline and orthoclase); clear, colorless quartz, with some cavities in sheets; milk-wlite soda-lime felspar (oligoclase), mostly kaolinized, micasized, and with calcite; biotite (black mica), some of it chloritized; and muscovite (white mica). Accessory minerals: Magnetite, apatite, allanite (rimmed with epidote), zircon. Secondary minerals: Kaolin, calcite, a white mica, epidote, limonite stain. There is some feldspar granulation and also vermicular intergrowth of quartz and feldspar.

The stone effervesces with cold dilute muriatic acid. R. C. Wells, a chemist of the United States Geological Survey, finds that it contains 0.36 per cent of $\mathrm{CaO}$ (lime), soluble in warm dilute (10 per cent) acetic acid, which indicates a content of 0.64 per cent of $\mathrm{CaCO}_{3}$ (lime carbonate, calcite).

This is a bright, fine-grained, gray granite, without mineral contrasts and without shade contrasts between cut and polished faces.

The quarry, opened before 1880 , consists of four excavations, the highest and largest of which measures about 150 feet southeastnorthwest, and has a 50 -foot high working face on the northeast.

Rock structure: The sheets, from 6 inches to 5 feet thick (some reported as 7 feet but now covered), dip $10^{\circ} \mathrm{NW}$. and are normal. There are two sets of joints: Set A, striking N. $80^{\circ}$ E., dipping south steep to $90^{\circ}$, forms the northwest and southeast walls; set B, striking N. $20^{\circ}$ E., vertical, discontinuous, is spaced 5 feet or more. The rift is reported as about horizontal, but the rock splits southeast-northwest.

Transportation is by cartage of a mile to Central New England Railroad.

The product was used for buildings, monuments, and coping. Specimens: Chapel of Congregational Church and the railroad station at Norfolk; the Egbert T. Butler and Anson Gaylord monuments, in Norfolk Center Cemetery.

This quarry, originally opened for coping for the Hoosac Tunnel, in Massachusetts, was closed in 1893, owing to a difficulty with the railroad as to freight rates. 
ROXBURY.

ROCKSIDE QUARRY.

The Rockside quarry is in Roxbury Township, on the east side of Mine Hill, four-fifths mile north of Roxbury Station. (See Pl. I.) Operator: Mine Hill Quarry Co., Roxbury Station, Conn.

The granite (specimen $\mathrm{D}, \mathrm{XXX}, 57, a$ ) is a muscovite-biotite granite gneiss of medium bluish gray color and of fine-grained, even, unplicated, gneissose texture, with particles under 0.2 inch and conspicuous white mica along its foliation. ${ }^{1}$ In thin section the particles, aside from muscovite, range from 0.11 to about 2 millimeters. Its constituents, in descending order of abundance, are bluish translucent potash feldspar (mostly microcline with some orthoclase), slightly kaolinized; clear, colorless quartz with cavities in sheets, one conspicuous set with cracks parallel to it, another less abundant at right angles to the first; muscovite (white mica); whitish soda-lime feldspar (oligoclase; the stone of an upper opening shows oligoclase to oligoclase-andesine) somewhat kaolinized and micasized; biotite (black mica). Accessory minerals: Apatite rather abundant, zircon. Secondary minerals: Kaolin, one or two white micas, calcite. No effervescence with muriatic-acid test.

The quarry, opened in 1890, measures about 800 feet northeastsouthwest by 275 feet across, with a working face on the northwest side measuring in height 35 to 75 feet. The stripping consists of 4 to 5 feet of sand. Another quarry, now disused, near the top of Mine Hill, owned by the same firm, was begun in a small way in 1850 .

Rock structure: The gneiss foliation dips gently southeast on the outer east side of the quarry but $15^{\circ} \mathrm{S} .20^{\circ} \mathrm{W}$. at the working face, tending to become horizontal within the hill. The sheets, from 4 inches to 18 feet thick, correspond to the foliation. The upper 30 feet of the working face consists of thin sheets. There are two sets of joints. Set A, striking northwest and vertical, forms a heading at the southwest wall; another, 6 to 8 feet wide, is 200 feet northeast of that wall; and another, 3 feet wide, is 300 feet farther northeast. The rock left unquarried about these two headings is about 50 feet wide. These joints are spaced 2 to 20 feet. Set B, striking northeast, dips $7^{\circ} \mathrm{NW}$. One of these is 50 feet below the rock surface, another 25 feet lower. The rift corresponds to the foliation. The grain is reported as striking N. $35^{\circ}$ E. and dipping $85^{\circ}$ $\mathrm{S} .55^{\circ} \mathrm{E}$., and the hardway as vertical, with $\mathrm{N}$. $55^{\circ} \mathrm{W}$. course.

1 Prof. W. H. Hobbs regards the muscovite as secondary and formed at the time of the foliation. He also describes the feldspars as crushed and granulated. See Rice and Gregory, Bull. Connecticut Geol. and Nat. Hist. Survey No. 6, p. 110. 
There are white aplitic dikes, from 0.12 to 8 inches thick, almost parallel to the foliation. These are very quartzose, without biotite and with rare muscovite. Some of this aplite is very light gray to white and of even-grained very fine granitic texture, with feldspar and light smoky quartz under 0.1 inch and the finer particles between 0.05 and 0.56 millimeter. It effervesces with cold dilute muriatic acid. Some of these dikes have oligoclase-albite and microcline in about equal parts. Smoky quartz veins, the largest 0.25 inch thick, run parallel to them. Others have a gneissose texture and show quite a little muscovite, evidently secondary and forming "membranes covering the foliation "planes," as described by Prof. Hobbs. The main gneiss is also crossed by dikes of rose-colored aplite from 0.5 inch to 4 feet thick, dipping, like the joints of set. B, $7^{\circ} \mathrm{NW}$. One of these consists chiefly of oligoclase-andesine with crush borders, smoky to amethystine quartz and a little micrccline, rare muscovite but no biotite, in places with microscopic garnets. All its particles are under 0.1 inch. One of the smaller dikes contains microcline, quartz, a little albite, garnet, muscovite, apatite, named in descending order of abundance. Its feldspars are under 0.05 inch and its quartz particles up to 0.2 inch.

Within the second heading from the south end is a mineral vein up to 8 inches thick, which tapers out horizontally at a point 200 feet from the east side of the quarry. It contains pyrite, chalcopyrite, siderite, galenite, and secondary quartz coating crystals of siderite. Similar veins occur in the first and third headings. These are evidently all related to the larger siderite vein which was formerly mined on the hill and.to which it owes its name. Away from the headings the gneiss has little, if any, rusty stain.

The plant comprises two 25 -ton derricks, ten 3 to 8 ton ones, ten hoisting engines, a 10-ton locomotive crane, an air compressor (capacity, 1,128 cubic feet of air per minute), two large air rock drills, sixteen air plug drills, and two surfacers, besides another derrick at the idle quarry.

Transportation is by siding from the Litchfield branch of the New York, New Haven \& Hartford Railroad.

The product is used chiefly for buildings and railroad bridges, and the waste blocks, with aplite or other blemishes, for retaining walls. The stone is sought after because of its color and low price. Specimens: Four rock-faced houses, corner Seventy-second Street and Tenth Avenue, and the retaining wall of the New York Central \& Hudson River Railroad, extending from Sixty-seventh to Seventysecond streets, New York. The length of this wall is 1,350 feet, height, 58 feet; width of base at Seventy-second Street, 21 feet. 
THOMASTON.

PLYMOUTH QUARRY.

The Plymouth quarry is in Thomaston Township, about $1 \frac{1}{2}$ miles south of Thomaston village and nearly half a mile north of Reynolds Bridge. (See Pl. I.) Operator, Plymouth Quarry Co., Thomaston, Conn.

The granite (specimen $\mathrm{D}, \mathrm{XXX}, 54, a$ ) is a quartz monzonite of medium bluish gray color (a trifle lighter and more bluish than Concord granite) and of even grained fine granitic texture, with feldspars and mica up to 0.1 inch. Its constituents, named in descending order of abundance, are light smoky quartz, with hairlike crystals of rutile and cavities in sheets; translucent bluish soda-lime feldspar (oligoclase), some of it micasized and kaolinized; clear colorless potash feldspar (microcline and orthoclase) biotite (black mica); muscovite (white mica). Both feldspars are intergrown with quartz more or less circular in cross section. Accessory minerals: Apatite, rutile. Secondary minerals: Kaolin, a white mica. No effervescence with muriatic-acid test.

This is a bright fine-grained monumental granite which is without mineral contrasts, but which cuts and hammers light. Prof. Newberry, in 1884 , referred to the adaptation of this stone to monumental work. ${ }^{1}$

The quarry measures about 200 feet from north to south by 50 feet across; with a working face (20 to 40 feet high) on the east. The firm is said to have another opening higher up on the ridge.

Rock structure: The granite is capped by 10 to 20 feet of quartz monzonite gneiss, gray or consisting of white feldspar and quartz bands, 0.2 to 0.3 inch wide, alternating with black bands of biotite less than 0.05 inch wide. The constituents of this gneiss, named in descending order of abundance, are light smoky quartz with cavities; milk-white oligoclase; whitish orthoclase; biotite and a little muscovite or bleached biotite. Accessory minerals: Magnetite, apatite, titanite. Secondary minerals: Kaolin, a white mica. This gneiss is intricately plicated. In places its foliation is abruptly intersected by the granite. The boundary between the two rocks is very irregular and pegmatite occurs along part of it. A tapering inclusion of the gneiss, 10 feet by 14 inches or more long and 3 feet wide, occurs 8 feet below the contact. The sheets, from 6 inches to 3 feet thick, dip gently west, but are less regular in the gneiss capping. There are two sets of joints: Set A, striking N. $35^{\circ}$ E., vertical, is spaced 8 to 30 feet, continuing into the gneiss; set B, striking N. $80^{\circ}$ W., vertical, is spaced 3 to 10 feet or more.

The plant comprises a derrick and small hoisting engine. 
Transportation is by short siding, the quarry being but a few feet east of the New York, New Haven \& Hartford Railroad.

The product is used for monuments. The quarry was not in operation in August, 1908, although a few blocks had been recently cut.

TORIINGTON.

COSTELLO QUARRY.

The Costello quarry is in the township of Torrington, $2 \frac{1}{2}$ miles northwest of Torrington and 550 feet above it. (See Pl. I, p. 8.) Operator, Martin B. Costello, R. F. D., Torrington, Conn.

The granite (specimen $\mathrm{D}, \mathbf{X X X}, 50, a$ ) is a muscovite-biotite granite gneiss of medium gray faintly buff shade and of fine, very gneissose texture, with feldspars under $0.2 \mathrm{inch}$, but with larger micas conspicuous on the foliation face and with sparse garnets to 0.2 inch. Its constituents, named in descending order of abundance, are creamcolored potash feldspar (microcline), intergrown with quartz that is more or less circular in cross section; light smoky quartz with cavities in sheets; cream-colored soda-iime feldspar (oligoclase-albite to albite); muscovite (white mica); biotite (black mica). Accessory minerals: Garnet, apatite. Secondary mineral: Limonite.

The quarry, opened in 1898 , measures about 250 feet in a N. $60^{\circ} \mathrm{E}$. direction by 50 feet across and 25 feet in depth.

Rock structure: The foliation strikes N. $50^{\circ}$ E. and dips $55^{\circ}$ N. $35^{\circ}$ W. The sheets, from 8 to 12 feet thick (exceptionally, near the surface, 1 foot thick), are horizontal or inclined to $30^{\circ} \mathrm{NNW}$. There are two sets of joints: Set A, striking N. $30^{\circ}$ E., dipping $30^{\circ}$ to $70^{\circ}$ N. $60^{\circ} \mathrm{W}$., is spaced 8 to 10 feet; set B, striking N. $20^{\circ}$. W., dipping $70^{\circ} \mathrm{N} .70^{\circ} \mathrm{E}$., forms a heading at the west end and is spaced over 100 feet. The rift corresponds to the foliation, and there is little aifference between the grain and the hardway. Garnetiferous pegmatite dikes are up to 2 inches thick. There is little or no rusty stain on sheet surfaces.

The plant comprises one horse derrick, one hand derrick, two steam derricks, two hoisting engines, and a steam pump.

Transportation is by cartage of 3 miles to Torrington or of 11 miles to Winsted.

The product is used for building, trimming, and curbing: Specimens: Parish house of Third Congregational Church, Torrington, entire; Winsted Hosiery Co.'s office, Winsted, entire; trimmings on public library, Winsted; trimmings on factories of Standard Manufacturing Co. and of Union Hardware Co., Torrington.

MICHIEL QUARRY.

The Michiel quarry is in the township of Torrington, more than a mile west of Torrington and 340 feet above it. Operator, Ino de Michiel \& Bro., 352 High Street, Torrington, Conn. 
The granite (specimen $\mathrm{D}, \mathrm{XXX}, 52$ ) is a muscovite-biotite granite gneiss of medium inclining to dark bluish gray shade and of medium very gneissose texture, with feldspar to 0.4 inch and large micas, which are very conspicuous on the foliation faces. Its constituents, named in descending order of abundance, are: Translucent bluish potash feldspar (microcline and orthoclase); light smoky quartz with cavities in sheets and cracks parallel thereto, the sheets of cavities passing uninterruptedly from one particle to the next; a little milkwhite soda-lime feldspar (oligoclase) somewhat kaolinized; muscovite (white mica) ; biotite (black mica). Accessory minerals: Garnet, apatite, zircon. Secondary mineral: Kaolin. Both feldspars are intergrown with quartz that is more or less circular in cross section. No effervescence with muriatic-acid test.

The quarry, opened in 1901, is about 150 feet square and 15 to 30 feet deep.

Rock structure: The gneiss foliation is vertical, with N. $35^{\circ} \mathrm{E}$. course. The sheets, from 1 to 14 feet thick, are horizontal in the center of the quarry, curving over gently on the sides. There are two sets of joints: Set A, striking $\supset$ northwest, vertical or dipping steep southwest, is spaced about 20 feet; set B, striking N. $20^{\circ}$ E., dipping steep $\mathrm{N}$. $70^{\circ} \mathrm{W}$., is spaced 50 feet. The rift corresponds to the foliation, and the grain and hardway are reported as equally pronounced.

The plant comprises a hand and a steam derrick, a hoisting engine, and steam pump.

The product is used mainly for buildings; some for trimming and curbing. Specimens: Methodist Church, Winsted, entire; Italian Catholic Church, Torrington, entire; L. Ripley residence, Litchfield, entire; trimmings on Litchfield library and on the State armory in Meriden, Conn.

TORRINGTON BOROUGH QUARRY.

The Torrington Borough quarry is in the township of Torrington, about $1 \frac{1}{4}$ miles north-northwest of Torrington and several hundred feet above it. (See Pl. I.) Owned and operated by the borough of Torrington, H. I. Holcomb, superintendent, Torrington, Conn.

The granite (specimen $\mathrm{D}, \mathbf{X X X}, 51, a$ ) is a biotite granite gneiss of general dark-gray shade, finely banded with black, and very fine to fine schistose texture, with feldspars under 0.1 inch. Its constituents, named in descending order of abundance, are: Medium-gray potash feldspar (microcline and possibly orthoclase); medium smoky quartz, with cavities in sheets; light-gray soda-lime feldspar (oligoclase), mostly kaolinized and micasized; biotite (black mica); and 
a little muscovite. Accessory minerals: Pyrite, apatite, zircon. Secondary minerals: Kaolin, a white mica, calcite.

Associated with this gneiss is a mica diorite gneiss (specimen D, XXX, 51, $b$ ), a heavy black rock of fine schistose texture. Its constituents, named in descending order of abundance, are: Biotite (black mica); smoky quartz, with cavities in sheets; green hornblende; soda-lime feldspar (andesine), with accessory pyrite (fifth in order of abundance); apatite; and secondary calcite. It has veinlets of quartz under a millimeter.

Both biotite gneiss and diorite gneiss are crossed by meandering dikelets from under 1 inch to 6 inches thick of (specimen D, XXX, $51, c)$ a quartz monzonite gneiss of medium bluish-gray color and fine gneissose texture, with feldspar, under 0.1 inch and very fine micas. Its constituents, named in descending order of abundance, are: Light smoky quartz with cavities in sheets and cracks parallel thereto; milk-white soda-lime feldspar (oligoclase-andesine), some of it kaolinized, micasized, and with calcite; bluish potash feldspar (orthoclase) slightly kaolinized; biotite (black mica); and a little muscovite or bleached biotite.

The quarry measures about 400 feet from northeast to southwest, with a working face from 30 to 65 feet on the northwest.

Rock structure: The foliation of the main gneisses strikes $\mathbf{N}$. $35^{\circ}-40^{\circ}$ E. and dips $45^{\circ}-60^{\circ} \mathrm{W}$. As stated, they are cut by a network of meandering grayish veinlets of quartz monzonite (specimen $c$ ), but they are also crossed by several dikes of pegmatite from 3 to 20 feet thick, the largest and central one of which contains two inclusions of the gneiss measuring 5 by 10 and 2 to 4 by 10 feet. This pegmatite (specimen $\mathrm{D}, \mathbf{X X X}, 51, e$ ) is of medium pinkish gray color and of very coarse texture, with large feldspars and quartz particles up to 0.5 inch. Its constituents are: Reddish microcline and orthoclase, but slightly altered; amethystine quartz with cavities in parallel sheets and cracks parallel and at right angles thereto; a little oligoclase, much micasized and kaolinized; muscovite; biotite. There are crush borders about the feldspars. There are two sets of joints: Set A, striking northeast, vertical, forms a heading near the outside of quarry; set B, striking N. $70^{\circ} \mathrm{W}$., dipping $55^{\circ}$ and $30^{\circ} \mathrm{S} .20^{\circ} \mathrm{W}$, is spaced 3, 30, and 100 feet. Both sets are slickensided.

The plant consists of a large stone crusher, with meshes of onehalf, three-fourths, 1 , and $1 \frac{1}{2}$ inches.

The product is used entirely for macadamizing roads in the borough of Torrington. As little as possible of the pegmatite is used, and that is mixed with the gneisses. Tailings are used in the subgrade. 
WARREN.

COMSTOCK PROSPECT.

The Comstock prospect is in the township of Warren, a mile northnortheast of Warren village and $2 \frac{1}{4}$ miles east of North Kent. (See Pl. I.) Owner, Reuben Tree Voss, 26 Frankfort Street, New York.

The granite (specimen D, XXX, 59, $a$ ) is a biotite granite of medium gray shade and of medium inclining to fine texture, with feldspars to 0.2 and 0.3 inch and mica to 0.2 inch. Its constituents, named in descending order of abundance, are clear, colorless potash feldspar (microcline); pale, smoky quartz, with some cavities in sheets; milk-white soda-lime feldspar (oligoclase), a little kaolinized; biotite (black mica); and a little muscovite or bleached biotite. Secondary minerals: Kaolin and limonite. Both feldspars are intergrown with quartz circular in cross section or in vermicular form. No effervescence with muriatic-acid test. The specimen, coming from a long-exposed upper sheet, hardly does justice to the stone.

The opening, made a number of years ago, is 100 feet square and up to 5 feet deep.

Rock structure: The sheets, from 6 to 14 inches thick, are horizontal. There is a 12-inch pegmatite dike on one side. The exposed surfaces are speckled with limonite stain.

Transportation is by cartage of 3 miles to North Kent, on the New York, New Haven \& Hartford Railroad.

\section{MIDDLESEX COUNTY.}

MIDDLETOWN.

BENVENUE QUARRIES.

The Benvenue quarries are in the township of Middletown, about $4 \frac{1}{2}$ miles east-southeast of the Middletown railroad station, on the mass south of the bend in. Connecticut River and from 200 to 350 feet above it. The nearest railroad stations are Benvenue and Maromas, a mile and half a mile from the openings. (See Pl. I, p. 8.) Owner, Benvenue Granite Co., 41 Park Row, New York.

The granite (specimen D, XXX, 29, a, "Maromas granite gneiss," No. 30, of the State preliminary geologic map) is a biotite-hornblende granite gneiss of dark bluish gray color and of fine-grained gneissose texture, with porphyritic feldspars up to 0.3 inch and mica up to 0.1 inch. Its constituents, in descending order of abundance, are: Bluish translucent potash feldspar (microcline and orthoclase); clear, colorless quartz, showing effects of strain and with cavities in sheets; milk-white soda-lime feldspar (oligoclase) somewhat kaolinized; biotite (black mica) ; and hornblende.. Accessory minerals: Pyrite, magnetite, titanite, apatite, allanite, zircon. Sec- 
ondary minerals: Kaolin, epidote. No effervescence with muriaticacid test.

Twelve crushing tests made on 2-inch cubes of this granite by Ira $\mathrm{H}$. Woolson, M. E., show an ultimate compressive strength ranging from 29,400 to 34,075 pounds per square inch. ${ }^{1}$

This is a bright, somewhat foliaceous bluish gray stone, with strong mineral contrasts.

The Benvenue quarry, about a mile southeast of Benvenue station, and half a mile southwest of Maromas, and 200 feet above the river, measures about 4.00 feet from north to south by 200 feet across, and is from 10 to 60 feet deep. The stripping of sand is up to 8 feet thick. The upper quarry, three-fourths of a mile south-southeast of Benvenue station and 350 feet above the river, measures about 300 feet from east to west by 75 feet from north to south, with a working face on the south ranging in height from 40 to over 60 feet.

Rock structure: At the Benvenue quarry the gneiss foliation strikes northwest and dips $10^{\circ}-20^{\circ} \mathrm{SE}$. The elongation of the gneiss is in a $N$. $65^{\circ} \mathrm{E}$. direction. The sheets, from 6 inches to 6 feet thick, $\operatorname{dip} 10^{\circ}-20^{\circ} \mathrm{E}$ : There are two sets of joints: Set A; striking N. $10^{\circ} \mathrm{E}$., and dipping vertical to $70^{\circ} \mathrm{E}$., forms a 10 -foot heading on the west side, and is spaced 5 to 20 feet; set $\mathrm{B}$, discontinuous, with strike east-west, and dip vertical to steeply south, forms a 10 -foot heading 100 feet from the east end, and is spaced 5 to 20 feet. The rift corresponds to the foliation; the grain is vertical, east-west, and the hardway vertical north-south. Dikes of white to rose colored aplite, 1 to 12 inches thick, strike N. $80^{\circ}-90^{\circ}$ W., dipping $20^{\circ}-35^{\circ}$ $\mathrm{N}$., also strike N. $35^{\circ} \mathrm{W}$, and are vertical. Its particles, under a millimeter, consist of quartz; orthoclase, and microcline, oligoclase, scarce biotite, with accessory pyrite, titanite, and allanite. There are pegmatite dikes of smoky quartz bordered with alternating streaks of oligoclase with microcline and hornblende, up to 3 inches thick, striking N. $75^{\circ}$ E. and dipping $35^{\circ} \mathrm{N}$. $15^{\circ} \mathrm{W}$. There are also dark-gray elliptical segregations from 2 inches to 3 feet long by 0.5 to 8 inches wide, tapering in the direction of the gneiss foliation. The minerals of these segregations in descending order of abundance are, microcline with orthoclase, quartz, biotite, oligoclase, hornblende, with accessory apatite, titanite, and zircon. Brownish limonite stain measures up to 6 inches thick on sheet surfaces. ${ }^{2}$

The rock structure at the upper quarry is like that at the Benvenue quarry.

Product: In 1908 the company was abandoning these quarries because of their numerous joints, knots, and dikes. Its large plant

\footnotetext{
${ }^{1}$ Day, Wm. C., Stone: Righteenth Ann. Rept. U. S. Geol. Survey, pt: 5 (continued), 1897, pp. 959,960 .

2 For a description of the gneiss of this quarry and its structure see Westgate, Lewis G. ; A granite-gneiss in Central Connecticut: Jour. Geology, vol. 7, 1899, pp. 638-654.
} 
was being transferred to a quarry on the west side of Crotch Island, in Stonington, Me., which the company opened in 1906-7, and where the sheet structure is remarkably uniform and the granite is relatively free from defects due to geologic accidents.

NEW HAVEN COUNTY.

ANSONIA.

POTTER QUARRY.

The Potter quarry is in Ansonia, about three-fourths mile northnortheast of the center of the village. Operator, William Potter, Rockwood Avenue, Ansonia.

The granite (specimen $\mathrm{D}, \mathrm{XXX}, 45, a$ ) is a muscovite-biotite granite gneiss of medium bluish-gray color, brightly spangled with mica on the foliation faces, and of fine-grained, unplicated, finely gneissose texture, with feldspars not over 0.2 and mostly under 0.1 inch, but with mica to 0.5 inch. Its constituents, in descending order of abundance, are clear, bluish potash feldspar (microcline and less orthoclase); clear, colorless quartz, with cavities in sheets; bluish translucent soda-lime feldspar (oligoclase), slightly kaolinized; muscovite (white mica); biotite (black mica). Accessory minerals: Apatite, garnet. Secondary minerals: Kaolin, calcite. It effervesces with cold dilute muriatic acid.

The stone glistens brightly with mica on its foliation face, but its other two sides are bluish gray without contrasts. Its foliation adapts it for all uses requiring long, flat stones.

The quarry, opened about 1890 , measures' about 200 by 150 feet, and is from 10 to 50 feet deep, with a working face on the northwest 50 feet high. The stripping consists of 3 feet of sand and loam.

Rock structure: Foliation and rift strike N. $35^{\circ}$ E. and dip $45^{\circ}$ $\mathrm{S} .55^{\circ} \mathrm{E}$. The sheets, 6 inches to 4 feet thick and normal, nearly coincide with the foliation. There are three sets of joints: Set A, striking north, vertical, spaced 10 to 30 feet, forms a heading at the west wall, one (20 feet wide) 40 feet from the northeast wall, and another at that wall; set $B$, striking east-west, vertical, and discontinuous vertically, is spaced very irregularly, 3 to 5 feet or more; set C, striking N. $75^{\circ}$ E., dipping $30^{\circ} \mathrm{N}$. $15^{\circ} \mathrm{W}$., discontinuous vertically, occurs at rare intervals. There are several pegmatite dikes, the largest a foot thick. A vertical dike striking $\mathrm{N}$. $15^{\circ}-22^{\circ} \mathrm{W}$. crosses the entire quarry. A group of such dikes, 2 feet wide, has a like course, and one of these sends a branch westward. The pegmatite consists of quartz, feldspar, muscovite, and black tourmaline. Rusty stain occurs up to 6 inches thick on the lower sheet surfaces. 
The plant comprises two derricks, two small hoisting engines, two air compressors (capacity 40 and 80 cubic feet of air per minute), three air plug drills, a deep-hole air driller, large rock drill, and steam pump.

Transportation is by cartage to Ansonia.

The product is used for curbing, crosswalks, steps, coping, and supplies mostly local demands. The Holbrook quarry in Seymour is on the same belt of rock.

DAVIDSON QUAARY.

The Davidson quarry is on Wakelee Avenue; in Ansonia, on the west side of Naugatuck River. Operator, Ansonia Trap Rock Co., 273 Wakelee Avenue, Ansonia, Conn.

The granite ("Prospect porphyritic 'gneiss," No. 9, of the preliminary State geologic map) is a biotite granite gneiss of darkgray shade and of medium texture, with porphyritic milk-whitish feldspars up to 1.5 inches by 0.5 inch, many of them twins.

The quarry measures about 200 feet in a northwest direction by 40 feet across and 40 feet in depth.

The gneiss foliation strikes about northeast and dips steeply southeast. A 30-foot diabase dike crosses the gneiss parallel to its foliation.

The plant consists of a stone crusher with meshes of one-half, $1 \frac{1}{2}$, 2 , and $2 \frac{1}{2}$ inches in diameter.

The gneiss is crushed for concrete.

BRAN FORD.

NORCROSS QUARRY.

The Norcross quarry is in the township of Branford, about $1 \frac{1}{4}$ miles north of Stony Creek village. (See Pl. I, p. 8, and fig. 3, p. 80.) Operators, The Norcross Bros. Co., Worcester, Mass.

The granite (specimens D, XXIX, $93, a$, rubbed; $b, c$, polished; $g$, rough, "Stony Creek granite gneiss," No. 33, of the State preliminary geologic map), "Branford red granite," is a biotite granite gneiss of medium reddish-gray color and of very variable but mostly from medium to coarse, not porphyritic, gneissoid texture, with feldspars from 0.1 to 0.3 and even 0.8 inch and mica to 0.2 and 0.3 inch. Its constituents, in descending order of abundance, are reddish potash feldspar (microcline, some intergrown with plagioclase, and less orthoclase) somewhat kaolinized, some micasized, and some bent; medium smoky or smoky amethystine quartz, showing effects of strain and with cavities in streaks and sheets; milk-white or greenish-white to cream-colored soda-lime feldspar. (oligoclase to oligoclase-andesine) 
kaolinized and micasized and with more or less calcite; biotite (black mica), some of it chloritized, and a little muscovite or bleached biotite. Accessory minerals: Magnetite, pyrite, apatite, zircon. Secondary minerals: Kaolin, white micas, calcite, epidote, zoisite, chlorite, limonite. Both feldspars are intergrown with quartz more or less circular in cross section. The stone effervesces with cold dilute muriatic acid.

A specimen of the finer parts (D, XXIX, 93, $j$ ) shows feldspar to 0.1 inch and constituents identical with those given above. A specimen of the extra coarse (pegmatitic) parts (D, XXIX, 93,e) shows

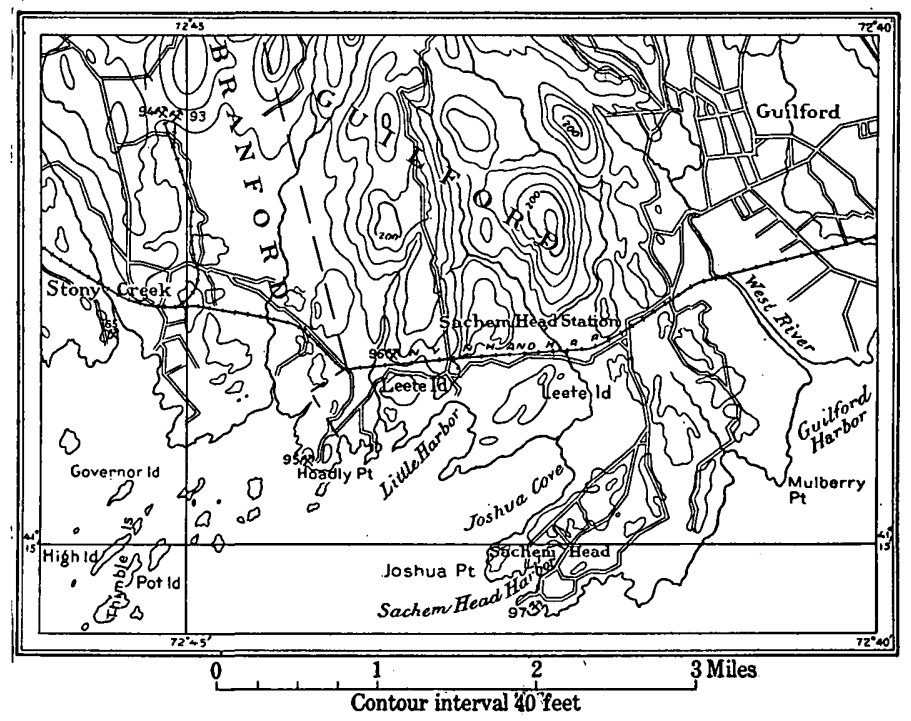

Figure 3.-Map of Branford and Guilford granite quarries: 65 , Brooklyn quarry ; 93, Norcross; 94, Stony Creek; 95, Hoadly Neck; 96, Leete Island; 97, Sachem Head.

feldspars to 1 and 1.5 inches. Its constituents are the same as of the others, but the microcline is more dominant and the rock therefore a little more pinkish.

A compression test made at the United States arsenal at Watertown, Mass., No. 6763, gives this granite an ultimate compressive strength of 22,447 pounds per square inch, rift and grain directions not recorded. Gillmore gave its specific gravity as 165.4 and its ratio of absorption as $1.201 .^{1}$

1 Gillmore, Q. A., Report on compressive strength, etc., of various kinds of building stone from different sections of the United States, etc., Engineer Dept., U. S. Army, Washington, 1874, p. 12. 
The following analysis was made for the firm by Leonard P. Kinnicutt at the Worcester Polytechnic Institute in 1890:

Analysis of biotite granite gneiss from Stony Creek.

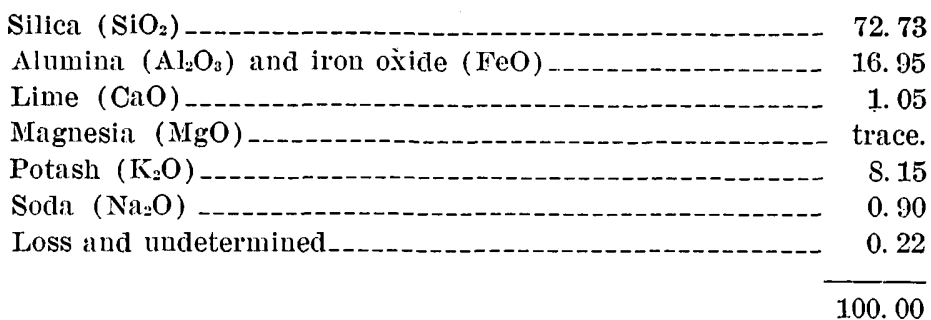

The marked feature of this rock is its very irregular texture, which is due in part to pegmatitic injection, in part to flow structure, and in part probably to gneissic foliation. These irregularities are shown in the polished slab shown in Plate III, $A$, page 48. In places the rock is a flow gneiss; in others a pegmatite; in others it approaches an aplite in fineness. It is a brilliant stone. Its mineral contrasts lie chiefly between the reddish and whitish feldspars, but these are not everywhere distributed in their normal proportions. It takes a fair polish. The polished face shows some magnetite, some mica, and a little pyrite, and is therefore less suitable for outdoor than indoor use. That its strength and attractive color have more than counterbalanced its irregularity of texture is evidenced by the important structures in which it has been used.

The quarry, begun in 1887, consists of a lower opening and an upper one 100 feet north of it. The lower one measures about 450 . feet north to south, by 200 feet across, and is from 15 to 65 feet deep; the upper one, about 500 feet north to south, by 100 feet, and $15-40$ feet in depth.

Rock structure: The sheets, from 2 to 25 feet thick, are horizontal or inclined $10^{\circ}-20^{\circ}$ SE. ${ }^{1}$ There are two sets of joints. Set A, striking east to west, vertical or steep, is spaced 5-75 feet. In the upper quarry these are confined to the southern 100 feet of the quarry, where their spacing is 5 to 20 feet. Set B, striking N. $10^{\circ}$ E. and N. $5^{\circ}-15^{\circ} \mathrm{W}$., vertical, forms a 5 -foot heading on the east side of the lower quarry, and, extending through the upper one, is spaced 10 to 40 feet. The flow structure, consisting of more or less biotitic or nonbiotitic bands, strikes $\mathrm{N}$. $70^{\circ} \mathrm{W}$, and dips $35^{\circ}-55^{\circ} \mathrm{N} .20^{\circ}$ E. to vertical. A slight gneissic foliation is probably also present, but is obscured by the flow structure and the pegmatite. Traces of that foliation appear under the microscope in the strained quartz,

$1 \mathrm{~A}$ view of the sheet structure here is given in a paper by Prof. J. F. Kemp, Granites of Southern Rhode Island and Connecticut [etc.] : Bull. Geol. Soc. America, vol, 10, 1899, 
bent feldspars, and veinlets of secondary muscovite. The rift is reported as horizontal in the upper quarry and dipping $3^{\circ}-5^{\circ}$. W. in the lower, and the grain as vertical with $\mathbf{N} .20^{\circ}-30^{\circ} \mathrm{W}$. course. A few inches of "shake structure" occur along the sheet surfaces. Both knots and inclusions occur. A microscopic description of a knot, from the neighboring quarry of the Stony Creek Red Granite Co., is given on page 83. Inclusions range from 2 by 1 foot and under to 8 by 3 by 1 foot. One of these (specimen D, XXIX, 93, $h$ ) is a black schistose rock with particles under 0.1 inch and consists, in descending order of abundance, of hornblende, andesine, biotite with muscovite, quartz and accessory titanite, magnetite, or ilmenite, It. is a quartz-mica diorite gneiss. A medium gray gneissoid one (specimen D, XXIX, 93, $i$ ) with particles under 0.1 inch consists, in like order, of oligoclase-andesine, quartz, biotite with accessory zircon; and thus is a mica diorite gneiss. Still others (specimens 93, $k, k k$ ) are a dark-gray fine-grained quartz-mica diorite gneiss with oligoclase, quartz, and biotite, and accessory pyrite, magnetite, apatite, titanite, and zircon. The coarser feldspars are zonally arranged about some of the inclusions; that is, they have a pegmatitic border. One inclusion is rimmed with biotite.

The plant comprises 11 derricks, including one of 35 tons, 11 hoisting engines, a 20 -ton overhead traveling crane, 8 hand derrick cars, 2 locomotives, a 30-horsepower dynamo for polishers, lathes, and lighting, 5 steam drills, 2 air compressors (capacity 700 and 200 cubic feet of air per minute), 14 air plug drills, 15 air hand tools, 5 surfacers, a gang of saws for stones 15 feet by 6 feet, 5 polishers, 2 sets of double-pendulum polishers for straight molding, a lathe for stones 19 feet by 3 feet 6 inches, 2 for stones 8 feet by 2 feet, 3 polishing.lathes of corresponding sizes, and a steam pump.

Transportation is by siding from New York, New Haven \& Hartford Railroad, as shown in figure 3.

The product is used mostly for buildings and bridges and some for monuments. Specimens: South Terminal Station, Boston; Bessemer Building, Pittsburg; Newberry Library, Chicago; arches and roadway coping of Connecticut River Bridge, Hartford; polished columns (43 feet by 6 feet 2 inches at base) of Battle Monument, West Point; obelisk (45 feet long) at Locks Park, Sault Ste. Marie, American side (see Pl. III, $B$ ) ; pedestals of Sherman statue, Fiftyninth Street and Fifth Avenue, New York; of King Frederick statue, Washington; and of Gen. Hooker statue, State House grounds, Boston.

STONY CREIK QUARRY.

The Stony Creek quarry is in Branford Township, about 13 miles north of Stony Creek village, less than one-fourth mile west-north- 


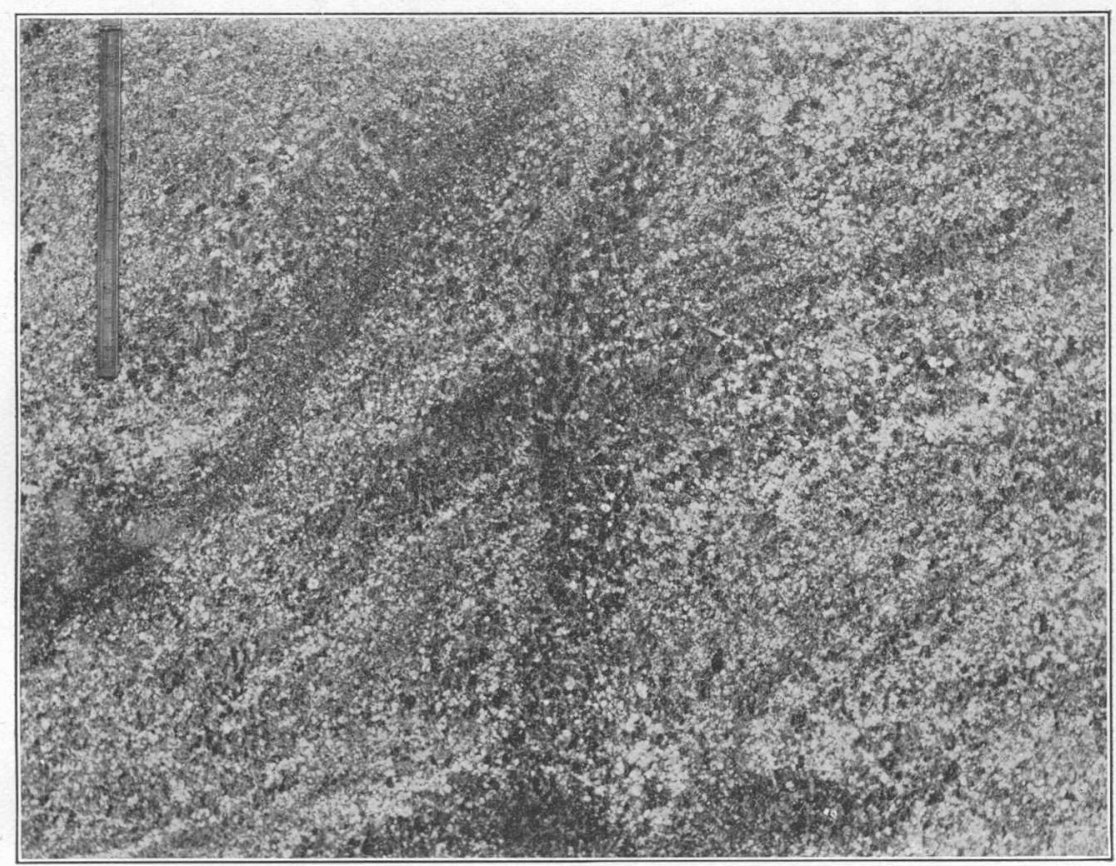

A. POLISHEd SLAB OF PEGMATITIC BIOTITE GRANITE GNEISS ("BRANFORd RED GRANITE ") FROM THE NORCROSS QUARRY AT STONY CREEK.

Showing irregularity in size of particles owing to pegmatization and in their arrangement owing to flow structure and probably also to gneissic foliation. Rule shown is 12 inches long. See page 81 .

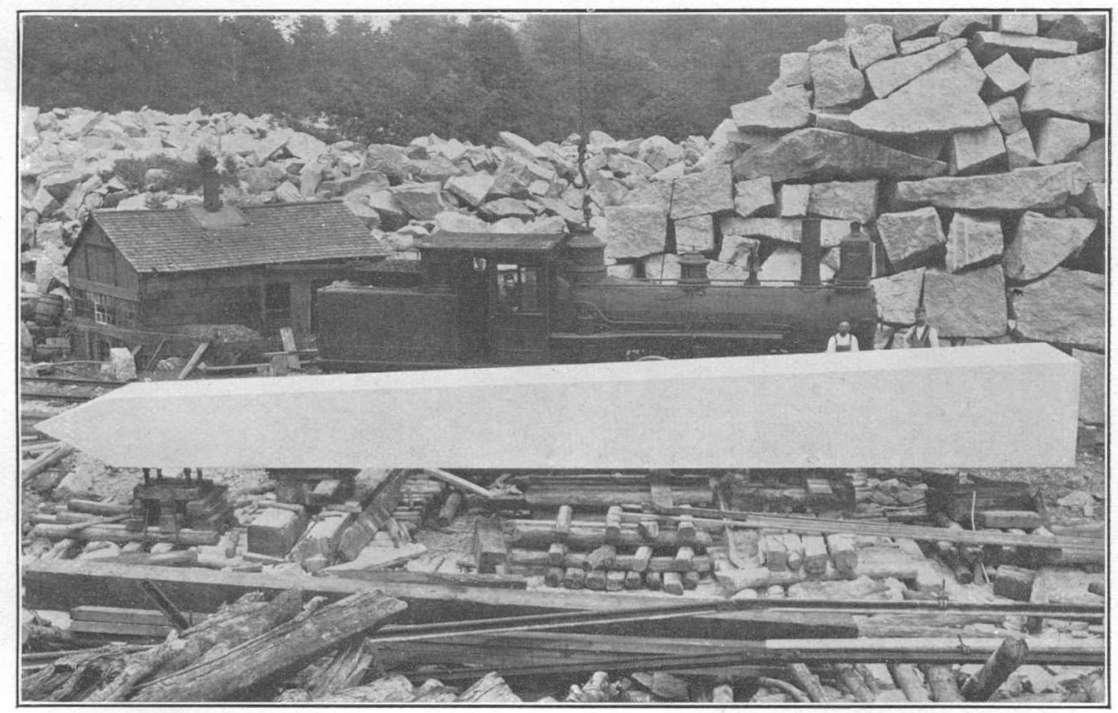

B. OBELISK OF HAMMERED PEGMATITIC BIOTITE GRANITE GNEISS ("BRANFORD RED GRANITE") FROM THE NORCROSS QUARRY AT STONY CREEK. 
west of the Norcross quarry and on the opposite (east) side of the same north-northwest trending ridge. (See fig. 3.) Operator, the Stony Creek Red Granite Co., Stony Creek, Conn.

The granite (specimens D, XXIX, 94, $a, e$, rough and polished, "Stony Creek granite gneiss," No. 33, of the State preliminary geologic map), "Stony Creek red granite," is a biotite granite gneiss of medium to coarse, not porphyritic texture. The stone is identical with that of the Norcross quarry, described on page 79, except that in the average specimen submitted the potash feldspars are more reddish and the soda-lime feldspars are a greenish gray, instead of whitish or cream colored, having evidently retained more of their original color. The effect is to diminish the contrast between the feldspars. The sections also show veinlets of secondary muscovite and calcite in the feldspars and of muscovite in the quartz.

The stone effervesces with cold dilute muriatic acid. R. C. Wells, a chemist of the United States Geological Survey, finds that it contains 0.25 per cent of lime $(\mathrm{CaO})$, soluble in warm dilute 10 per: cent acetic acid, which indicates a content of 0.445 per cent of lime carbonate, calcite $\left(\mathrm{CaCO}_{3}\right)$.

The general characteristics and qualities of the stone are the same as those of the Norcross quarry stone. There is the same irregularity in texture and in the relative proportions of the two feldspars.

The quarry, opened about 1876, consists of two openings, an eastern one measuring about 200 feet in a north-northwest direction by 35 to 50 feet across, with a working face on the east, and a western opening measuring about 400 feet in a north-northwest direction by 75 feet across and from 10 to 30 feet in depth, with a working face on the west. This western opening is about 300 feet south of the other; but on the east side of a ridge about 80 feet high and 300 feet west of that which separates the eastern opening from the Norcross quarry.

Rock structure: The sheets, 2 to 12 feet thick, dip $15^{\circ} \mathrm{WSW}$. There are two sets of joints: Set A, striking N. $60^{\circ}-70^{\circ}$ E., dipping $50^{\circ}-70^{\circ} \mathrm{NNW}$., is spaced $10,15,70$, and 200 feet; set B, striking $\mathrm{N}$. $30^{\circ}-35^{\circ} \mathrm{W}$., vertical, forms a heading, 5 to 10 feet wide, on the working face of the western opening, and is spaced 5 to 40 feet. There is a marked flow structure, consisting of biotitic planes or sheets striking N. $65^{\circ}$ E., and dipping $60^{\circ}-65^{\circ} \mathrm{NNW}$. The rift is reported as horizontal and the grain as vertical with a course $\mathrm{N} .35^{\circ}$ W. . Some of the pegmatite feldspars measure to 1.5 inches. Some irregular lenses of chloritic quartz measure to 12 inches in diameter. A dark-gray fine-grained knot consists, in descending order of abundance, of microcline and oligoclase in almost equal amounts, biotite, and a little quartz, together with accessory magnetite, apatite, zircon. Rusty stain is up to 8 inches thick on sheet surfaces. 
The plant comprises six derricks, two hoisting engines, a locomotive, three steam drills, an air compressor (capacity 525 cubic feet of air per minute), eight air plug drills, twelve air hand tools, and a surfacer.

Transportation is by siding from the New York, New Haven \& Hartford Railroad. The firm owns $2 \frac{1}{2}$ miles of track. (See fig. 3.)

The product is used mostly in buildings, and its chief market is New York and vicinity. Specimens: Broadway Chambers Building, New York Central Railroad, post office, and office buildings, New York; water tower, Brooklyn; Erie County Savings Bank, Buffalo, N. Y.; and First National Bank, New Haven.

BROOKLYN QUARRY.

The Brooklyn quarry, no longer worked, is on the point west of Stony Creek village, in Branford. It was visited by Freeman Ward, instructor at the Sheffield Scientific School, of Yale University, who contributes the following observations:

There are a series of openings, extending 600 or 750 feet about parallel with the shore line, which have not been worked for 10 or 15 years or more.

The sheets range from the horizontal to a dip of $15^{\circ}$. There are six sets of joints : A, striking $19^{\circ} \mathrm{W}$; B, striking N. $49^{\circ} \mathrm{W}$.; C, striking N. $64^{\circ}-69^{\circ} \mathrm{W}$; $\mathrm{D}$, striking N. $79^{\circ} \mathrm{W}$.; E, striking N. $86^{\circ}$ E., and all dipping $75^{\circ}-85^{\circ}$, but one set (E) dips $50^{\circ}-55^{\circ} \mathrm{N}$. A less conspicuous set $(\mathrm{F})$ strikes $\mathrm{N}$. $71^{\circ} \mathrm{E}$. and dips $50^{\circ}-55^{\circ} \mathrm{S} .19^{\circ} \mathrm{E}$. Inclusions of a biotite and of a hornblende gneiss measure up to 36 by 12 feet, but some are thin and slablike. Perhaps some of the biotitic streaks are elongated inclusions. All of the inclusions, especially the large ones, are apt to be well injected with granite, and some of them have segregations of garnets. Pegmatite does not occur in definite dikes but in irregular streaks which have no distinct boundaries and grade imperceptibly into the surrounding granite. This pegmatite has generally the appearance of the typical Stony Creek granite but may be coarser, the maximum size of its feldspars being 3 inches.

The unpegmatized granite (specimen D, XXX, 65, $a$, "Stony Creek granite gneiss," No. 33, of the State preliminary geologic map, collected by Mr. Ward, but examined by the writer) is a biotite granite gneiss, somewhate dark reddish gray in color and of even-grained medium texture, with feldspar to 0.3 inch and mica to 0.05 inch. Its constituents, in descending order of abundance, are pale reddish potash feldspar (microcline and orthoclase), slightly kaolinized; medium smoky quartz, strained and with cavities in sheets; slightly greenish soda-lime feldspar (oligoclase to oligoclase-andesine), more or less micasized and kaolinized; biotite (black mica), some of it chlo- 


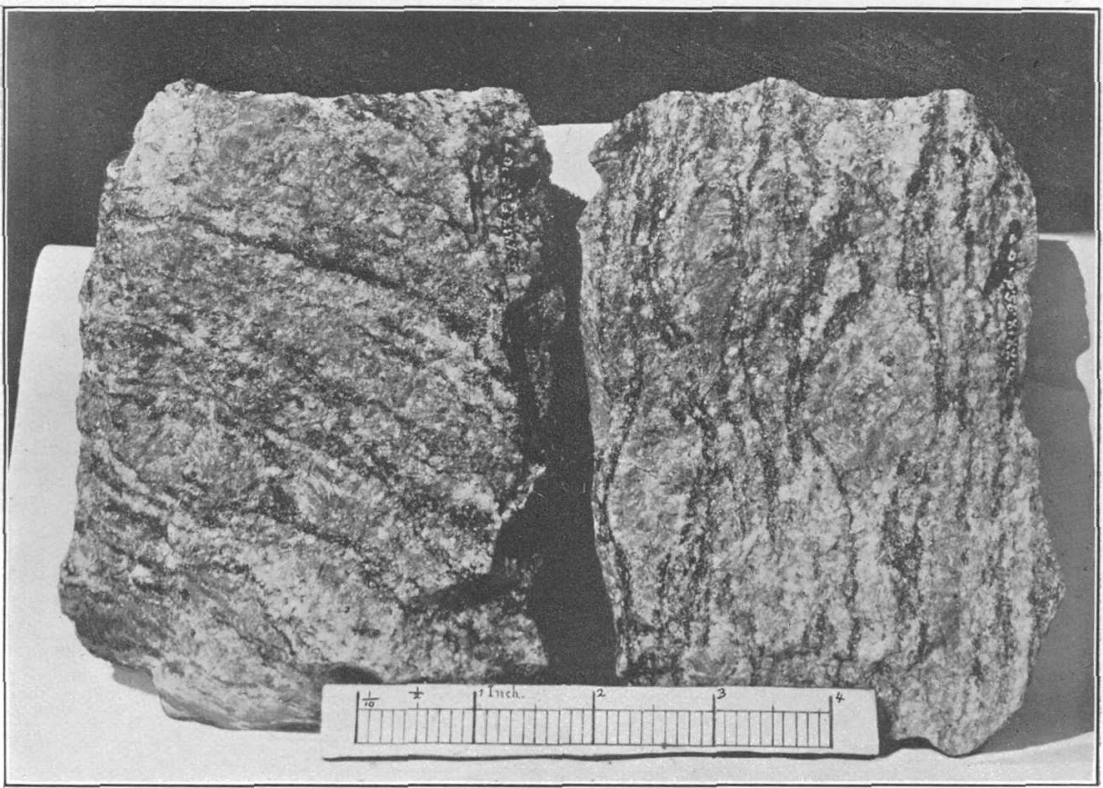

A. COARSE PORPHYRITIC BIOTITE GRANITE GNEISS FROM HOADLY POINT "WEST" QUARRY, BRANFORD,

Showing the lenticular shape of the feldspars and the distribution of the mica and quartz in bands. The large lenses are mostly microcline feldspar. See page 85 .

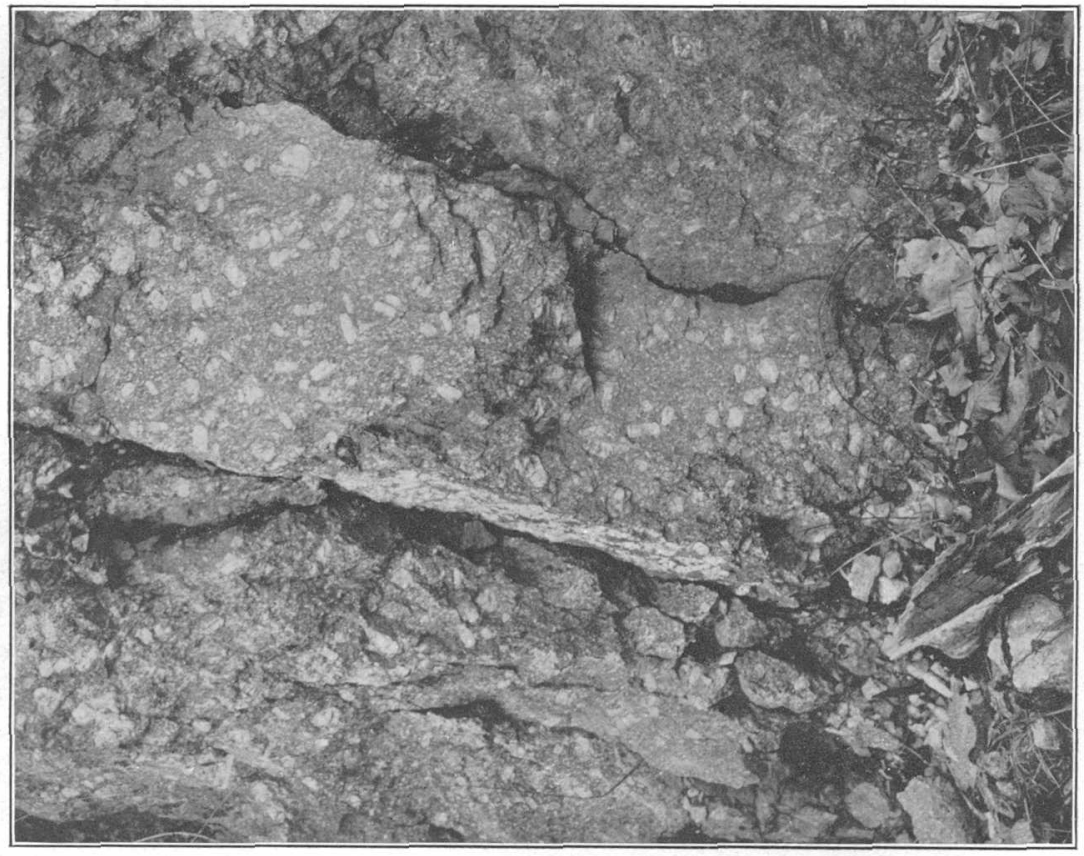

B. PORPHYRITIC GRANITE GNEISS FROM DERBY.

The phenocrysts are feldspar. See page 21. 
ritized, with a little muscovite or bleached biotite. Accessory minerals: Garnet (fifth in order of abundance), pyrite, zircon. Secondary minerals: Kaolin, a white mica, calcite, chlorite. The stone effervesces with cold dilute muriatic acid.

HOADLY NECK QUARRIES.

The Hoadly Neck quarries are in the town of Branford, at the end of Hoadly Point. (See fig. 3, p. 80.) Operator, estate of John Beattie, Peter and John Beattie, jr., executors, Leete Island, Conn.
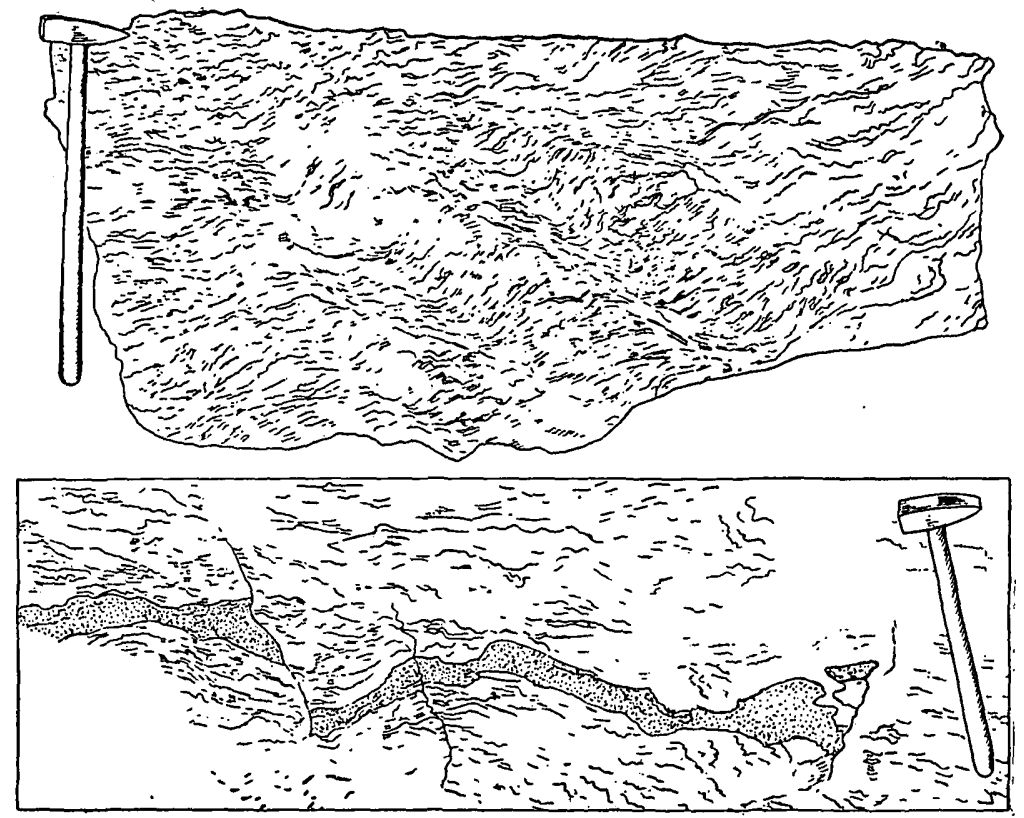

Figure: 4.-Uppel: Block of plicated biotite granite gnelss from West quarry, Hoadly Foint, Branford. Iower: Plicated and faulted band of fine biotite granite gneiss within the coarser gneiss of same quarry. Hammers 20 inches long. (From photographs.)

The granite (specimens D, XXIX, 95, $c, d$, from West quarry, "Stony Creek granite gneiss," No. 33, of the State preliminary geologic map), "Hoadly Neck, West quarry, granite," is a biotite granite gneiss of general medium, inclining to dark reddish gray color, and of coarse to very coarse banded, plicated gneissose porphyritic texture, consisting of reddish gray or whitish lenses and bands alternating with or bordered by thin sheets of black mica and with some thin bands of smoky quartz. The lenses, which are distorted feldspar crystals, commonly twins, measure to 3 inches in length and 1 inch in width, and the mica bands 0.1 to 0.2 inch. The texture as seen in hand specimens is shown in Plate IV, $A$. The foliation is coarsely plicated, the plications up to 10 inches in width, and these are in 
places faulted, as shown in figure 4. The constituents of this biotite granite gneiss, in descending order of abundance, are reddish potash feldspar (microcline, somewhat kaolinized, with some orthoclase); medium smoky quartz, with cavities in sheets; whitish soda-lime feldspar (oligoclase), intergrown with quartz more or less circular in cross-section or in vermicular form, and generally much micrasized; biotite (black mica), some chloritized; a little green hornblende. Accessory minerals: Garnet, pyrite, zircon, apatite. Secondary minerals: A white mica, kaolin, limonite about pyrite, calcite. The stone effervesces slightly with cold dilute muriatic acid.

This stone has marked mineral contrasts and striking textural features, as shown in Plate IV $\dot{A}$. It is a coarse constructional granite gneiss of warm gray tint.

The stone of the East quarry (specimens D, XXIX, $95, l, m$ ) lacks the coarsely banded porphyritic texture of the other. Its color is medium reddish gray and its texture is gneissose, even grained medium, inclining to fine, with feldspars to 0.3 inch and mica under 0.1 inch. Its constituents are the same as the others, but a thin section shows the light feldspar as oligoclase-albite.

The quarry, opened in 1867, consists of two openings-the west quarry, about 1,500 feet east to west by 800 feet across, with a working face from 30 to 70 feet above sea level, and the east quarry, about 2,000 feet long and curving from west to east by 400 feet across, with working face like the other.

Rock structure: In the West quarry there is a plicated gneissic foliation about horizontal, faulted in places with displacement of a few inches. The sheets of that quarry, 2 to 8 feet thick, are horizontal or dip $10^{\circ} \mathrm{NE}$. Those of the East quarry 6 inches to 2 feet thick, turn from the horizontal to $\operatorname{dip} 10^{\circ} \mathrm{E}$. There are three sets of joints in the West quarry: Set A, striking N. $80^{\circ}$ W., vertical, forms a heading at east end, one, 5 to 8 feet wide, through the center, and is spaced 5 to 150 feet; $\mathrm{B}$, striking about northeast, vertical, is spaced 40 to 200 feet; C, striking N. $20^{\circ}$ W., vertical is spaced 10 feet or more. There are two other sets in the East quarry; set D, striking N. $15^{\circ}$ E., dips $77^{\circ}$ E. and is spaced 5 to 10 feet or more; E, striking N. $60^{\circ} \mathrm{W}$., vertical, forms occasional small headings and is spaced 5 to 10 feet. The rift is reported as horizontal and the grain as vertical, with N. $65^{\circ}$ E. course at the West quarry and N. $75^{\circ}$ E. at the East quarry, but the difference in their fissility appears to be slight. Pegmatite dikes (specimen $95, a), 1$ to 3 feet thick, strike N. $20^{\circ}$ E. and N. $45^{\circ}$ E. They consist of the same minerals as the gneiss, but in extra coarse particles. There are dikes or bands of fine biotite granite gneiss up to 4 inches thick. Some of these in the West quarry are parallel to the foliation and have been plicated with it, as shown in figure 4. 
The rock is of merlium pinkish gray color and of very fine to fine gneissose banded texture, with feldspars to 0.1 inch. The bands of the coarse gneiss are reddish or light and dark gray or black, from 0.05 to 0.4 inch wide, and result from the distribution of the various minerals in parallel lamina. The constituents of this gneiss are identical with those of the coarse rock. Allanite is among its accessories. In the East quarry there are dark bands of mica diorite gneiss (specimen D, XXIX, 95, $k$ ) up to 2 feet thick, striking N. $62^{\circ}$ E. and dipping $75^{\circ}$ N. $28^{\circ}$ W., consisting in descending order of abundance of biotite, oligoclase-andesine, green hornblende, and quartz. These are either inclusions elongated in the direction of the flow or more probably altered basic dikes.

The plant comprises 10 derricks, including one of 25 tons; 14 hoisting and drawing engines, an air compressor (capacity 1,000 cubic feet of air per minute), 8 large steam drills, 16 air plug drills, a 12 ton overhead pneumatic crane, 4 surfacers, and a polisher. The plant includes also 7 schooners.

Transportation is either by siding from New York, New Haven \& Hartford Railroad at Leete Island station or by water. There are seven docks near the quarries with 8 feet of water at low tide.

The product is used for massive bridge work, buildings, and monument pedestals. Specimens: Anchorage of Suspension Bridge, Niagara; anchorage of first Brooklyn Bridge; approaches and abutments of Madison Avenue Bridge, Harlem River; piers and abutment of Connecticut River bridge, Hartford; pedestal of statue of Liberty, New York Harbor; of Gen: Anderson Monument, Fort Sumter, S. C.; of Soldiers and Sailors Monument, Riverside Drive, New York. A polished slab of the West quarry stone 6 by 3 feet, exposed for 20 years at a house near the quarries, has stood exposure well, notwithstanding the coarseness of its mica.

GUILFORD.

LEE'TE ISLAND QUARRY.

The Leete Island quarry is in the township of Guilford, about 350 feet north-northeast of Leete Island station on the New York, New Haven \& Hartford Railroad. (See fig. 3.) Operator, estate of John Beattie, Peter and John Beattie, jr., executors, Leete Island, Conn.

The granite (specimen D, XXIX, 96, $a$, "Stony Creek granite gneiss," No. 33, of the State preliminary geologic map), Leete Island granite, is a biotite granite of medium reddish gray color and of granitic or obscurely gneissose even-grained medium texture, with feldspars to 0.25 inch and mica to 0.2 inch. Its constituents, named in descending order of abundance, are reddish potash feldspar (microcline and orthoclase, the latter intergrown with soda-lime 
feldspar), generally fresh; medium smoky quartz with cavities in sheets; cream-colored soda-lime feldspar (oligoclase-albite), micasized, kaolinized, and with calcite; biotite (black mica), some of it chloritized, and a little muscovite or bleached biotite. The microcline is intergrown with quartz more or less circular in cross section. There are crush borders about some of the feldspars and veinlets of muscovite. Accessory minerals: Magnetite and zircon. Secondary minerals: Kaolin, white micas, calcite, chlorite. It effervesces with cold dilute muriatic acid.

This stone resembles that of the Norcross and Stony Creek quarries (pp. 79, 82), but its texture is finer and more regular. Yet it contains here and there some pegmatitic streaks with feldspar to 2 inches across. Whatever apparent gneissic texture it has is due mainly to flow structure.

The quarry is on the southwest side of a knoll and measures about 650 feet from southeast to northwest by 50 to 150 feet across, with a working face on the northeast about 60 feet high but divided by unequal quarrying into an upper 20 -foot and a lower 40 -foot one.

Rock structure: The sheets, from 1 to 6 feet thick, are arched, being level in the center of the hill and dipping to $20^{\circ} \mathrm{W}$. on its west side and $10^{\circ} \mathrm{E}$ on its east side. There is but one set of joints, strike nearly east to west, vertical; spacing, 5 to 100 feet. There are black knots (specimen $96, b$ ) up to 1 by 4 feet, of very irregular outline, of fine-grained black quartz-mica diorite gneiss, consisting (in usual order) of oligoclase, quartz, and biotite, with much magnetite and accessory apatite, and zircon.

The plant comprises two derricks.

Transportation is by siding from the adjoining station.

Product: The quarry has not been worked very recently, because of the cheaper transportation by water afforded by the location of the firm's other quarries. (See p. 85.)

\section{SACHEM HEAD QUARRY.}

The Sachem Head quarry is in the township of Guilford, on Sachem Head, on the south side of Great or Sachem Head Harbor. (See Pl. I and fig. 3.) Operator: Breakwater Co., Hickok Building, Cleveland, Ohio, and 115 Broadway, New York.

The granite (specimens D, XXIX, 97, $a, b, c, d$, "Stony Creek granite gneiss," No. 33, of the State preliminary geologic map), Sachem Head granite, is a biotite granite gneiss of medium more or less reddish gray color and of very variable gneissose texture, ranging from medium inclining to fine, even grained, with feldspars to 0.3 inch, to porphyritic, with a matrix of same character containing isolated reddish-buff feldspars to $0.7 \mathrm{inch}$, and also with 


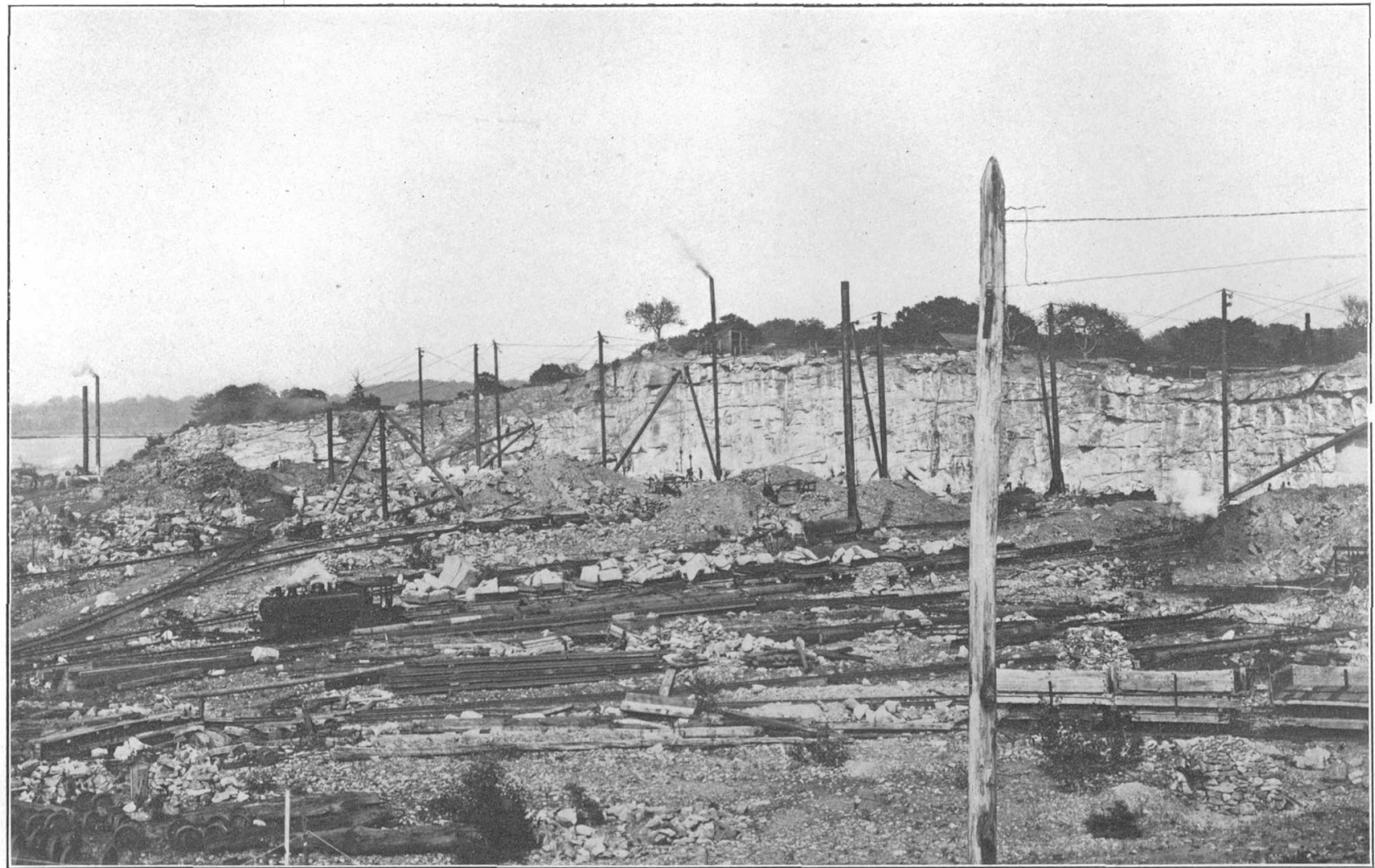

SACHEM HEAD BREAKWATER GRANITE QUARRY, GUILFORD.

Looking northeast, showing the working face of biotite granite gneiss with horizontal sheets, the long drill holes made in blasting off large masses, and the tracks converging to the dock. See page 89. 
pegmatitic streaks with feldspars to 1 inch. The mica is mastly under 0.1 inch and the pegmatitic portions to 0.2 inch. The constituents of this rock, in descending order of abundance, are reddish-buff potash feldspar (microcline and some orthoclase), but slightly kaolinized; medium smoky quartz with cavities in sheets and some cracks roughly parallel thereto; striated milk-white sodalime feldspar (oligoclase-albite) more or less micasized and with calcite; biotite (black mica), some of it chloritized, and very little muscovite or bleached biotite. Accessory minerals: Magnetite, apatite, zircon. Secondary minerals: One or two white micas, kaolin, calcite, hematite, chlorite, epidote. Veinlets of müscovite and also of calcite. Both feldspars are intergrown with quartz, more or less circular in cross section. The stone effervesces with cold dilute muriatic acid.

Gillmore gave the specific gravity of this granite as 163.7 and its ratio of absorption as $1.162 .{ }^{1}$

This is a brilliant granite, with greater variations of shade, color, and texture than those of granite of the Norcross and Stony Creek quarries. The prevalence of "shake structure" has probably prevented its use in buildings and also facilitated its exploitation for other purposes.

The quarry, opened before 1893, has a working face on the east about 1,000 feet long and from 25 to 50 feet high, averaging about 35 feet, which in the course of excavation has receded from 450 to 500 feet. (See Pl. V.)

Rock structure: A flow structure or gneiss foliation strikes N. $70^{\circ}$ E. and curves vertically. The sheets, from 3 to 8 feet thick, are horizontal, as shown in Plate V. There is also a coarse horizontal shake structure spaced 0.5 to 3 inches and even 6 inches. In places these minor sheets are 6 inches thick over the whole face. There are two sets of joints: Set A, striking N. $70^{\circ}$ E., vertical, spaced 200 to 500 feet; set B (one only), striking N. $40^{\circ}-45^{\circ}$ E., dipping $80^{\circ}$. Rusty stain is a foot wide along the sheet surfaces.

The plant comprises fourteen 10-ton derricks, fourteen hoisting engines, two 20-ton locomotives, nine large and five small steam rock drills, two 1,500-ton double. derrick barges, and one dump scow.

Transportation is effected by a system of tracks which, starting near the working face, converge at the dock where the barges are moored. (See Pl. V.)

In quarrying, a line 150 feet long of plain drill holes is made 12 feet back of the working face. The holes are 7 feet apart and up to 30 feet deep, not quite penetrating the lower surface of a sheet.

1 Gillmore, Q. A., Report on compressive strength, etc., of various kinds of bullding stone from different sections of the United States, etc., Engineer Dept., U. S. Army, Washington, 1874 , p. 12. 
After these have been fired a second lower tier of like holes is made, and after these have been fired a third but diagonal set is made at the foot of the wall and inclined toward it. Both dynamite and powder are used. The drill holes are shown in the plate.

The product is confined to riprap for breakwaters. Material for the Point Judith (R. I.) breakwater was supplied from this quarry, and in 1907 it was furnishing stone for the New Haven breakwater.

\section{SEYMOUR.}

HOLBROOK QUARRY.

The Holbrook quarry is in Seymour Township, a mile east of the Naugatuck River, and near the Ansonia line. (See Pl. I, p. 8.) Operators: Seccombe Bros., Ansonia, Conn.

The granite (specimens $\mathrm{D}, \mathrm{XXX}, 46, a, b$ ) is a muscovite-biotite granite gneiss of medium marked bluish gray color, spangled with mica on the foliation face, and of fine-grained slightly plicated finely gneissose texture, with feldspars not over 0.2 inch and mostly under 0.1 inch but with mica to 0.5 inch. Its constituents, in descending order of abundance, are clear bluish potash feldspar (microcline and less orthoclase) ; clear, colorless quartz; bluish translucent soda-lime feldspar (oligoclase) slightly kaolinized; muscovite (white mica); biotite (black mica). Secondary kaolin. No effervescence with muriatic-acid test.

The granite is identical in composition with that of the Potter quarry in Ansonia (p. 78), which lies three-fourths mile south, but this is more markedly bluish. The stone glistens brightly on its foliation face, but its other two sides afford no contrasts. Its foliation adapts it well for all uses requiring long flat stones.

The quarry, opened about 1877, measures about 300 feet from southwest to northeast by 150 feet across, and from 50 to. 70 feet in depth.

Rock structure: The gneiss foliation strikes N. $25^{\circ}-30^{\circ}$ E. and dips $47^{\circ}$ S., $65^{\circ}$ E. The sheets, 2 to 5 feet thick, incompletely developed, $\operatorname{dip} 25^{\circ}-30^{\circ}$ E. There are three sets of joints: Set A, striking N. $75^{\circ}$ W., vertical, forms a heading. at the south wall, a heading 10 feet wide, 75 feet north of it, and is spaced 2 to 30 feet. Set B, strikes N. $25^{\circ}$ E., dips $45^{\circ}-75^{\circ}$ S., $65^{\circ}$ E., and vertical, forms the west wall, and at south end undulates like sheets, and is spaced 3 to 10 and 30 feet. Set C, undulating, strikes N. $30^{\circ}$ E., dips $30^{\circ}$ N., $60^{\circ}$ W.; one at east side. The rift coincides with gneiss foliation and the grain with the same strike dips $25^{\circ} \mathrm{W}$. On the east the gneiss is in contact with an overlying mass of biotite-quartz feldspar schist. (See fig. 5.) This schist (specimens D, XXX, 46,c,d) is more or less intensely 
plicated. In thin section it consists, in descending order of abundance, of quartz, biotite, microcline with orthoclase, pyrite, and garnet. It is probably of igneous origin. Pegmatite (of feldspar, smoky quartz, muscovite and black tourmaline) appears in numerous dikes from 6 inches to 2 feet thick. Of a set striking N. $10^{\circ}-15^{\circ}$ W., there are five spaced 15 to 20 feet. Another set of three striking N. $35^{\circ} \mathrm{E}$. is spaced 10 to 18 feet. There is very little stain.

The plant comprises two 6-ton derricks, a hoisting engine, steam rock drill, steam pump, and stone crusher with capacity of 100 tons a day, and screens with meshes 2 inches, 1 inch, and one-half inch.

Transportation is by cart $1 \frac{1}{2}$ miles to railroad at Ansonia.

The product is used for curbing, circulars, marking, and hitching posts, cross walks, trimmings and concrete for local demands. Specimens: Trimmings on Fountain Hose Fire. Co. building, Ansonia, and on St. Francis Parochial School, Naugatuck, Conn. The

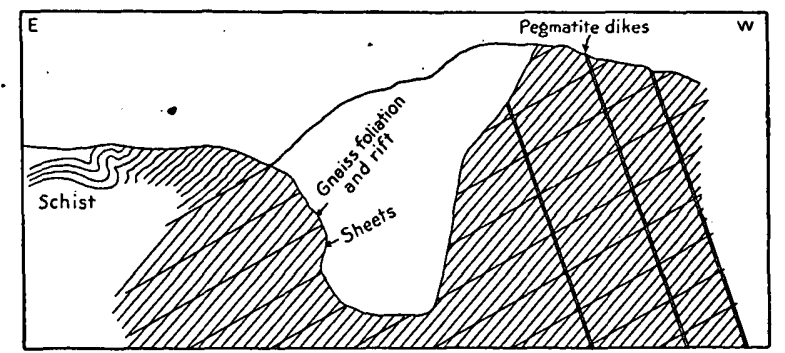

Figure 5.-Section of Holbrook quarry in Seymour. Sheet structure less regular than drawn.

crushed stone of grades 1 and 2 is used for road and concrete foundations, of grade 3 for sidewalks and flooring; that of a fourth grade, the sand sifted out of grade 3, is used for superior walks.

\section{NEW LONDON COUNTY.}

GROTON.

SALTER QUARRY.

The Salter quarry is in Groton Township, on the Thames River, three-fifths mile south-southeast of the Groton ferry landing. (See Pl. I.) Operator: John Salter \& Son, Groton, Conn.

The granite (specimen D, XXX, $4, a$, "Westerly granite" of Rice and Gregory's Manual of Geology of Connecticut), Groton granite, is a quartz monozonite of medium, slightly greenish gray color, and of even-grained fine granite texture, with feldspars and slender micas to 0.15 inch, but mostly not over 0.1 inch. Its constituents, 
in descending order of abundance, are light-gray soda-lime feldspar (oligoclase) mostly kaolinized and micasized and with calcite; light smoky quartz with hair-like crystals of rutile; medium slightly greenish gray potash feldspar (microcline slightly kaolinized with orthoclase) ; biotite (black mica) some of it chloritized, and a little muscovite or bleached biotite. Accessory minerals: Magnetite, apatite, allanite. Secondary minerals: A white mica, kaolin, calcite, limonite, chlorite.

An estimate of the mineral percentages by the Rosiwal method, applied to a camera-lucida enlargement (25 diameters) of a thin section, yields these results with a mesh of 0.7 inch and total linear length of 43.4 inches:

Estimated mineral percentages in Groton quartz monzonite.

$\begin{array}{lr}\text { Soda-lime feldspar (oligoclase) } & 41.25 \\ \text { Quartz } & \\ \text { Potash feldspar (microcline and orthoclase) } & \\ \text { Black mica (biotite) } & \\ \text { Magnetite - } & \\ & \end{array}$

The average diameter of the particles calculated from the same measurements is 0.0235 inch.

The stone effervesces with cold dilute muriatic acid. R. C. Wells, a chemist of the United States Geological Survey, finds that it contains 0.18 per cent of $\mathrm{CaO}$ (lime) soluble in warm dilute (10 per cent) acetic acid, which indicates a content of 0.32 per cent of $\mathrm{CaCO}_{3}$ (lime carbonate, calcite).

This is a monumental granite closely related to the blue Westerly, R. I., granites, but of about half as fine a texture. (See p. 95.) The floral carving reproduced in Plate VII, $B$ (p. 128), shows its adaptation to sculpture. As in quartz monzonites generally the contrast between its polished and cut face is marked. Minute particles of magnetite and pyrite appear on the polished face.

The quarry, opened about 1835, measures about 550 feet in a northeast direction by 50 to 100 feet across and from 20 to 30 feet in depth. The stripping consists of 5 to 15 feet of clay and sand. The working face is on the east, and the west side is being filled with grout as the face recedes.

Rock structure: The granite forms an apparent dike, 12 feet thick, dipping about $20^{\circ} \mathrm{E}$. between two masses of gray and black diorite gneiss (specimen D, XXX, 4, b, "New London granite gneiss," No. 35, of the State preliminary geologic map), with a foliation striking N. $65^{\circ} \mathrm{W}$., and dipping $75^{\circ} \mathrm{N}$. $25^{\circ} \mathrm{E}$., which is injected with pegmatite. This gneiss .consists of quartz, oligoclase, microcline, and hornblende, named in the usual order. The granite 
sheets are short lenticular, 2 to 12 feet thick, dipping $20^{\circ} \mathrm{SW}$. The sheets in the gneiss capping, which is 10 to 20 feet thick, are 6 inches to 5 feet thick and dip $15^{\circ} \mathrm{S}$. There are no joints. The rift is reported as dipping about $10^{\circ} \mathrm{NE}$., and the grain as vertical with N. $70^{\circ}$ E. course. Niles in 1876 reported evidences of compressive strain at this quarry. ${ }^{1}$

The plant comprises two derricks, a hoisting engine, and two steam drills.

Transportation is by cartage to wharf or rail at Groton.

The product is mostly monumental stone and some for trimmings. Its market is general. The gneiss is sold for breakwater use. Specimens: Monument to Col. William Ledyard (killed in battle of Groton Heights, 1781) in Ledyard Cemetery, Groton; monument to first four founders of Stonington at Wequetequock burying ground, Stonington; Edward Newman obelisk, Woodlawn Cemetery, New York; Rev. Byron A. Woods sarcophagus, Forest Hill Cemetery, Philadelphia; Charles Tyler statue, Druid Hill Ridge Cemetery, Baltimore; and the Kennard Celtic cross, Kensico Cemetery, Valhalla, N. Y., shown in Plate VII, $B$.

M'INTOSH QUARRY.

The McIntosh quarry is in Groton Township, on Broad Street extension, a mile northeast of Groton village, on the E. W. Crouch farm. (See Pl. I.) Operator, D. McIntosh, 64 Belden Street, New London, Conn.

The granite (specimen D, XXX, 2, a, "Mamacoke gneiss," No. 36, of the State preliminary geologic map) is a biotite granite gneiss of general medium pinkish gray color and of gneissose banded texture with pinkish and grayish bands from 0.5 to 0.3 inch wide. Its particles are fine, with feldspars to 0.2 inch. Its constituents, in descending order of abundance, are light pink potash feldspar (microcline somewhat kaolinized) intergrown with quartz more or less circular in cross section; light smoky quartz; milk-white soda-lime feldspar (oligoclase to oligoclase-andeșine) mostly much kaolinized and micasized and with calcite; biotite (black mica) much chloritized and a little muscovite or bleached biotite. Accessory minerals: Magnetite, pyrite, garnets, tourmaline, zircon. Secondary minerals: A white mica, kaolin, chlorite, calcite. A band of quartz and microcline is 1.12 millimeters wide. The stone effervesces with muriaticacid test.

This is an attractive stone, both on account of its delicate color and banded texture.

The quarry is a small opening without plant.

\footnotetext{
${ }^{1}$ Niles, W. H., The geological agency of lateral pressure exhibited by certain movements of rocks: Boston Soc. Nat, Hist; Proc, vol. 18 (1875-6), p. 279,
} 
Rock structure: The gneiss foliation is vertical with about east to west course. The rift is transverse to the foliation. Both rift and grain fractures are smoother than those along the foliation.

Transportation is by cartage to Groton.

The product has been used for coping on a sea wall on the Plant estate at Eastern Point, $2 \frac{1}{2}$ miles south of Groton.

ECKERLEIN QUARRY.

The Eckerlein quarry is in the township of Groton, about onehalf mile east-southeast of Center Groton, near the top of a north to south ridge. (See Pl. I.) Operator, Robert Eckerlein, R. F. D., Groton, Conn.

The granite (specimen $\mathrm{D}, \mathrm{XXX}, 13, a$, related to "Westerly granite"), Center Groton granite, is a quartz monozonite of medium inclining to dark greenish gray color and of even-grained fine granitic texture, with feldspars.and slender micas to 0.1 inch. Its constituents, in descending order of abundance, are greenish-gray sodalime feldspar (oligoclase) micasized and kaolinized and with calcite; light smoky quartz, with hairlike crystals of rutile and cavities in sheets, with cracks parallel thereto; slightly buff gray potash feldspar (microcline and orthoclase), some of the microcline kaolinized and micasized in center and also intergrown with quartz more or less circular in cross section; biotite (black mica), mostly chloritized and with needles, probably of rutile; and some muscovite or bleached biotite. Accessory minerals: Magnetite, apatite, allanite, rutile. Secondary minerals: Kaolin, white micas, calcite.

Some of the granite (specimen D, XXX, 13, $b$ ) is of medium gray shade and warm tint. Its texture and constituents are like those of the other. The potash feldspar is, however, faintly pinkish, and the soda-lime feldspar (oligoclase to oligoclase-andesine) is milk white. Zircon is accessory. Both rocks effervesce with the muriaticacid test.

An estimate of the mineral percentages made by applying the Rosiwal method to a camera-lucida enlargement (25 diameters) of a thin section yields these results with a mesh of 0.8 inch and a total linear length of 45.7 inches:

Estimated mineral percentages in Center Groton quartz monzonite.

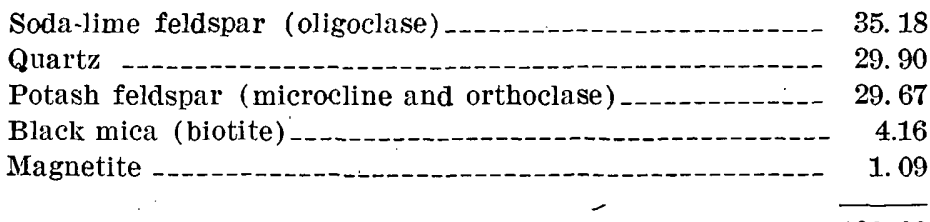

100.00

The average diameter of the particles calculated from the same measurements is 0.0256 inch. 
These are fine-grained monumental granites, about half as fine as . "Blue Westerly" and of different color."

Like other quartz monzonites, these cut and hammer light, the cut or hammered face affording not a little contrast of shade to the polished face, which is darker than the rough face.

The quarry, opened in 1855 , measures about 150 feet by 1.00 feet and from 25 to 40 feet in depth. The stripping consists of 5 to 14 feet of sand and bowlders.

Rock structure: The darker granite (specimen 13,a) is 10 feet thick and overlies the lighter (specimen 13, b). The sheets, 22 inches to 13 feet thick, dip gently east and south. There are two sets of joints, set A striking N. $15^{\circ} \mathrm{W}$., dipping $65^{\circ} \mathrm{E}$., spaced 5 to 50 feet; set $\mathrm{B}$, striking $\mathrm{N}$. $80^{\circ} \mathrm{E}$., vertical, one only in center. The rift is reported as having a north to south course and steep eastward dip, and the grain as east to west, with steep southward dip. Both are equally marked. A 4-foot pegmatite dike, with feldspars up to 12 inches and muscovite to 6 inches, strikes N. $10^{\circ} \mathrm{W}$. and dips $50^{\circ} \mathrm{W}$. The granite is slightly discolored on either side of this dike. Rusty stain is 2 to 4 inches thick on sheet surfaces.

The plant comprises a hoisting engine, two steam derricks and siphon pipe.

Transportation is by cart $4 \frac{1}{2}$ miles to Groton.

The product is used for monuments. Specimens: Beckwith and Rogers monuments, Cedar Grove Cemetery, New London.

$$
\text { KOPP QUARRY. }
$$

The Kopp quarry is in Groton Township, about one-half mile southeast of Center Groton and one-fourth mile S. $30^{\circ} \mathrm{W}$. of the Eckerlein quarry. Operator: Jacob K. Kopp, 2 Bishop Street, New London, Conn.

The granite (specimen D, XXX, 12, a, related to "Westerly granite") is a quartz monzonite of medium faintly greenish gray color and of even-grained fine to very fine granitic texture, with feldspars and mica to 0.05 inch.

This is a monumental granite of finer texture than that of the Eckerlein quarry, more nearly like that of "Blue Westerly," "and of shade intermediate between specimens $a$ and $b$ of the Eckerlein quarry.

The quarry opened in 1890 is undeveloped.

The stone has been used for monuments, and cuts light.

${ }^{1}$ Compare descriptions of "Westerly Blue" granites in Bull. U. S. Geol. Survey No. 354,1908 , pp. 192,195 , 205; also description of other fine Connecticut granttes on pp. 124 and 125 of this bulletin.

$97730^{\circ}-$ Bull. $484-11-7$ 
M'GAUGHEY QUARRY.

The McGaughey quarry is in Groton Township, in the village of Mystic, one-half mile northwest of Mystic station. Operator: William R. McGaughey, Mystic, Conn.

The granite (specimens D, XXX, 20, $a, b$, related to "Westerly granite") is a quartz monzonite of medium inclining to dark faintly greenish gray color, and of even-grained fine granitic texture, with feldspars and mica under 0.2 inch. Its constituents, in descending order of abundance, are grayish translucent soda-lime feldspar (oligoclase-andesine) partly kaolinized and micasized; medium. smoky quartz with hairlike crystals of rutile and cavities in sheets; clear, colorless to faintly pinkish potash feldspar (microcline and orthoclase) intergrown with quartz more or less circular in cross section; biotite (black mica), some of it chloritized, and a little muscovite or bleached biotite. Accessory minerals: Magnetite, pyrite, apatite, allanite, zircon, and purple fluorite. Secondary minerals: Kaolin, a white mica, calcite, chlorite. It effervesces with muriatic-acid test.

This is a monumental granite, almost as fine as "Blue Westerly" but with more abundant black mica and thus of darker. shade. It cuts light gray and polishes dark gray. The polish is fair, but shows pyrite and magnetite. The stone is reported as "very hard."

The quarry, opened before 1827, measures about 100 feet from: east to west by 35 feet across with a 50-foot working face (cliff) on the south.

Rock structure. The granite forms an apparent dike, 25 feet thick, underlain by a coarse biotite granite gneiss (specimen D, XXX, 20, $d$, "Mamacoke gneiss," No. 26, of the State preliminary geologic map) and dipping gently south into the base of the cliff, and also overlain near its top by a similar gneiss. The sheets, 6 inches to 5 feet thick, but mostly under 13 inches, are about horizontal. The foliation of the gneiss dips steep north or vertical. The only set of joints strikes N. $40^{\circ}$ E., dips $65^{\circ}$ S. $50^{\circ}$ E., forms a 10 -foot heading in middle, and is spaced 5 to 30 feet. A vertical " blind seam," striking N. $60^{\circ} \mathrm{E}$., proves to be a veinlet, a millimeter wide, of a fibrous light-brownish zeolite ('natrolite?) with a more minute parallel branch, one-half millimeter away, of another zeolite near stilbite. This mineral has replaced some of the adjoining oligoclase-andesine and also sends microscopic veinlets across quartz particles. The granite is discolored for one-half inch on either side of the veinlet. A vertical pegmatite dike strikes N. $30^{\circ} \mathrm{W}$. There are also dikes of pegmatite and aplite in the gneiss. An inclusion of the gneiss, 4 by $2 \frac{1}{2}$ feet, lies in about center of granite mass.

The plant consists of two hand derricks.

Transportation is by cartage to New York, New Haven \& Hartford Railroad. 
The product is used for monuments. Specimen: McGaughey monument, Elmgrove Cemetery, Mystic.

\section{EAS'T LYME.}

MALNATI PINK QUARRY.

The Malnati Pink quarry is in the township of East Lyme, 2 miles northwest of the Niantic station and 160 feet above it. (See Pl. I.) Operator: Angelo Malnati, 76 Liberty Street, Quincy, Mass.

The granite (specimen D, XXX, 7, a, rough; $e$, polished and ham: mered, related to "Westerly granite "), "Golden pink Niantic," is a quartz monzonite of medium pinkish-gray color and of evengrained fine granitic texture, with feldspars and mica to 0.1 inch. Its constituents, named in descending order of abundance, are light smoky quartz, with hair-like crystals of rutile and with few cavities; quite pinkish translucent to milk-white soda-lime feldspar (oligoclase), considerably kaolinized, micasized, and with calcite; clear, colorless to translucent white potash feldspar (microcline and a little orthoclase); biotite (black mica), some of it chloritized and a little muscovite or bleached biotite. Both feldspars are intergrown with quartz more or less circular in cross section. Accessory minerals: Magnetite, apatite. Secondary minerals: Hematite from magnetite, kaolin, a white mica, calcite.

A somewhat darker granite (specimen $\mathrm{D}, \mathrm{XXX}, 7, b$ ), "Golden pink dark," from the same quarry, is of medium inclining to dark pinkish gray color and of the same texture and composition as the other, but the quartz is more smoky (section shows cavities in sheets), the oligoclase is more altered and darker, and zircon appears.' Both granites effervesce with cold dilute muriatic acid.

An estimate of the mineral percentages by the Rosiwal method, applied to a camera-lucida enlargement ( 25 diameters) of a thin section, yields these results with a mesh of 1.5 inches and total linear length of 27 inches:

Estimated mineral percentages in Niantic quartz monzonite.

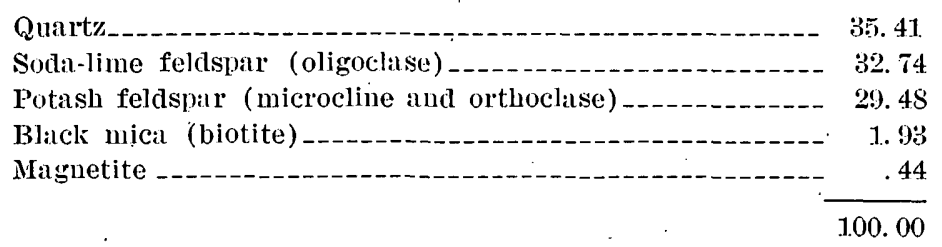

The average diameter of the particles, calculated from the same measurements, is 0.0275 inch.

These granites are reddish monumental granites of about half the grade of fineness of "Blue Westerly." Owing to streaks which are 
said to appear on large polished faces, the stone is used chiefly for rough and hammered or carved work, but is admirably adapted for inscriptions, the light pinkish gray hammered face contrasting strongly with the reddish-brown polished face (specimen $7, e$ ).

The quarry, opened in 1900 , measures about 250 feet from east to west by 65 feet across and 75 feet in depth.

Rock structure: The granite occurs in a dike-like mass, 40 feet thick, dipping about $20^{\circ}$, between a lower and an upper mass of gneiss, which has a foliation striking N. $30^{\circ}$ E., and dipping $50^{\circ}$ S. $60^{\circ}$ E. This ("Mamacoke granite gneiss," No. 36, of the State preliminary geologic map) is a biotite granite gneiss of medium slightly pinkish gray color and of medium gneissose texture. Its quartz is light smoky with cavities in sheets; its feldspars are lightpink microcline and orthoclase and milk-white oligoclase. The overlying mass is 20 feet thick and is more altered and weathered, its feldspars having largely passed into crystalline kaolin, making the rock very friable. The granite sheets, 3 to 10 feet thick, are short, irregular lenses. There are two sets of joints: Set A, striking $N$. $5^{\circ}-10^{\circ} \mathrm{W}$., vertical, is spaced 3 to 15 feet; set $B$, striking east-west, vertical, is spaced 3 to 15 feet. The rift is reported as north-south and the grain as east-west, both vertical and of like fissility. Rusty stain is 2 to 4 inches thick on sheet surfaces.

The plant comprises two derricks, a hoisting engine, a steam drill, a vertical polisher and engine for same, and two steam pumps.

Transportation is by cart over 2 miles to Niantic.

The product is used for monuments, which are finished at Quincy, Mass.

CARLSON QUARRY.

The Carlson quarry is in the township of East Lyme, about 2 miles northwest of Niantic station, and about 600 feet southwest of the Malnati quarry. (See Pl. I.) Operator: The Golden Pink Quarry Co., Peter M. Carlson, proprietor, Niantic, Conn.

The granite, "Golden pink," is a quartz monzonite of medium pinkish gray color and of even-grained very fine granitic texture, identical in composition and qualities with that of the Malnati quarry, described on page 97.

The quarry, opened in 1900 , measures about 125 by 75 feet, and from 10 to 30 feet in depth.

Rock structure: The granite occurs in a dikelike mass, 40 feet thick, dipping about $30^{\circ}$ south between masses of biotite granite gneiss identical with that at the Malnati quarry. The foliation of the overlying gneiss, which is 20 feet thick, strikes $\mathrm{N}$. $80^{\circ} \mathrm{W}$. and dips $25^{\circ}-30^{\circ} \mathrm{N} .10^{\circ} \mathrm{E}$. The granite sheets, up to 10 feet thick, are short shelly lenses with irregular dip. There are two sets of joints: Set A, striking N. $40^{\circ}-55^{\circ}$ E., curving certically, is spaced 5 to 12 feet; set 
$\mathrm{B}$, striking about north, vertical, forms a heading at east side and one or two at west side. One pegmatite dike only.

The plant comprises one hand and one steam derrick and engine, and a steam pump.

Transportation is by cart 2 miles to Niantic.

The product is used for monuments.

$$
\begin{array}{cc}
\because ! & \text { LYME. } \\
\because \because \quad \text { JOSHUA ROCK QUARR }
\end{array}
$$

The Joshua Rock quarry is in Lyme Township at Joshua Rock on the east shore of Connecticut River, 2 miles north of Essex Wharf. (See Pl. I, p. 8.) Operator: Joshua Rock Granite Co., care of C. E. Pratt, Essex, Conn.

The granite (specimens D, XXX, 17, a, b, "Lyme granite gneiss," No. 34, of the State preliminary geologic map), variegated granite, is an agirite granite gneiss of general medium inclining to dark slightly purplish gray color with fine reddish, pinkish, greenish, and black bands also cherry-reddish spots. Its texture is fine gneissose, banded with feldspar and black silicate under 0.2 inch. Its constituents, named in.descending order of abundance, are clear, colorless to dense pinkish potash feldspar (microcline) more or less kaolinized and coarsely. intergrown with quartz; light smoky quartz with cavities in sheets and cracks parallel thereto; milk-white soda-lime feldspar (oligoclase-albite) more or less kaolinized; and black æegirite (green in thin section). Accessory minerals: Magnetite (or ilmenite), titanite, yellow colophonite (lime-iron garnet), these three in some abundance, and zircon, allanite. Secondary minerals: Hematite and limonite stain, calcite, kaolin. There is no effervescence with muriatic acid test. The banding is due to the varying abundance or absence of ægirite, or the preponderance of quartz or feldspar in parallel planes. The quartz and feldspar are stained cherry red from hematite either evenly in bands or else in irregularly disseminated spots.

The quarry is on the west side of a cliff over 60 feet high, which is the working face.

Rock structure: The gneiss foliation strikes N. $75^{\circ}-80^{\circ} \mathrm{W}$. and dips $45^{\circ} \mathrm{N} .10^{\circ}-15^{\circ} \mathrm{E}$. There are passages of biotite and other black silicates (dikes or knots?) 1 to 3 feet thick (specimen D, XXX, 17, c). Vertical joints strike north.

The quarry has not been in operation for several years.

SELDEN NECK QUARRIES.

The Selden Neck quarries are in Lyme Township, on Selden Neck, on the east shore of Connecticut-River, opposite Deep River station (See Pl. I.) Owner, A. W. Parker Co., 361 Fulton Street, New York. 
The granite (specimens D, XXX, 15, $a, b$, "Mamacoke gneiss," No. 36, of the State preliminary geologic map) is a hornblendebiotite granite gneiss of medium inelining to dark reddish gray color streaked with black, and of fine gneissose texture with lenses and laminæ of black silicates 0.1 to 0.2 inch apart, and with feldspar particles under 0.1 inch. Its constituents, named in descending order of abundance, are reddish gray potash feldspar (orthoclase and less microcline); light smoky quartz, with cavities in sheets; a little reddish gray soda-lime feldspar (oligoclase); greenish hornblende; biotite (black mica). Accessory minerals: Apatité; zircon. Secondary minerals: Hematite, limonite, kaolin, calcite. Both feldspars are somewhat kaolinized. The stone effervesces slightly with muriatic-acid test.

- This is a fine-grained reddish constructional granite with conspicuous bright black streaks and lenses, but without other mineral contrasts.

There are two quarries: A southern one, east-southeast of Deep River station, and a northern one due east of it. The former measures about 250 by 40 feet, with a working face on the east. The other, about one-fourth mile west-northwest of it, measures about 200 feet from east to west, with a working face on the north 60 feet high.

Rock structure: At the south quarry the gneiss foliation strikes N. $80^{\circ}-85^{\circ}$ E. and dips $20^{\circ}-25^{\circ}$ N. $5^{\circ}-10^{\circ}$ W. The sheets, 1 to 3 feet thick, dip with the foliation. There are four sets of joints: Set A, striking N. $70^{\circ}$ E., dipping $75^{\circ}$ S. $20^{\circ}$ E. is spaced 2 to 5 feet; set B, striking north, vertical, is spaced 2 to 5 feet; set C, striking N. $40^{\circ} \mathrm{E}$., is vertical; set $\mathrm{D}$, striking N. $75^{\circ}-80^{\circ} \mathrm{W}$., dips $30^{\circ} \mathrm{S}$. $10^{\circ}-15^{\circ} \mathrm{W}$. At the northern opening the gneiss foliation strikes $\mathrm{N}$. $75^{\circ} \mathrm{E}$. and dips $25^{\circ} \mathrm{N}$. $15^{\circ} \mathrm{W}$. The sheets, 2 to 6 feet thick, dip with the foliation. There are two sets of joints: Set A, striking N. $50^{\circ} \mathrm{E}$., vertical; set $\mathrm{B}$, striking $\mathrm{N} .10^{\circ} \mathrm{E}$, , vertical or steep east, forming an 8-foot wide heading at east edge of quarry. Pegmatite dikes, 1 inch to 2 feet thick, dip low northeast. The rift at both quarries is parallel to the long axes of the lenses and at right angles to the gneiss foliation. The grain is parallel to that foliation and the hardway is transverse to it and to the lenses.

These quarries were not in operation in 1908 and had evidently been idle for a number of years. Transportation was by cart or car one-fourth mile to dock.

OLD LYME.

MACCURDY QUARRY.

The MacCurdy quarry is in the township. of Old Lyme, on Duck River, between Lyme village and the Lyme \& Blackhall station. 
(See Pl. I.) Owner, Mrs. Evelyn MacCurdy Salisbury, 237 Church Street, New Haven, Conn.

The granite (specimens $\mathrm{D}, \mathrm{XXX}, 49, b, c, d$, the last being a polished cube with edges 3.5 inches), MacCurdy granite, is a pegmatite with the composition of a biotite granite. Its general color is medium pinkish-reddish gray spotted with black. Its texture is very coarse porphyritic with feldspars to 1.5 inches (exceptionally to 4.5 inches) and mica mostly under 0.5 inch (exceptionally to 1 inch). Its constituents, named in descending order of abundance, are pinkishreddish potash feldspar (orthoclase and microcline, both minutely intergrown with oligoclase) somewhat micasized; light to medium smoky quartz with cavities in parallel or intersecting sheets; light pinkish to cream-colored and milk-white, rarely clear, striated sodalime feldspar (oligoclase), generally micasized; and biotite (black mica), some of. it chloritized. Accessory minerals: Magnetite, pyrite, apatite quite a little, and zircon. Secondary minerals: White micas, calcite, hematite, chlorite. ${ }^{1}$

The stone effervesces with cold dilute muriatic acid. R. C. Wells, a chemist of the United States Geological Survey, finds that it contains 0.46 per cent of $\mathrm{CaO}$ (lime) soluble in warm dilute of 10 per cent acetic acid, which indicates a content of 0.82 per cent of $\mathrm{CaCO}$ (lime carbonate, calcite), the presence of which mineral is also shown by the microscope.

W. P. Blake, in 1880, determined the specific gravity of the reddish feldspar as 2,580 and that of the granite as 2,643, and the weight of a cubic font of it as 165.2 pounds, or 12.106 cubic feet to 2,000 pounds.

The contrasts between its minerals, the cleavage planes of the large porphyritic feldspars reflecting the light, the iridescence of some of the feldspars and the attractiveness of its general color make this an unusual rock. The polished face brings out the colors still more strongly. It is well adapted in the rough for monumental use, and, when polished, for internal decorations. Between 1871 and 1881 this pegmatite was brought to the attention of and examined more or less thoroughly by James D. Dana, A. Daubrée, Des Cloiseaux, G. W. Hawes, W. P. Blake, and C. U. Shepard, and specimens of it were exhibited at the expositions of Philadelphia, 1876, and Paris, 1878. Prof. Newberry referred to it in his Tenth Census Report on building stones. $^{2}$

The quarry, not worked for a number of years, measures about 50 by 30 feet and from 5 to 10 feet in depth from the present ledge surface.

1 This granite was first examined microscopically by Des Cloiseaux, who regarded the fcldspar intergrown with the microcline as albite. See Am. Jour. Sci., 3d ser., vol. 20, 3880 , p. 385.

2 Vol. 10,1884, p. 321 . 
Rock structure: Several dikes of the pegmatite, 15 to 22 feet thick, have penetrated a mass of banded gneiss parallel to its foliation, which strikes N. $50^{\circ}-60^{\circ}$ E. and dips $40^{\circ}$ to $45^{\circ}$ N., $30^{\circ} \mathrm{E}$. At one point the pegmatite apparently crosses the foliation of the gneiss horizontally. The gneiss (specimen $\mathrm{D}, \mathrm{XXX}, 49, a$, "Lyme granite gneiss," No. 34, of the State preliminary geologic map) is a biotitic quartz monzonite gneiss of medium inclining to dark gray color with fine bands of various grays and of fine gneissose texture, with particles under 0.2 inch and bands from 0.1 to 0.3 inch. The constituents of the bands crossed by one thin section are, in the usual order, quartz with cavities in many parallel sheets, with rift cracks parallel thereto, some of them filled with fibrous muscovite, also with a set of sparser and finer cracks at right angles to the first set (the rift coincides with the foliation of the rock); oligoclase, orthoclase, and biotite.

Transportation is by cart about one-half mile to New York, New Haven \& Hartford Railroad.

Product: The Channing Memorial Church, with its steeple, at Newport, R. I., was built of this stone in 1881. The trimmings, however, were of light and dark gray granite.

\section{STONINGTON.}

MASONS ISLAND QUARRY.

The Masons Island quarry is in the township of Stonington, at the northwest end of Masons Island, on Pine Hill. (See Pl. I.) Operator: E. S. Belden \& Sons, Hartford, Conn.

The granite (specimens D, XXX, 21, a, "Mamacoke gneiss," No. 36 , of the State preliminary geologic map) is a quartz monzonite flow gneiss of banded light and dark gray shade. Its texture is even grained; fine banded, with feldspars under 0.2 inch and mica under 0.1 inch. Its constituents, ncmed in descending order of abundance, are pale smoky quartz, with cavities in sheets, milk-white sodalime feldspar (oligoclase, probably), some of it nicasized; clear, colorless potash feldspar (microcline, probably a little orthoclase also) ; biotite (black mica). Accessory minerals: Magnetite, garnet, allanite, zircon.

The quarry, opened in 1880, measures about 200 feet from east to west, with a working face 30 to 60 feet high on the north. The stripping consists of 7 feet of gravel.

Rock structure: The rock appears to be a granite with flowage bands caused by the different distribution of the biotite in parallel bands. The banding dips low west. There are lenses of coarse pegmatite (white and pink feldspar and biotite) parallel to the bands. There are also dikes of this pegmatite, some vertical, some dipping 
southeast, others northwest. ${ }^{1}$ The sheets, 6 inches to 4 feet thick, are horizontal. One joint only, strike about east-west.

The plant comprises three derricks, three hoisting engines, a cable engine, and three large rock drills.

Transportation is by a 450-foot track to dock on Mystic Harbor.

The product is used entirely for riprap for breakwater construction (Port Jefferson breakwater and others).

NEW ANGUHLAA QUARRY.

The New Anguilla quarry is in the township of Stonington, a mile east of Anguilla Creek, and $1 \frac{1}{2}$ miles west-northwest of the Westerly, R. I., station. (See Pl. I.) Operator: Morrison Granite Co., 48 Morgan Street, Westerly, R. I.

The granite (specimen D, XXX, 19, b), "New Anguilla," is a quartz monzonite of medium slightly bluish gray shade and of evengrained fine granitic texture with feldspars under 0.1 inch and mica under 0.05 inch. Its constituents, named in descending order of abundance, are light, smoky quartz with cavities; milk-white sodalime feldspar (oligoclase) much kaolinized, micasized and with calcite; in about equal amount slightly bluish gray potash feldspar (microcline and orthoclase) intergrown with quartz more or less circular in cross section; biotite (black mica), some of it chloritized, and a little muscovite or bleached biotite. Accessory minerals: Titanite, apatite, magnetite, purite, zircon. Secondary minerals: Kaolin, a white mica, calcite. The stone effervesces with cold dilute muriatic acid.

This is a monumental granite resembling "Blue Westerly" in color and texture." Like other quartz monzonites, it cuts and hammers light.

The stone from another opening (specimen $\mathrm{D}, \mathrm{XXX}, 19, c$ ) is of light buff inclining to medium gray color and of even-grained, medium texture, with feldspars to 0.25 inch and mica under 0.1 inch. It consists of cream-colored feldspar, medium smoky quartz, and black mica. It effervesces with muriatic-acid test. This is hardly suitable for monumental use.

The quarry, but recently opened, measures about 100 feet from east to west by 30 feet across and averages 4 feet in depth. Another opening 500 feet south is 40 feet by 20 and 5 to 8 feet deep.

Rock structure: The bluish-gray quartz monzonite has a capping of gneiss 3 to 5 feet thick. This (specimen D, XXX, 19, a), probably "Putnam gneiss" of Rice and Gregory," is a biotite granite

1 J. F. Kemp described this pegmatite in his Granites of southern Rhode Island and Connecticut: Bull. Geol. Soc. America, vol. 10, 1899, pp. 373, 374.

2 See Bull. U. S. Geol. Survey No. 354, p. 195.

${ }^{3}$ Nanual of the geology of Connecticut: Bull. Connecticut Geol. and Nat. Hist. Survey No. 6,1906, p. 132 . 
gneiss of medium gray shade, finely banded with dark gray, and of fine to very fine unplicated gneissose texture with feldspars under 0.1 inch and mica under 0.05 inch. Its constituents, named in the usual order, are microcline, quartz, oligoclase, biotite with accessory magnetite, apatite, zircon, allanite. The foliation strikes nearly east to west and dips $5^{\circ} \mathrm{N}$. to vertical. The contact between granite and gneiss is in places very jagged or bordered with 12 inches of pegmatite and aplite, which also penetrate the gneiss. The granite sheets, 6 inches to 5 feet thick, are not yet fully exposed. There are three sets of joints: Set A, striking from east to west, vertical; B, striking north to south, vertical and discontinuous; set C (one only), striking N. $60^{\circ} \mathrm{W}$., dipping $55^{\circ} \mathrm{S} .30^{\circ} \mathrm{W}$. The rift is reported as horizontal and the grain and hardway as equally fissile. The flow structure dips $25^{\circ} \mathrm{S}$. At the south opening a dike or band of the quartz monzonite, 10 feet wide, has the medium-grained granite, described on page 103 ; on both sides of it. Flow structure dips $50^{\circ}-70^{\circ} \mathrm{S}$.

Transportation involves cartage of about 2 miles to Westerly, R. I.

The blue-gray quartz monzonite will be used for monuments.

MURRAY QUARRY.

The Murray quarry is in the village of Pawcatuck, in the township of Stonington, about three-fourths mile northwest of Westerly station. (See Pl. I.) Operator, A. Murray \& Co., Westerly, R. I. The granite (specimen D, XXX, 18, a, "Sterling granite," No. 24, of the State preliminary geologic map), "Red Westerly," is a biotite granite of dark inclining to medium reddish gray color and of even-grained granitic medium inclining to coarse texture, with feldspars to 0.4 inch (exceptionally 0.5 inch) and mica to $0.2 \mathrm{inch}$, but mostly under 0.1 inch. Its constituents, named in descending order of abundance, are reddish potash feldspar (microcline and orthoclase) slightly kaolinized; amethystine smoky quartz with cavities in sheets; cream-colored striated soda-lime feldspar (oligoclase to oligoclase-albite) much kaolinized and micasized, in places stained red from hematite; biotite (black mica) some of it chloritized, and a little muscovite or bleached biotite. Accessory minerals: Magnetite, pyrite; apatite, allanite, zircon. Secondary minerals: White micas, kaolin, chlorite, calcite, limonite from allanite, hematite from magnetite. There is marked effervescence with cold dilute muriatic acid.

This a brilliant constructional granite of attractive tint. Its mineral contrasts are confined to those between its black mica, pink and cream-colored feldspars. The stone is identical with that of the Redstone quarry at Westerly, R. I., which contains 35.40 per cent of potash feldspar, 29.87 per cent of quartz, 28.35 per cent of soda-lime feldspar, and 6.74 per cent of black mica. ${ }^{1}$ 
The acetic acid test of that granite shows 0.25 per cent of $\mathrm{CaO}$ (lime) or 0.446 per cent of $\mathrm{CaCO}_{3}$ (lime carbonate). This one contains fully as much, if not a little more, $\mathrm{CaCO}_{3}$.

Another biotite granite (specimen $\mathrm{D}, \mathrm{XXX}, 18, b$ ) from the same quarry is of dark inclining to medium slightly reddish gray. It is a little darker and less reddish than the above. Its texture is evengrained medium, with feldspar to 0.3 inch and mica to 0 . inch. Its constituents are like those of the other, but the soda-lime feldspar is of greenish-gray color. The effect of this and of the finer texture of the stone is to darken its general shade.

The quarries, opened about 1889 , are two, a northern one, measuring about 150 by 75 feet, with a 40 -foot working face on the west, and a southern one, separated from the other by a 50 -foot mass, and consisting of two 50-foot square openings, one east of the other.

Rock structure: The sheets, 2 to 10 feet thick, dip gently north and, at south end, west. Joint, flow, grain, and dike courses are shown in figure 6. Joint set A dips $65^{\circ} \mathrm{N}$ : $30^{\circ} \mathrm{W}$., is spaced 4 to 20 feet and over; set $\mathrm{B}$ is vertical, reddish, coated with epidote, forms east and west walls, is spaced 2 to 20 feet. Flow structure dips $60^{\circ}$ $\mathrm{N}$. The rift is reported as horizontal and grain vertical. The unquarried mass between the two quarries and about 10 feet of the south end of the northern quarry consist of the finer darker granite (specimen $b$ ), which constitutes a dike or band. Dikes of pegmatite (specimen $\mathrm{D}, \mathbf{X X X}$,

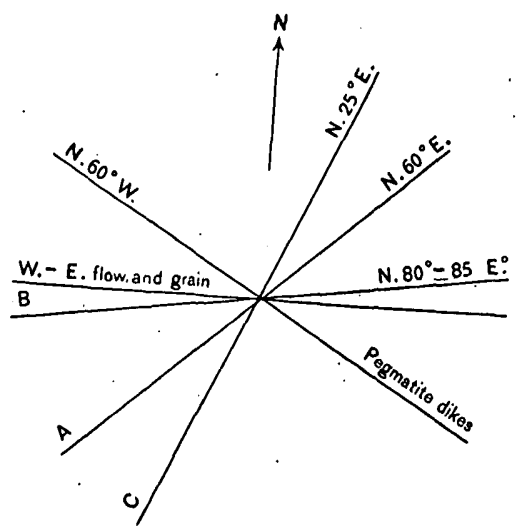

Ficine 6.-Structure at Murray quarry, Pawcatuck, Stonington.

18, $c$ of pink and cream-colored feldspars, smolky quartz, biotite, and allanite, with aplite), some of it very coarse, dip $50^{\circ}$. S. $30^{\circ}$ $\mathrm{W}$. and measure up to 6 inches thick. There is a milky quartz lens or dike a foot thick. A 5-inch geode, lined with crystals of pyrite, was found. Rusty stain in places to 9 inches thick averages about 2 inches on sheet surfaces.

The plant comprises two derricks, a hoisting engine, a steam rock drill, an air compressor (capacity, 75 cubic feet of air per minute), two air plug drills, and a steam pump.

Transportation is by cartage of a mile to railroad at Westerly, R. I.

The product of the main quarry (specimen $a$ ) is used for building and trimming. That of the smaller $(b)$ for monuments. Specimens: Trimmings on building at northwest corner of Broadway and Fourth 
Street, New York; trimmings on addition to Providence Hospital (1905-6) ; trimmings on State armory, Westerly, R. I.

WATERTORD.

SCOTT QUARRY.

The Scott quarry is in Waterford Township, 3 miles north of New London, on Bolles Hill, about half a mile south of Quaker Hill village. (See Pl. I, p. 8.) Operator: W. F. Scott, R. F. D., Waterford, Conn.

The granite (specimen D, $\mathrm{XXX}_{\mathbf{6}} 9, b$, "Mamacoke gneiss," No. 36, of the State preliminary geologic map) is an ægirite granite gneiss of medium pinkish-purrlish gray color and of very fine slightly gneissose, in places banded, texture, with feldspars under 0.1 inch (rarely to 0.15 inch) and black silicate under 0.05 inch. Its constituents, named in descending order of abundance, are grayish-pinkish potash feldspar (microcline and orthoclase) intergrown with sodalime feldspar (oligoclase-albite) and somewhat kaolinized; light smoky quartz with cavities in sheets; a little separate soda-lime feldspar of the same kind; black ægirite (green in thin section). Accessory minerals: Magnetite, titanite. Secondary minerals: Kaolin and hematite stain. No effervescence with muriatic-acid test.

A specimen (D, XXX, 9,a) of a part with alternating black, gray, and reddish plicated bands from 0.1 to 0.3 inch wide, shows the same minerals with zircon, but the soda-lime feldspar is albite or oligoclasealbite and all separate. Some of the bands are largely quartz, others largely feldspar, still others mainly ægirite.

The quarry, opened in 1898, measures 150 feet along the highway by 50 feet from it and averages 5 feet in depth, with a woring face 20 feet high at the back.

Rock structure: The sheets, 1 to 4 feet thick, are about horizontal. Two sets of joints occur at rare intervals: Set A, striking N. $10^{\circ} \mathrm{W}$., dips $60^{\circ} \mathrm{W}$; ; set $\mathrm{B}$, striking N. $65^{\circ} \mathrm{E}$., dips vertical. The gneiss foliation strikes N. $10^{\circ}$ W. and N. $20^{\circ}$ E. and dips eastward. At one point this is sharply plicated along the strike. The rift is reported as vertical east to west, and the grain as vertical north to south. Dikes or lenses of pegmatite and aplite, to 2 feet thick, run with the foliation.

The plant comprises a hand derrick.

The product is underpinning, curbing, trimmings, steps, and paving. The quarry is worked only occasionally.

RICHARDS QUARRY.

The Richards quarry is in Waterford Township, 3 miles north of New London, and about 700 feet west of the Scott quarry. Operator: N. A. Richards, R. F. D., Waterford, Conn. 
The granite is an ægirite granite gneiss identical with that of the Scott quarry, described on paige 106.

The quarry at the top of a knoll is small and has not been worked for two or three years.

Rock structure: The sheets, 1 to 4 feet thick, dip low east and northeast. There are few pegmatite dikes and some quartz veins.

The plant comprises two hand derricks.

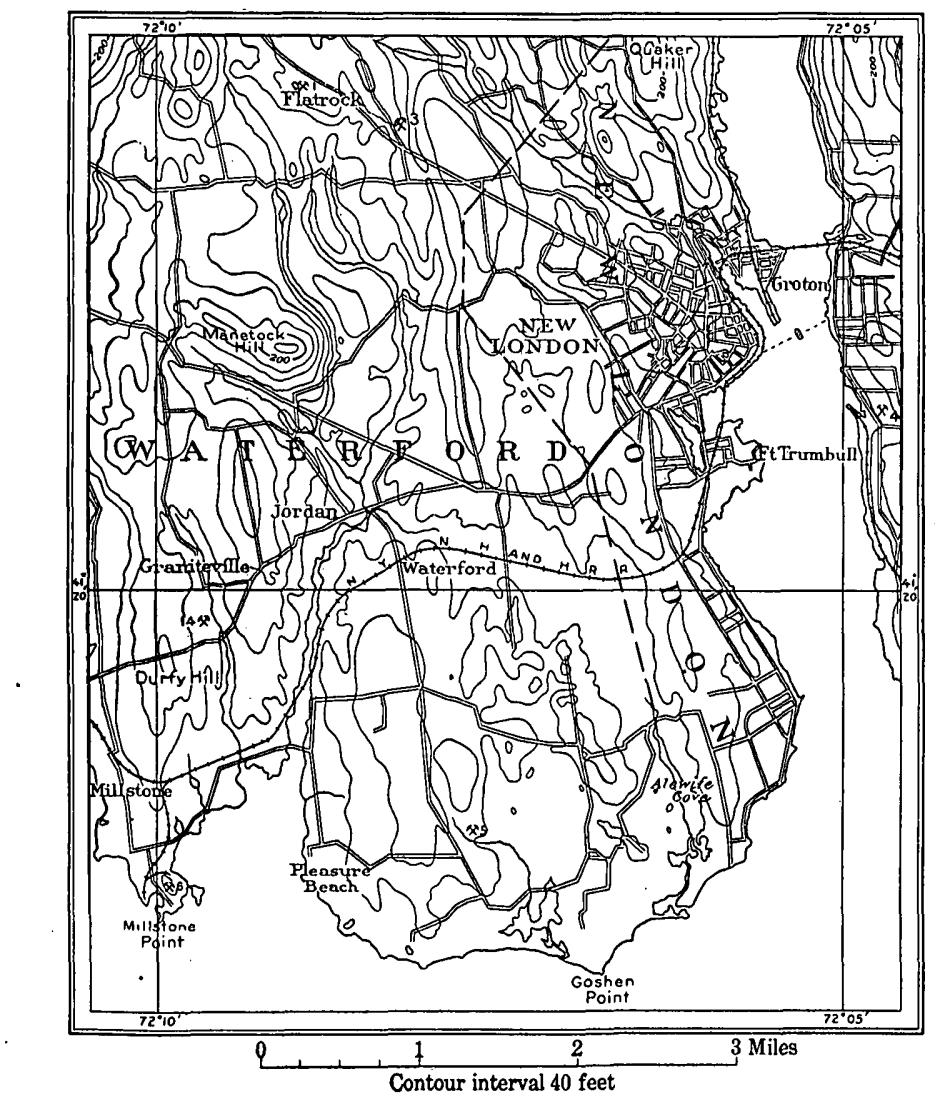

Figurw 7.-Map of granite quarries in south part of Waterford. 1, Flat Rock quarry ; $\mathbf{3}$, Goos; 5, Waterford; 6, Millstone; 14, Somers.

FLAT ROCK QUARRY.

The Flat Rock quarry is in Waterford Township, about 3 miles northwest of New London, on Flat Rock. (See Pl. I and fig. 7.) Operator: J. J. Ryan, 105 Blackhall Street, New London, Conn.

The granite (specimen D, XXX, 1, a, "Mamacoke gneiss," No. 36 , of the State preliminary geologic map) is an egirite granite gneiss of dark, inclining to medium, very faintly purplish gray color and of medium-grained gneissose texture, with feldspars to 0.3 inch 
and black silicate under 0.1 inch. Its constituents, in descending order of abundance, are medium smoky quartz, with cavities in sheets; milk-white potash feldspar (orthoclase and less microcline), coarsely intergrown with soda-lime feldspar (oligoclase); separate milk-white oligoclase; black ægirite (green in thin section). All the feldspars much kaolinized. Accessory minerals: Magnetite, titanite, zircon, apatite. Secondary minerals: Kaolin, hematite, and limonite stain from the magnetite and agirite. No effervescence with muriatic-acid test.

Specimen $\mathrm{D}, \mathrm{XXX}, 1, b$, from this quarry, is of medium inclining to dark pinkish gray, and of fine gnieissose texture, with feldspars to 0.2 inch (mostly under 0.1 inch), and black silicate to 0.2 inch. Its constituents are like those of $1, a$, but the second feldspar is oligoclase-andesine or oligoclase. The pinkish tinge is due to more abundant hematite from the magnetite particles.

These granites are devoid of contrasts and brilliancy. One is nearly smoke colored, the other pinkish.

The quarry is about 100 feet square by 10 to 20 feet deep.

Rock structure: The gneiss foliation strikes N. $50^{\circ}-55^{\circ} \mathrm{W}$. and dips $30^{\circ}$ S. $40^{\circ} \mathrm{W}$. Joints of set A strike N. $10^{\circ}$ E., dip $75^{\circ}$ E., and are spaced 10 to 30 feet. Those of set $\mathrm{B}$ striks $\dot{\mathrm{N}}$. $8^{\circ} \mathrm{W}$., dip $75^{\circ} \mathrm{S}$., and are spaced 10 to 30 feet. The rift is reported as horizontal.

The plant comprises a derrick and small hoisting engine.

Transportation is by cart 3 miles to New London.

The product is used for trimmings, curbing, and paving. Specimens: Trimmings on Harbor School and on First Congregational Church, Groton.

GOOS QUARRY.

The Goos quarry is in Waterford Township, $2 \frac{1}{2}$ miles northwest of New London. (See fig. 7.) Operator: Charles Goos, 46 Ashcraft Road, New London, Conn.

The granite (specimen D, XXX, 3, a, "Mamacoke gneiss," No. 36, of the State preliminary geologic map) is an ægirite granite gneiss of medium buff gray color, and of fine inclining to medium.gneissose texture, with feldspars and mica to 0.2 inch. Its constituents, named in descending order of abundance, are clear, colorless potash feldspar, microcline, and orthoclase, the former coarsely intergrown with soda-lime feldspar and slightly kaolinized; pale, smoky quartz with cavities in sheets; cream-colored soda-lime feldspar (pure albite); black ægirite (green in thin section). Accessory minerals: Magnetite (fifth in order of abundance), titanite, allanite, zircon. Secondary minerals: Kaolin, hematite; and limonite stain from magnetite and ægirite. No effervescence with muriatic-acid test. 
This is a dull grayish foliaceous stone, with fine dark particles and sparse cherry reddish stains.

The quarry, begun in 1897 , consists of two small openings.

Rock structure: A marked gneiss foliation strikes N. $80^{\circ} \mathrm{W}$. and $\operatorname{dips} 65^{\circ}$ N. $10^{\circ}$ E. Imperfectly developed sheets, $2 \frac{1}{2}$ to 4 feet thick, dip gently west. There are three sets of joints: Set A, striking north, vertical to steep east, are spaced 2 to 30 feet; set B, coinciding with the foliation, are spaced 12 to 15 feet; set C, striking N. $50^{\circ}$ E., occur at irregular intervals. The rift is reported as horizontal and the grain as parallel to the foliation.

The plant consists of a hand derrick.

Transportation is by cart $2 \frac{1}{2}$ miles to New London.

The product is used for coping, facing, and steps.

MILI.STONE QUARRY.

The Millstone quarry is in Waterford Township, on Millstone Point, 5 miles southwest of New London. (See Pl. I and fig. 7.) Operator, Henry Gardiner, Millstone, Conn.

The granite (specimens D, XXX, $6, a, b, k$, polished, $d, e$, rough, related to "Westerly granite" of Rice and Gregory), "Millstone granite," is a quartz monzonite between medium and dark gray, smoke colored, and of even-grained granitic, fine texture, with feldspars to $0.2 \mathrm{inch}$, but mostly under $0.1 \mathrm{inch}$, and mica to $0.1 \mathrm{inch}$. Its constituents, named in descending order of abundance, are: Whitish to buff striated soda-lime feldspar (oligoclase-albite), much of it kaolinized and micasized and intergrown with quartz circular in cross section; translucent gray. potash feldspar (microcline and a little orthoclase), little altered; medium șmoky quartz, with some cavities in sheets; biotite (black mica), some of it chloritized, and very little muscovite or bleached biotite. Accessory minerals: Magnetite (fifth in abundance), allanite (sixth in abundance), pyrite, apatite, zircon. Secondary minerals: Kaolin, a white mica, limonite from allanite, calcite, chlorite.

An estimate of the mineral percentages by the Rosiwal method, applied to a camera-lucida enlargement (25 diameters) of a thin section, yields these results with a mesh of 1.7 inches and total linear length of 40.8 inches:

Bstimated mineral content of Millstone quartz monzonite.

Soda-lime feldspar (oligoclase-albite)

Potash feldspar (miçrocline and orthoclase) 
The average diameter of the particles calculated from the same measurements is 0.0354 inch.

This granite effervesces somewhat freely with cold dilute muriatic acid. R. C. Wells, a chemist of the United States Geological Survey, finds that it contains 0.31 per cent. of $\mathrm{CaO}$ (lime), soluble in warm dilute (10 per cent) acetic acid, which indicates a content of 0.55 per cent of $\mathrm{CaCO}_{3}$ (lime carbonate, calcite), the presence of which mineral is also shown by the microscope.

A transverse test (No. 9764) made at the United States arsenal at Watertown, Mass., in 1896, on a piece of this granite 18 inches long by 1.02 by 1.02 inches and with 15 inches between end supports, gave a modulus of rupture of 2,029 pounds, the piece breaking under 138 pounds.

This is a brilliant, somewhat fine-grained, smoke-colored monumental and inscriptional granite without mineral contrasts excepting on close inspection. Its texture is about one-third as fine as that of the coarser "Blue Westerly" granite (New England Granite Works quarry, 0.0112 inch).

It takes a high polish, but the polished face shows magnetite and some pyrite. It hammers and cuts medium gray, thus affording a marked contrast of shade to the polished face, which is dark gray. ${ }^{1}$

A pinkish variety (specimen D, XXX, 6,i), "Millstone Pink," no longer quarried, is a quartz monzonite of medium inclining to dark slightly pinkish gray, with unevenly distributed cherry-red stains. Its texture is a trifle coarser, the feldspars and mica mostly under 0.15 inch. Its composition is identical with that of the other but includes secondary hematite, which causes the cherry-red spots.

The quarry, opened in 1830, measures about 800 feet in a $\mathrm{N}$. $40^{\circ} \mathrm{W}$. direction, with a width varying from about 150 to 300 feet owing to two embayments on the northeast wall, and has a depth of 50 to 150 feet. $^{2}$

Rock structure: The granite is capped on the northeast wall by several masses of gneiss up to 25 feet thick with a foliation striking N. $70^{\circ} \mathrm{W}$, and dipping $25^{\circ} \mathrm{N}$. $20^{\circ}$ E. At the shore south the same gneiss strikes N. $85^{\circ}$ E. and dips steep north with pegmatite dikes 2 to 3 feet thick. The plane of contact between the granite and the gneiss remnants is in places vertical, in others horizontal or gently inclined, the original complete outline of that plane having evidently been very irregular. In the central embayment 15 to 20 feet of granite overlie a sagging strip of the gneiss 5 to 10

${ }^{1} \mathrm{~J}$. S. Newberry in 1884 described it as "a dark-gray granite of fine, homogeneous texture, showing strong contrast of color between polished and dressed surfaces." Teath .Census U. S., vol. 10, 1884, p. 321.

a See Kemp, op. cit., XXXVI, fig. 2 , for a view of the quarry as it appeared between 1888 and 1898. 
feet thick. Large dikes of pegmatite, starting at the contact, penetrate the gneiss and in places the gneiss is cut up by an intricate network of pegmatite and aplite dikes. The gneiss (specimen D, XXX, $6, f$, "Mamacoke gneiss," No. 36, of the State preliminary gẹologic map) appears to be a black and white banded biotite granite gneiss of fine to medium texture. The granite sheets, lenticular, normal, and mostly 2 to 8 feet thick, but 6 to 12 inches in the upper 20 feet of the southeast end and 6 inches to 2 feet in the upper 15 feet; of central northeast side, dip $20^{\circ} \mathrm{N}$. $65^{\circ} \mathrm{E}$. There are two sets of joints: Set A, striking N. $40^{\circ}$ W., vertical, forming parts of the northeast and southwest walls and a 30 -foot heading at the north-northwest corner is spaced 6 inches to 33 feet but mostly 3 to 10 feet; set $\mathrm{B}$, striking north to N. $10^{\circ}$ E., vertical to steep west, occurs at greater and irregular intervals. A little sea water enters the quarry at the bottom through some of these joints. Flow structure, indicated by biotitic bands, strikes $\mathrm{N}$. $45^{\circ}-60^{\circ} \mathrm{W}$. and $\operatorname{dips} 30^{\circ} \mathrm{SW}$, but near the northwest end of quarry the bands are tortuous, doubling over on themselves, as shown in figure $8, a$. A block in the storage yard with a concentric structure of this kind probably formed part of a turn in one of these granite currents. The rift is reported as dipping $5^{\circ}-10^{\circ} \mathrm{N} .80^{\circ} \mathrm{E}$., and the grain as vertical, with N. $65^{\circ}$ E. course. Pegmatite and aplite dikes dip $30^{\circ}$ both northwest and southeast at intervals of 3 to 10 feet. . One with large biotite crystals strikes N. $55^{\circ} \mathrm{E}$. There are many inclusions. One of

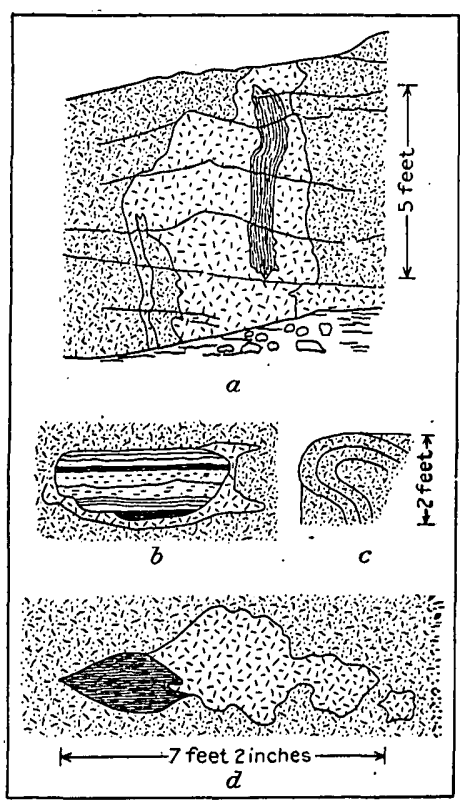

Fuciure 8.-Details at Millstone quarry. (a) Vertical section of pegmatite dike in quart\% monzonite, with inclusions of biotite gneiss (after a photograph by E. F. Burchard, U. S. Geol. Survey); (b), horizontal section of inclusion of biotite gneiss, 20 by 8.5 inches, partly surrounded with pegmatite, in quartz monzonite; (c), vertical section of tortuous flow structure, consisting of blotite sheets; $(d)$, horizontal section of inclusion of gneiss associated with very coarse pegmatite in quartz monzonite.

banded biotite gneiss, 20 by $8 \frac{1}{2}$ inches (fig. $8, b$ ). Another of the same gneiss, 20 by 20 feet, has a very irregular outline, with small outlying fragments, and adjoins a 6 by 3 foot mass of pegmatite with particles to 5 inches across. This mass and a smaller inclusion are shown in figure $8, d$. The granite is somewhat banded about the large inclusion. Another, near the northwest end and bottom of quarry, measures 35 by 25 feet. It is a black diorite gneiss, 
(specimen $\mathrm{D} ; \mathrm{XXX}, 6, h$ ) consisting of oligoclase-andesine, hornblende, quartz, and biotite, with accessory titanite. It is crossed by quartz veins, some of which start at the granite, others within the granite. A vertical pegmatite dike, 3 to 5 feet wide, in the upper granite mass referred to, contains an inclusion of biotite gneiss about 5 feet by 6 inches, with its long axis in vertical position. (See fig. $8, a$.) Rusty stain is about 2 inches thick on sheet surfaces. Niles in 1.876 mentioned the crushing of channel cores and cramping of drills at this quarry by northeast-south west compression. ${ }^{1}$

The plant comprises two derricks, one of them with a 110 -foot mast and capacity of 50 tons, two hoisting engines, two Blondin carriers and engines, a locomotive crane, a locomotive, an air compressor (capacity under 500 cubic feet of air per minute) four large rock drills, twelve air hand tools, a surfacer, lathe for stones 30 by 2 feet, a polishing lathe, four vertical polishers, two steam pumps, a stone crusher (capacity 50 cubic yards a day), and a 75-horsepower steam engine.

Transportation is by a mile siding from New York, New Haven \& Hartford Railroad at Millstone station, and also by short siding to dock, which admits vessels of 12 -foot draft at low tide.

The product is used for monuments and buildings and the waste for breakwater riprap, road, and concrete material. Specimens: Saratoga Monument, interior, entrance, and all but upper 10 feet of exterior; also a polished inscribed tablet of the Millstone Pink; base, pedestal, and cap of P. T. Barnum monument, Bridgeport; and George W. Childs mausoleum, Philadelphia.

SOMERS QUARRY.

The Somers quarry is in Waterford Township, $2 \frac{1}{2}$ miles west-southwest of New London, on the east side of Durfy Hill near Graniteville. (See fig. 7.) -Operator, Patrick Somers, R. F. D., Waterford, Conn.

The granite (specimen D, XXX, 14, $b$, related to "Westerly Granite " of Rice and Gregory) is a quartz monzonite of medium inclining to dark buff gray color and of even-grained granitic fine texture, with feldspar mostly under 0.1.inch but up to 0.2 inch and mica mostly under 0.05 inch but up to 0.1 inch. This rock is overlain by a few feet of similar but pinkish granite (specimen D, XXX, 14, $a$ ). Both effervesce slightly with muriatic-acid test.

This granite is finer textured than that of the Millstone quarry, and specimen $14, b$ is a little lighter in shade. As the quarry deepens the stone will probably be found to be suitable for monuments.

1 Niles, W. H., The geological agency of lateral pressure exhibited by certain movements of rocks: Froc. Boston Scc. Nat. Hist., vol. 18, 1875-1876, p. 279. 
The quarry, opened in 1902, is 70 feet square and averages 5 feet in depth.

Rock structure: The sheets are irregular, 1 to 8 feet thick, dipping $30^{\circ}$ E. Joints: Set A, striking nearly east to west, vertical, are spaced 9 to 20 feet. Set B, striking north to south, dip west, discontinuous; one only. There is some pegmatite.

The plant consists of a hand derrick.

Transportation is by cart $3 \frac{1}{2}$ miles to New London.

The product has thus far been used for building and trimmings.

WATERFOWD QUARRY.

The Waterford quarry is in Waterford Township, $3 \frac{1}{2}$ miles southsouthwest of New London, $2 \frac{3}{4}$ miles south of Waterford station, and a mile east of Pleasure Beach. (See Pl. I and fig. 7.) Operator, Booth Bros. \& Hurricane Isle Granite Co., 207 Broadway, New York.

The granite (specimens $\mathrm{D}, \mathrm{XXX}, .5 a, b$, rough, $d$, polished and hammered, related to "Westerly granite" of Rice and Gregory), "Connecticut white," is a quartz monzonite of medium buff gray shade and of even-grained granitic fine texture, with feldspars to 0.2 inch, rarely 0.3 inch but mostly under 0.1 inch, and slender micas to 0.15 inch, rarely 0.2 inch but mostly not over 0.1 inch. The long axes of the micas are parallel to the rift. Its constituents, in descending order of abundance, are milk-white soda-lime feldspar (oligoclase-andesine) kaolinized and micasized; cream-colored potash feldspar (microcline and a little orthoclase) slightly kaolinized and intergrown with quartz more or less circular in cross section; light smoky quartz with hairlike crystals of rutile, rare cavities in sheets and some rift cracks parallel thereto; biotite (black mica), some of it chloritized and very little muscovite or bleached biotite. Accessory minerals: Magnetite (fifth in order of abundance), apatite, zircon, allanite; no pyrite detected. Secondary minerals: A white mica, kaolin, calcite, chlorite, limonite.

An estimate of the mineral percentages by the Rosiwal method applied to a camera-lucida enlargement (25 diameters) of a thin section yields these results with a mesh of 1 inch and a total linear: length of 27 inches:

Estimated mineral percentages in quartz monzonite of Waterford quarry.

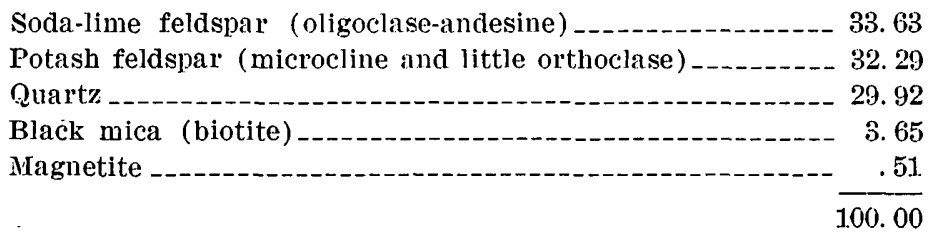

The average diameter of the particles, calculated from the sime. measurements, is 0.0206 inch. 
The stone effervesces with cold dilute muriatic acid. R. C. Wells, a chemist of the United States Geological Survey, finds that it contains 0.29 per cent of $\mathrm{CaO}$ (lime), soluble in warm dilute (10 per cent) acetic acid, which indicates a content of 0.51 per cent of $\mathrm{CaCO}_{3}$ (lime carbonate, calcite), the presence of which mineral is also shown by the microscope.

The following analysis (No. 12757) of this granite, made for the company by Ricketts \& Banks, of New York, is given here for reference:

Analysis of quartz monzonite from Watcrford quarry.

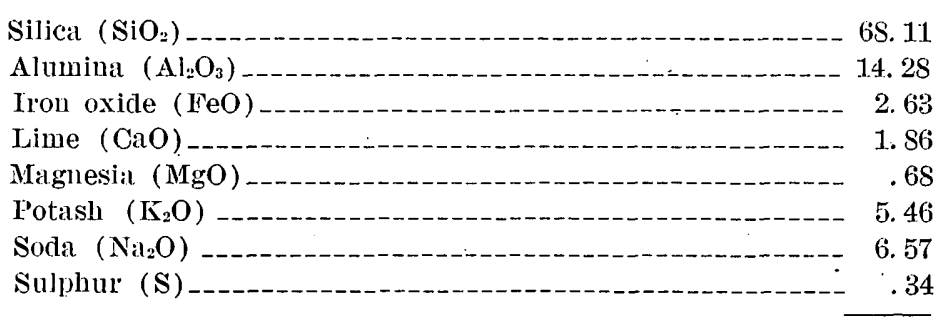

99.93

Ira H. Woolson, E. M., of Columbia University, made two compression tests on cubes of 2-inch edges in 1896, with these results (rift and grain directions not noted) :

\begin{tabular}{|c|c|c|c|}
\hline Test No. & $\begin{array}{c}\text { First } \\
\text { crack. }\end{array}$ & $\begin{array}{c}\text { Maximum } \\
\text { stress. }\end{array}$ & $\begin{array}{c}\text { Ultimate } \\
\text { strength. }\end{array}$ \\
\hline & & & $\begin{array}{c}\text { Poundls jer } \\
\text { sq. in. }\end{array}$ \\
$1575 \ldots .$. & $\begin{array}{r}\text { Pounds. } \\
65,000\end{array}$ & $\begin{array}{r}\text { Pounds. } \\
93,100\end{array}$ \\
32,000 & 97,600 & 22,921 \\
\hline
\end{tabular}

This is a very fine-grained monumental and inscriptional granite. of buff medium gray tint without mineral contrasts. It is finer than the Millstone granite and of lighter shade, and about half as fine as "Blue Westerly," which averages 0.0099 inch per particle. ${ }^{1}$

It takes a high polish. The polished face shows a little magnetite and is of medium inclining to dark gray shade, while the hammered face is light gray, to which lightness the stone owes its trade name. This property of hammering and cutting light it possesses in common with Westerly, Groton, Millstone, and other quartz monzonites. Its adaptation to fine architectural and sculptural work is shown in Plates VI, and VII, $A$, and its lightness when hammered in Plate VI.

The quarry, opened about 1878, measures about 600 feet from east to west by 150 feet across at east end and 250 at west end, and from 75 feet to 125 feet in depth. The stripping of sand and bowlders averages 10 feet in thickness. 


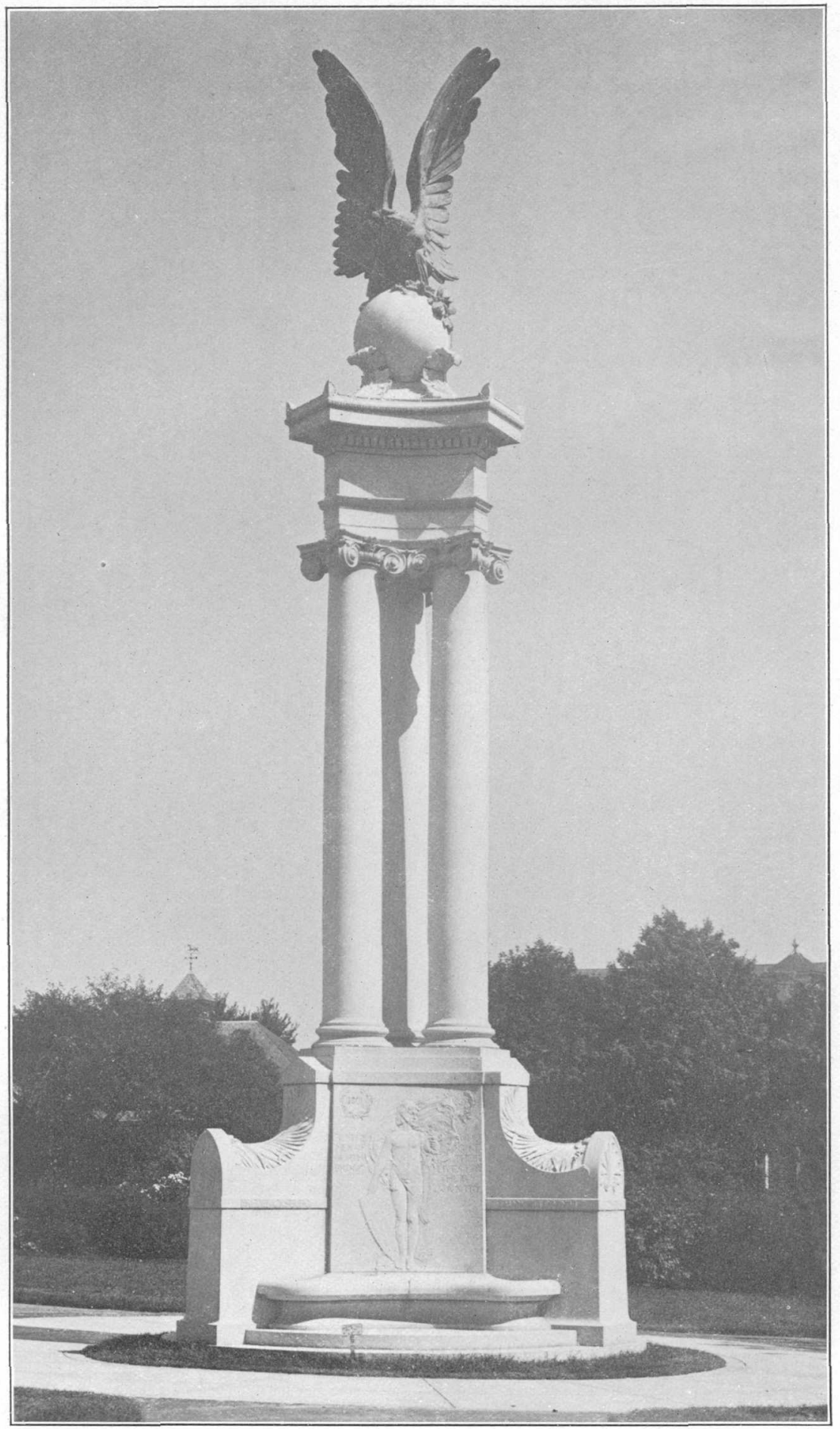

SOLDIERS' AND SAILORS' MONUMENT AT WHITINSVILLE, MASS., SURMOUNTED BY BRONZE EAGLE.

The monument is of hammered buff-gray fine-grained quartz morzonite ("Connecticut white granite") from the Booth quarry at Waterford. A. D. F. Hamlin, architect; H. A. MacNeil, sculptor. Height to tof of ball, 30 feet. See page 114. 


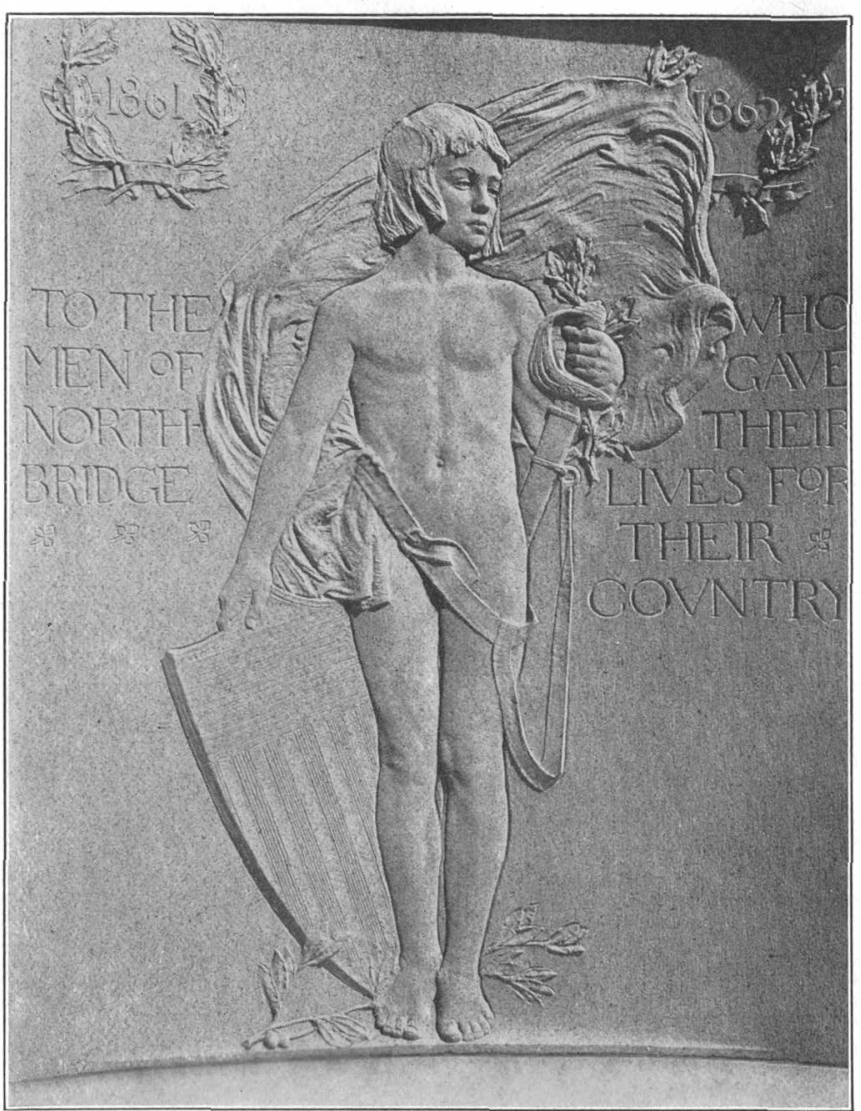

A. PANEL With BAS-RELIEF at BASE Of MONUMENT SHOWN IN PLATE VI. This is of fine-grained quartz monzonite from Waterford, and shows its adaptation to lettering and carving. Height of relief, half an inch. See page 114.

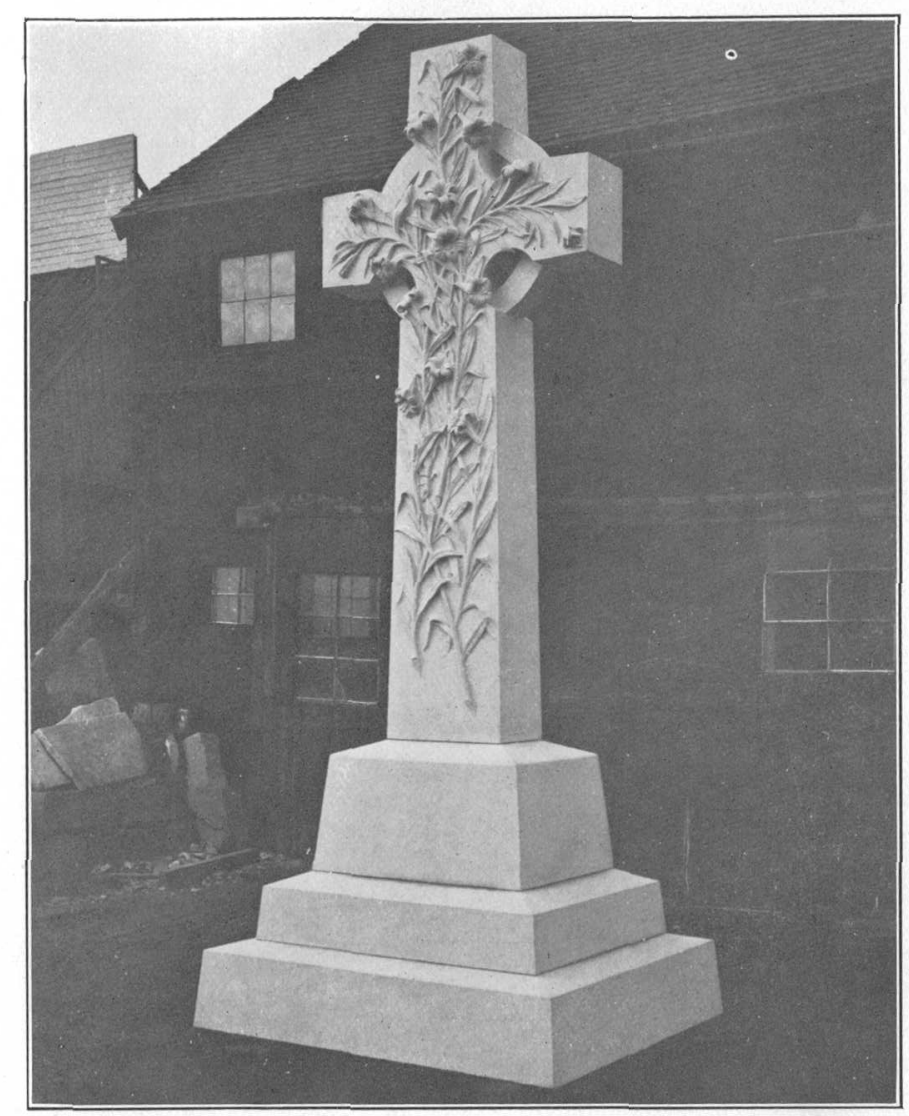

B. CARVED MONUMENT OF GREENISH-GRAY FINE-GRAINED QUARTZ MONZONITE FROM THE SALTER QUARRY AT GROTON.

Maximum relief of carving, $2 \frac{3}{4}$ inches; height of cross, 12 feet. See page 92. 
Rock structure: The granite occurs in two dike-like masses, 30 and 40 feet thick, alternating with three masses of gneiss, the central one of which is 20 to 30 feet thick, all striking N. $80^{\circ} \mathrm{E}$. and dipping $30^{\circ}-$ $45^{\circ}$ S. $10^{\circ}$ E. The relations are shown in figure 9. The $\mathrm{g} n \mathrm{n}$ iss foliation strikes N. $45^{\circ}-60^{\circ}$ W. and dips about

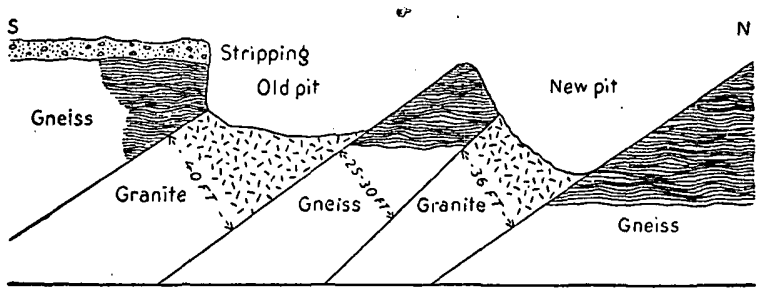
$400^{\circ} \mathrm{NE}$, but in places is nearly horizontal. The two granite masses are apparently connected in the center of the quarry by a small dike of the granite crossing

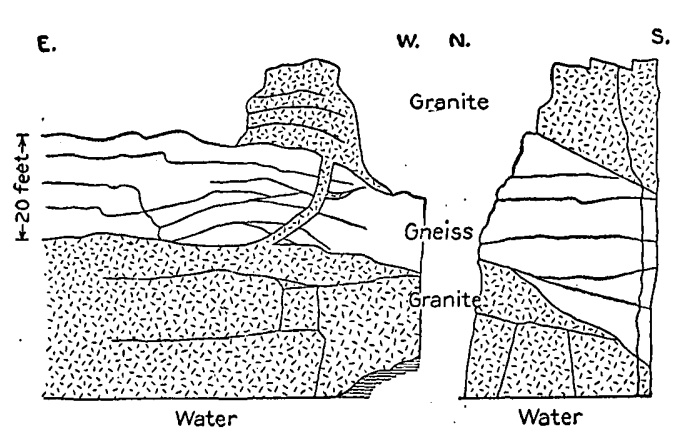

Figure 10.--Relatious of granite and gneiss in center of Waterford quarry. At left section looking south; at right looking east. s. the gneiss mass, as shown in figure 10. This gneiss (specimen D, XXX, 5, c; "Mamacoke gneiss," No. 36, of the State preliminary geologic map) is a black and white banded finegrained quartz - monzonite gneiss, consisting, in descending order: of abundance, of light smoky quartz, milk-

white oligoclase, very little microcline, and biotite. The granite sheets, 1 to 9 feet thick, are lenticular, irregular, dipping south and southeast at $15^{\circ}-22^{\circ}$. The sheet structure of the gneiss is not continuous with that of the granite, as shown in figures 10 and 11. Joint, rift, and grain courses are shown in figure 12 . Joints: Set A is vertical, spaced 3 to 20 feet; set B, vertical or steep

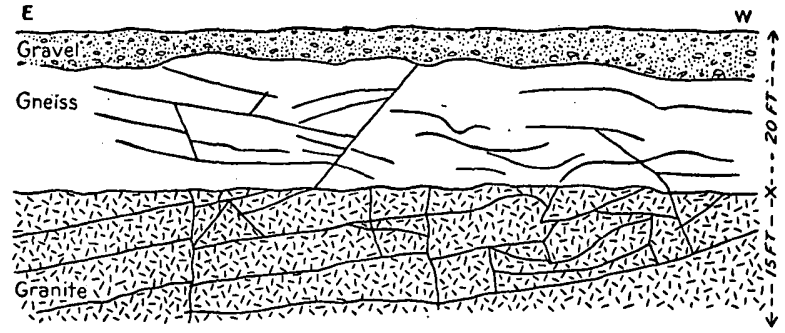

Figure 11.-Discordant sheet structure in granlte and gneiss on south wall of Waterford quarry.

west, spaced 3 to 50 feet; set $\mathrm{C}$ dips $50^{\circ}-75^{\circ} \mathrm{NW}$. and is spaced 2 to 75 feet. The rift dips $10^{\circ} \mathrm{S} .15^{\circ} \mathrm{E}$., with the long axes of the biotite scales, and the grain $75^{\circ} \mathrm{N} .15^{\circ} \mathrm{W}$, and the hardway is vertical. 
In splitting along the rift the granite is reported as breaking more readily from the west side than from the north. Biotitic knots to 6 inches in diameter are rare. Inclusions of the gneiss, 3 inches across and 2 by 3 feet, occur $2 \frac{1}{2}$ and 6 feet above the contact of upper granite dike, with underlying gneiss. The granite surface tends to weather spheroidally. ${ }^{1}$ Rusty stain is 2 to 6 inches thick on sheet surfaces.

The plant comprises a 25 -ton and 20-ton derrick, two hoisting engines, a Blondin carrier and engine, a locomotive crane, a locomotive, an air compressor (capacity 380 cubic feet of air per minute), two large rock drills, a number of air.plug drills, forty-five air hand tools,

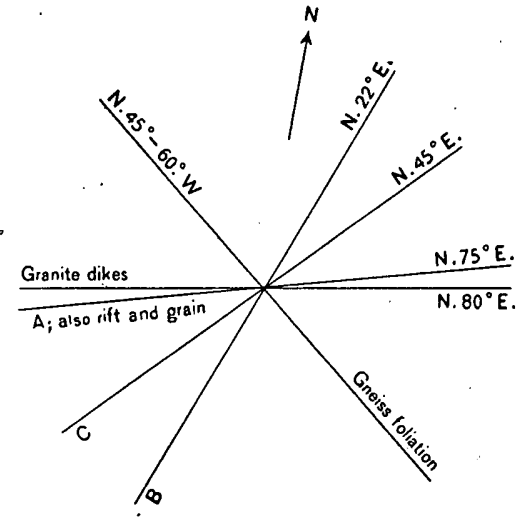

Finve 12.- Structure at Waterforidouarry three surfacers, two horizontal polishers, and two steam pumps.

Transportation is by cart a mile to the dock at Pleasure Beach, which admits vessels of 9 feet draft at low tide, or 2 miles to the New York, New Haven \& Hartford Railroad at Waterford station.

The product is used mostly for monuments and finds a market mostly in the Eastern States. Specimens: Soldiers Monument, Whitinsville, Mass., shown in Plates VI and VII, $A$; Dudley Celtic cross, Woodlawn Cemetery, New York; Littlefield shaft, Swan Point Cemetery, Providence; Hoy mausoleum, Mount Moriah Cemetery, Philadelphia; City Deposit Bank,.Pittsburg; basement of Clark residence, Riverside Drive, New York; addition to Williamsburg Savings Bank, New York.

\section{TOLLAND COUNTY.}

BOLTON.

PETERSON QUARRY.

The Peterson quarry is in Bolton Township, in the northeastern part of Minnehausch or Birch Mountain, about 2 miles southwest of Bolton village and $1 \frac{3}{4}$ miles southeast of Highland Park post office, in Manchester. (See Pl. I, p. 8.) Operator: Lawrence E. Peterson, South Manchester, Conn.

The granite (specimens D, XXX, 31, $a, b$, "Glastonbury granite gneiss," No. 15, of the State preliminary geologic map) is a biotite

1 See Bull. U. S. Geol. Survey No. 354, p. 58 and Pl. VIII, $A$, for an example of ovoidal weathering in Westerly quartz monzonite. 
granite gneiss of medium, slightly bluish gray shade, with conspicuous broad black streaks on the foliation face and of medium-grained unplicated very gneissose texture with porphyritic lenticular feldspars to 0.2 and 0.4 inch long. The quartz is in lamellaæ to 0.1 inch thick and the mica to 0.04 inch. The stone looks very different on its rift, grain, and hardway sides. Its constituents, in descending order of abundance, are bluish translucent potash feldspar (microcline and orthoclase) somewhat kaolinized; light smoky quartz strained and with cavities in parallel sheets and cracks parallel to or coinciding therewith; milk-white soda-lime feldspar (oligoclase to oligoclaseandesine); and biotite (black mica). Accessory minerals: Garnet, pyrite. Secondary minerals: A white mica, kaolin. Both feldspars are intergrown with quartz more or less circular in cross section. The stone does not effervesce with cold dilute muriatic acid.

The quarry is a small opening, made in 1908.

Rock structure: The sheets, 3 feet thick, dip gently east. The gneiss foliation strikes N. $10^{\circ}$ E. and is vertical. The rift is parallel to it and the grain horizontal and the hardway vertical, east-west. An 18-inch aplite dike runs parallel to the foliation. This (specimen D. XXX, 31, c) is of a medium bluish gray shade and of fine slightly gneissose texture. Its constituents, in descending order of abundance, are smoky quartz; bluish microcline, with orthoclase; milk-white soda-lime feldspar; and a little sparse biotite and pyrite. Its quartz and feldspar particles are mostly from 0.11 to 0.33 millimeter, with some porphyritic ones 0.54 to 0.84 . No effervescence with muriatic-acid test.

The contrasts in this stone are more marked than in any of the gneisses of Glastonbury described on pages $62-66$.

The stone is used for underpinning, cellar storie, etc.

WINDHAIM COUNTY.

STIERIING.

ONECO QUARRY.

The Oneco quarry is in Sterling Township, a mile southwest of Oneco village, near the Rhode Island line. (See Pl. I, p. 8.) Operator : Oneco Granite Co., Industrial Trust Co. Building, Providence, R. I.

The granite (specimen D, XXX, 22, a, "Sterling granite gneiss," No. 24, of the State preliminary geologic map) is a biotite granite gneiss of medium, inclining to dark, slightly bluish gray color and of fine-grained unplicated gneissose texture, with porphyritic feldspars to 0.2 and 0.4 inch and mica in fine parallel streaks 0.1 to 0.2 inch apart. Its constituents, named in descending order of abindance, are bluish potash feldspar (microcline intergrown with quartz 
more or less circular in cross section, also orthoclase) somewhat kaolinized; light smoky quartz, with cavities in parallel sheets and cracks parallel thereto; a little milk-white soda-lime feldspar (oligoclase), some of it kaolinized and micasized; biotite (black mica). Accessory minerals: Titanite (fifth in order of abundance), magnetite (or ilmenite), garnet, apatite, allanite, zircon. Secondary minerals : Kaolin, white mica. No effervescence with muriatic-acid test.

The quarry, opened about 1868, measures about 500 feet from northwest to southeast by 400 feet across, and is 5 to 35 feet deep. The stripping consists of 3 to 6 feet of sand.

Rock structure: The gneiss foliation strikes $\mathrm{N} .10^{\circ}-25^{\circ} \mathrm{W}$. and is vertical. The sheets, inches to 5 feet thick, dip $5^{\circ}-10^{\circ} \mathrm{SW}$. and $\mathrm{NW}$. Joints: Set A strikes N. $80^{\circ}-85^{\circ}$ E., vertical, forms the south wall, is spaced 10 feet and much more; set B ("blind seams" with quartz and pegmatite dikelets) strikes $\mathrm{N} .30^{\circ} \mathrm{W}$., dips $50^{\circ} \mathrm{E}$., and is spaced 3 to 10 feet. Biotitic surfaces (flow structure?), strike N. $30^{\circ} \mathrm{W}$. and $\operatorname{dip} 50^{\circ} \mathrm{N} .60^{\circ} \mathrm{E}$. The rift is reported as parallel to the gneiss folliation and the grain as vertical east to west, but not marked. There are pegmatite lenses of smoky quartz and pink feldspar, with purple fluorite and epidote crystals. Dikes of -whitish aplite to 4 inches thick strike N. $50^{\circ}$ W. and $\operatorname{dip} 30^{\circ}$ N. $40^{\circ}$ E. on the southwest wall. (See microscopic description under Marriott quarry.)

The plant "comprises three derricks, a hoisting engine, an air compressor, three surfacers, four air plug drills, and a stone crusher.

Transportation is by a siding three-fourths mile long to New York \& New England Railroad.

The product is used for building, curbing, paving, and the waste for crushed stone. The quarry became idle in the spring of 1908 .

\section{MARRIOTT QUARRY.}

The Marriott quarry is in Sterling Township, a mile southwest of Oneco station and one-fourth mile east of the Oneco quarry. (See Pl. I.) Operator: R. B. Marriott \& Sons, Oneco, Conn.

The granite (specimens D, XXX, $23 a, b$, "Sterling granite gneiss," No. 24, of the State preliminary geologic map) is a biotite granite gneiss of medium inclining to dark bluish gray color and of fine-grained unplicated gneissose texture, with porphyritic feldspars to 0.2 inch and 0.4 inch and mica in fine parallel streaks 0.1 to 0.2 inch apart. Its constituents are identical with those of the Oneco quarry stone, but the section shows secondary calcite and the stone effervesces slightly with cold dilute muriatic acid.

This granite gneiss is well adapted by its foliation for curbing and trimmings. It has a marked bluish tint and looks well hammered on the grain and hardway sides. 
The quarry, first opened in 1881, then idle till reopened in 1903, measures about 200 by 150 feet and 5 to 15 feet in depth. It has but just reached the bluer stone free from discoloration.

Rock structure: The gneiss foliation strikes north to N. $15^{\circ}$ $\mathrm{W}$. and is vertical. The sheets, 1 to 7 feet thick, with a few 6 -inch ones near the top, dip $5^{\circ} \mathrm{E}$. There are two sets of joints: Set A, striking N. $65^{\circ}$ E., vertical, forms the south wall and is spaced 3 to 30 feet; set B, striking north, vertical, forms east and west walls, and one on either side. The rift coincides with the foliation; the grain is horizontal and hardway vertical east to west. The stone breaks somewhat readily along the hardway. There are dikes of aplite to a foot thick, striking northwest and dipping steep southwest. A small one of these has a central band of ilmenite 0.3 inch thick. The aplite (specimen D, XXX, 23, c), like that of the Oneco quarry, is of light-cream color and very fine texture, with particles under $0.1 \mathrm{inch}$. In a thin section they range from 0.05 to 1.12 millimeters. Its constituents, in descending order of abundance, are: Clear, colorless quartz with cavities, microcline with orthoclase, oligoclase, minute and sparse biotite with accessory ilmenite, garnet, apatite. There is a 6-inch dike of smoky quartz with feldspathic border on the west side; also lenses of pegmatite with smoky quartz.

The plant comprises two hand and one steam derrick and a hoisting engine.

Transportation is by cart $1 \frac{1}{4}$ miles to Oneco station.

The product is used for curbing, building, trimmings, chimney caps, and paving, which is sent to Providence. Specimens: Cranske Mill addition at Moosup, Conn.

BENNET' BOWLDER QUARRY.

The Bennett Bowlder quarry is in Sterling Township, threefourths mile east of Sterling station and about $1 \frac{1}{4}$ miles west of the Rhode Island line. (See Pl. I.) Operator: Nelson A. Bennett, Sterling, Conn.

The granite (specimens $\mathrm{D}, \mathrm{XXX}, 24, a, d, e$, "Sterling granite gneiss," No. 24, of the State preliminary geologic map) is a biotite granite gneiss of general light pinkish gray color with conspicuous black streaks on the foliation face and of fine-grained, obscurely plicated gneissose much elongated porphyritic texture. It is marked by long tapering parallel lenses from 0.1 to 0.3 inch wide consisting of quartz or feldspar or mica. The rock has very different aspects on its rift, grain, and hardway faces. The rift or foliation face (specimen a) shows the lenses of black mica, pink feldspar, and smoky quartz. Along the grain (specimen $a$, smallest side) which is vertical to the foliation but parallel to the lenses, the mica is in 
very thin streaks, while along the hardway (specimen $e$ ), which is at right angles to the lenses, the rock is mottled with pink, gray, and black. The feldspar particles are to 0.2 inch. The constituents, in descending order of abundance, are light-pinkish potash feldspar (microcline and orthoclase), slightly kaolinized; light smoky quartz, with cavities in irregular sheets; cream-colored soda-lime feldspar (oligoclase-albite), somewhat kaolinized; biotite (black mica); and very little hornblende. Accessory minerals: Allanite, apatite, zircon. Secondary minerals: Calcite, kaolin. Slight effervescence with cold dilute muriatic acid.

A more pinkish granite (specimen $25, a$ ), from a point about $1 \frac{1}{2}$ miles north-northeast of Sterling station, a little north of Quaduck Brook, is of identical texture and composition, but the feldspars are more pinkish and more altered, the oligoclase-albite being much kaolinized and carrying calcite.

These stones are well adapted for the manufacture of paving blocks on account of their marked rift and grain and their smooth fracture along the hardway. The contrasts of shade and color in the fresh rock and its foliation make it suitable and attractive for other uses.

The quarry, if such it can be called, is part of a bowlder train about $1 \frac{1}{2}$ miles north to south by one-half mile in width, consisting of bowlders of one gneiss, which range from 5 to 30 feet in diameter and correspond to the underlying gneiss of the region. Indeed, some of the quarried "bowlders" are the weathered tops of ledges.

Rock structure: A 30-foot high ledge of the gneiss shows the gneiss foliation striking north and dipping $55^{\circ}$ to $70^{\circ} \mathrm{W}$. Sheets 2 to 5 feet thick dip $25^{\circ} \mathrm{N}$. $70^{\circ} \mathrm{W}$., and vertical joints striking east to west are spaced 1 to 10 feet. The rift coincides with the foliation, and the grain is at right angles to it but parallel to the lenses. Slight discoloration extends 10 inches from the surface.

The plant consists of five hand derricks and a forge, which are moved around to the bowlders.

Transportation is by cart to a 200 -foot siding one-quarter mile east of Sterling station.

The product is used for curbing, sills, caps, steps, buttresses, underpinning, and paving. The paving, which is the chief product, finds a market in Providence. The operator pays a royalty to the landowners on the bowlders he splits up.

STERLING QUARRY.

The Sterling quarry, an abandoned quarry three-fifths mile eastsoutheast of Sterling station, in the same township, is of interest because of the texture of its stone. 
The granite (specimen $\mathrm{D}, \mathrm{XXX}, 26, a$ ) is a biotite granite gneiss of medium inclining to dark bluish gray color and of fine gneissose texture, with fine matrix (particles under 0.2 inch) and porphyritic feldspars to 0.5 inch. Its constituents are the same as those of the Bennett bowlders, but the potash feldspar is bluish, the quartz clear and colorless, and the oligoclase milk-white to buff or faintly pinkish. The porphyritic texture is less obscured by elongation, and the biotite, while in parallel arrangement, is evenly distributed, as is also the quartz. Titanite is among the accessory minerals. This gneiss evidently originated in the same granite as that of the Bennett bowlders, but is less metamorphic; that is, its minerals have not been redistributed to the same extent, nor have its feldspars been subsequently as greatly altered.

Rock structure: The gneiss foliation strikes north and dips $70^{\circ}$ W. to $90^{\circ}$, and the sheets are from 6 inches to 3 feet thick.

\section{WINDHAM.}

\section{IJARRABEE QUARRY.}

The Larrabee quarry is in Windham Township, three-fourths mile northwest of the Willimantic railroad station. (See Pl: I.) Operator, Charles Larrabee, jr., Willimantic, Conn.

The granite (specimens D, XXX, 27, $a, b, d$, "Willimantic gneiss," No. 25, of the State preliminary geologic map) is a biotite granite gneiss of interbanded medium and very dark gray shades, with a few pinkish bands of muscovite gneiss, and some of pinkish pegmatite. Its texture is fine-grained gneissose with an unplicated lamination and particles under 0.1 inch, the feldspars in the pegmatite bands to 0.3 inch. The constituents of the medium gray bands, in descending order of abundance, are translucent potash feldspar (microcline partly kaolinized and orthoclase); light smoky quartz with some cavities; whitish soda-lime feldspar (oligoclase or oligoclase-andesine), some of it kaolinized and micasized and with calcite, also intergrown with quartz more or less circular in cross section; biotite (black mica), some of it chloritized, and a little muscovite or bleached biotite. Accessory minerals: Garnet (fifth in order of abundance), magnetite, pyrite, apatite, zircon, titanite. Secondary minerals: Kaolin, a white mica, calcite, chlorite. Much quartz is in lenses 0.28 by 2.24 millimeters. There are many fine particles of quartz and feldspar between the larger ones. In some specimens garnets are so abundant as to make minute pinkish bands. No effervescence with muriatic-acid test.

A thin section of a pinlish (not pegmatitic or garnetiferous) band shows the same potash feldspar pinkish and much kaolinized, light smoky quartz, oligoclase-andesine much altered, and muscovite 
instead of biotite, with allanite among the accessories. This is a muscovite gneiss.

The very dark bands are evidently due to more abundant biotite.

The quarry, opened about 1878, measures about 300 feet from east to west by 150 feet across and 40 feet in depth. The stripping consists of 5 to 10 feet of clay and sand.

Rock structure: The gneiss foliation strikes east to west and dips $10^{\circ} \mathrm{S}$. The sheets, 6 to 12 inches thick, coincide with the foliation.

There are three sets of joints. Set A, striking N. $40^{\circ}$ E., vertical,

$\cdots$ spaced 2 to. 8 feet, coated with quartz; set B, striking N. $5^{\circ}$.E., vertical; set C, striking $\mathrm{N}$. $80^{\circ} \mathrm{W}$., vertical, spaced 20 feet. The rift coincides with the foliation, but the grain is vertical, north to south, and difficult, and the hardway more so. Pegmatite and smoky quartz veins up to 2 feet thick coincide with the foliation and some with joints B and C. Some small pegmatite dikes carry a little apatite.

The plant comprises two steam derricks and one hand derrick. a hoisting engine, large rock drill, and a steam pump.

Transportation is by cart three-fourths mile to Willimantc.

The product is used for curbing, crosswalks, steps, and flagging; for which its uniformly straight foliation and its great toughness in transverse directions well adapt it.

\section{CLASSIFICATION OF THE GRANITES.}

The granites described in the foregoing pages may be divided scientifically into 10 groups, namely:

1. Biotite granite and granite gneiss.

2. Pegmatite biotite granite.

3. Biotite-muscovite granite gneiss.

4. Muscovite-biotite granite gneiss.

5. Biotite-liornblende granite gneiss.

6. Hornblende-biotite granite gneiss.

7. Egirite granite gneiss.

8. Quartz monzonite.

9. Quartz monzonite gneiss.

10. Mica diorite gneiss.

Some of these groups, however, need subdivision. The biotite granite may have white or pinkish feldspars. The biotite granite gneiss may be finely banded with white or pinkish feldspars, or may be injected with pegmatite, or plicated or porphyritic, etc. There are also differences in the lamination of some, and the quartz monzonite may have one or two micas. Including the division into granite and gneiss and other subdivisions, the quarried granites of the State fall into 20 well-defined varieties.

In the following list these varieties are systematically arranged and referred to some quarry or quarries where they are well exposed. 
Varieties of granite and gneiss quarried in Connecticut.

Biotite granite (a pink feldspar), Murray quarry, Stonington.

Biotite granite (white feldspars), Comstock quarry, Warren.

Riotite granite gneiss, finely banded (a pink feldspar), McIntosh quarry, Groton.

Biotite granite gneiss, finely banded (white feldspars), Collins quarry, Danbury; Borough quarry, Torrington.

Biotite granite gneiss, finely laminated, banded (white feldspars), Larrabee quarry, Windham.

Biotite granite gneiss, pegmatitic, Norcross quarry, Branford.

Biotite granite gneiss, porphyritic in places, Sachem Head quarry, Guilford.

Biotite granite gneiss, porphyritic and plicated, Hoadly Point, West quarry, Branford.

Biotite granite gneiss, porphyritic, much elongated, Glastonbury quarries and Webster quarry, Sterling.

Pegmatite biotite granite, Maccurdy quarry, Old Lyme.

Biotite-muscovite granite gneiss, Crissey quirry, Norfolk Benedict, Cornwall.

Muscovite-biotite granite gneiss, Rockside quarry, Roxbury; Mascetti quarry, Litchfield.

Muscovite-biotite granite gneiss, finely laminated, Burlison quarry, Bridgeport; Holbrook quarry, Ansonia.

Biotite-hornblende granite gneiss, Benvenue quarry, Middletown.

Hornblende-biotite granite gneiss, Selden Neck quarries, Lyme.

Tigirite granite gneiss, Joshua Rock quarry, Lyme; Flat Rock, Waterford.

Quart\% monzonite (biotite), Millstone and Waterford quarries, Waterford;

Salter quarry, Groton.

Quartz monzonite (biotite-muscovite), Plymouth quarry, Thomaston.

Quartz monzonite gneiss (biotite), Dunn quarry, Bristol.

Quartz monzonite flow gneiss (biotite), Masons Island quarry, Groton.

Mica diorite gneiss, Voorhis, Christiano, and Ritch quarries, Greenwich.

Economically considered these granites may be classified according to their uses as constructional, monumental, inscriptional (that is, giving by the contrast between their polished and hammered faces legibility to inscriptions), curbing and trimming (that is, adapted by their foliation for supplying long and thin pieces), and paving (that is, adapted by their marked rift and grain and smooth hardway fracture for the manufacture of paving blocks). Some granites are quarried alone for breakwater material (riprap) and others for road and concrete uses, not so much because of their peculiar fitness for these purposes as because of their unfitness for others and the location of the quarry with reference to transportation. These constitute a sixth or miscellaneous class.

In the following table all the granites described are grouped in these six economic classes. The trade name, scientific name, real general color and shade, and the texture of the stone are added in separate columns, and page references to the detailed descriptions of the granites and quarries are given. In defining their general color references to the black spots.or spangles are only given where they are very characteristic. 


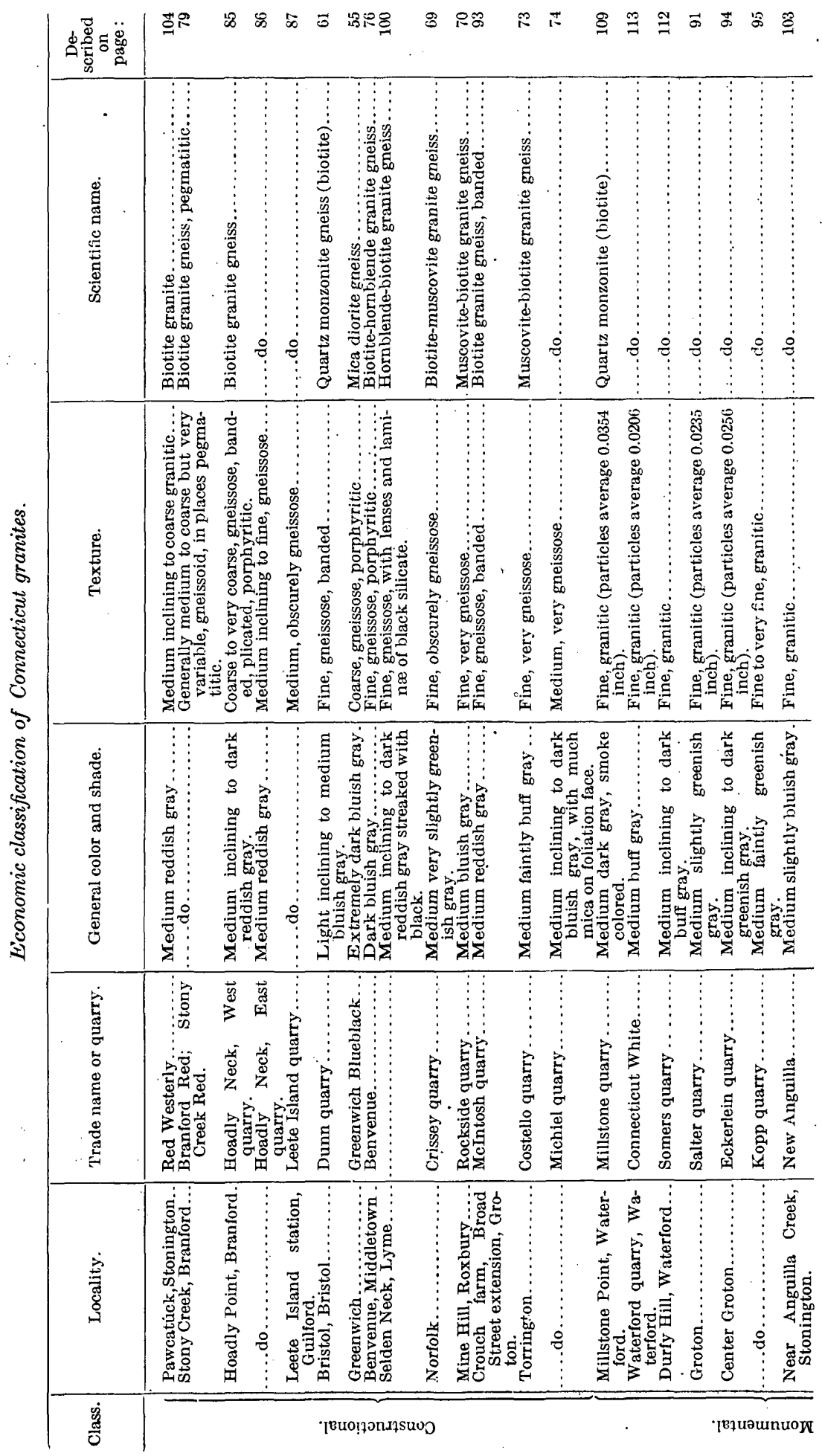




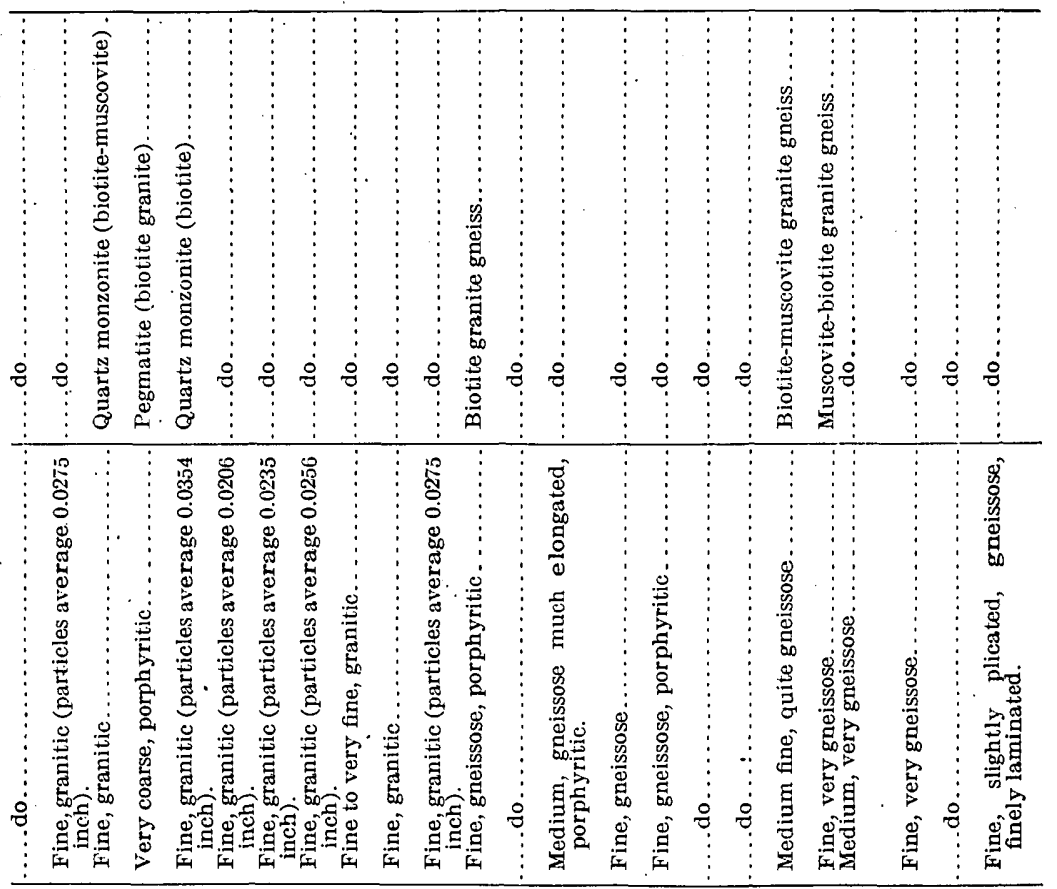

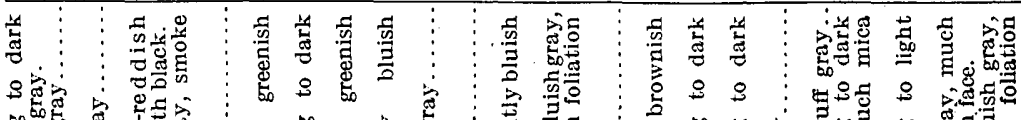

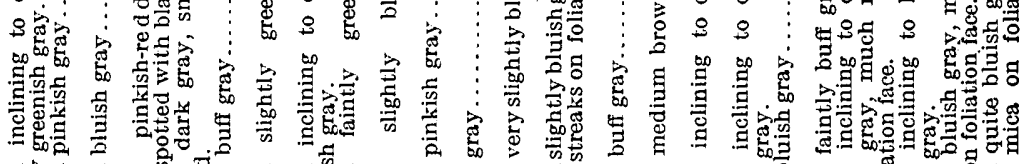

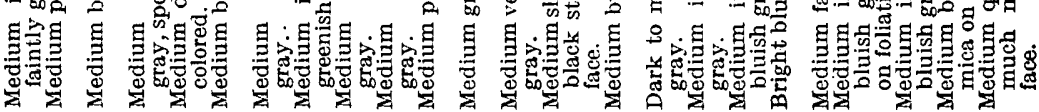

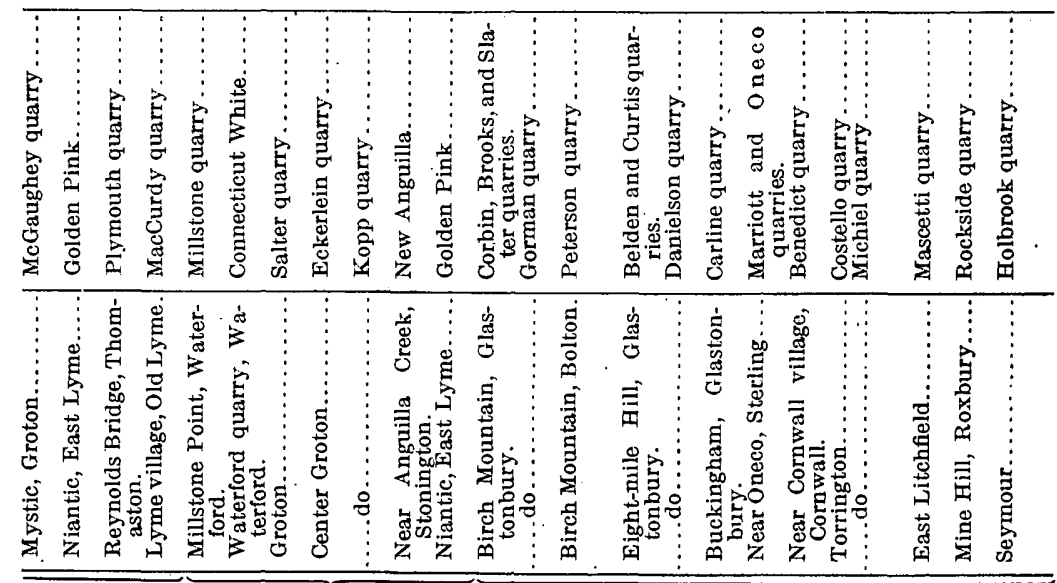




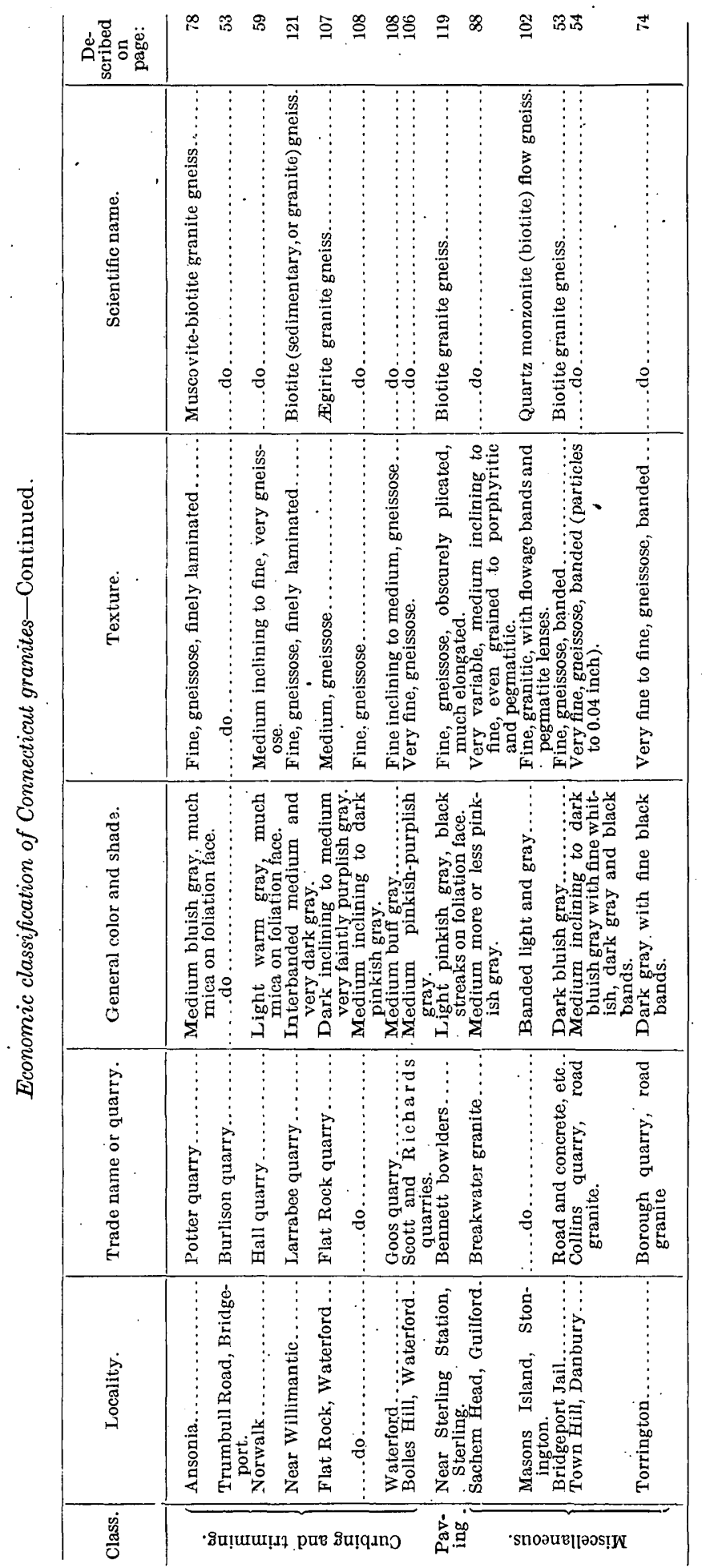




\section{COMMERCIAL VALUE OF THE GRANITES.}

As the price of a granite is usually an index of its quality the current prices. (1907-9) of a few granites of each class are here given. All, unless otherwise specified, are f. o. b. cars, per cubic foot, ordinary sizes, in the rough.

Constructional granites.-Stony Creek, "Branford Red," \$0.75 for dimension stock, $\$ 0.53$ for random. Hoadly Neck, $\$ 0.70$. Greenwich (Blue-black), $\$ 0.45$, boat, for dimension stock; $\$ 2.75$, boat, per long ton, for large random ashlar; $\$ 3.75$, boat, per long ton, for small random ashlar; $\$ 1.75$, boat, per long ton, for rubble, "Millstone Granite," for building, in pieces up to 30 cubic feet, a verage about $\$ 0.40, f$. o. b. quarries.

Monumental granites.-Waterford, "Connecticut White," $\$ 1.20$ to $\$ 1.80$, and "Millstone Granite," $\$ 1.25$, cars or boat, from 1 to 30 cubic feet. Niantic, "Golden Pink," $\$ 1.25$ to $\$ 2.25$, from 5 to 30 cubic feet.

Curbing and trimming granites.-Oneco (Marriott), $\$ 0.50$; Sterling (Bennett), \$0.35. Glastonbury (Belden) curbing, \$0.45 per running foot at quarry, with cartage of 10 miles to rail. Seymour (Holbrook), $\$ 0.40$ per running foot, 18 inches deep and 4 inches wide. Roxbury (Mine Hill), $\$ 0.30$ to $\$ 0.40$. Waterford (Flat Rock), $\$ 0.45$, delivered in New London.

Miscellaneous.-Guilford (Sachem Head) breakwater granite, $\$ 0.999$ per long ton dumped at breakwater, 12 miles from quarry, minimum weight of blocks 500 pounds. Greenwich riprap, per long ton, boat, $\$ 1.25$.

\section{STATISTICS OF GRANITE PRODUCTION.}

By Altha T. Coons.

The figures presented in the following table show the value of the granite quarried in Connecticut during the last 10 years, according to the reports by the quarrymen to the United States Geological Survey. The values given represent the selling value to the quarryman free on board at point of shipment, but exclude all freight. rates. When the stone is cut or dressed at the quarry the value of the dressed stone is given. This applies especially to the stone quarried and sold for uses as building and as monumental stone. The greater part of the stone sold for riprap and rubble was used for jetty and breakwater work.

$97730^{\circ}-$ Bull. $484-11-9$ 
The following table shows the value of granite quarried in Connecticut from 1899 to 1908 , inclusive, by uses:

Production of granite in Connecticut from 1899 to 1908, inclusive, by uses.

\begin{tabular}{|c|c|c|c|c|c|c|}
\hline \multirow{2}{*}{ Year. } & \multicolumn{2}{|c|}{ Building. } & \multicolumn{2}{|c|}{ Monumental. } & \multicolumn{2}{|c|}{ Paving blocks. } \\
\hline & Rough. & Dressed. & Rough. & Dressed. & $\begin{array}{l}\text { Number of } \\
\text { blocks. }\end{array}$ & Value. \\
\hline 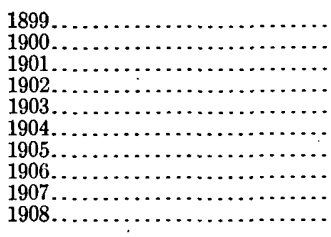 & $\begin{array}{r}a \$ 78,855 \\
a 90,379 \\
108,959 \\
116,745 \\
\therefore 59,421 \\
87,955 \\
158,126 \\
158,189 \\
31,928 \\
33,833\end{array}$ & $\begin{array}{r}\$ 167,889 \\
110,583 \\
94,611 \\
200,262 \\
408,875 \\
289,772 \\
230,736 \\
428,915 \\
110,600 \\
117,242\end{array}$ & $\begin{array}{l}(b) \\
(b) \\
\$ 26,267 \\
28,862 \\
26,164 \\
23,371 \\
28,238 \\
44,433 \\
26,302 \\
: 23,218\end{array}$ & $\begin{array}{r}\$ 82,766 \\
52,535 \\
70,894 \\
66,899 \\
58,811 \\
42,202 \\
52,125 \\
64,019 \\
112,393 \\
58,672\end{array}$ & \begin{tabular}{|r|}
$c 483,000$ \\
$c 372,600$ \\
$c 652,000$ \\
$c 817,000$ \\
$c 1,581,500$ \\
$1,422,656$ \\
999,215 \\
806,863 \\
854,136 \\
292,485
\end{tabular} & $\begin{array}{r}\$ 25,722 \\
14,903 \\
29,340 \\
34,305 \\
63,260 \\
47,898 \\
42,983 \\
62,305 \\
37,666 \\
14,951\end{array}$ \\
\hline Year. & Curbing. & Flagstone. & $\begin{array}{c}\text { Riprap } \\
\text { and rubble. }\end{array}$ & $\begin{array}{c}\text { Crushed } \\
\text { stone. }\end{array}$ & $\begin{array}{c}\text { Other } \\
\text { purposes. }\end{array}$ & Total value. \\
\hline 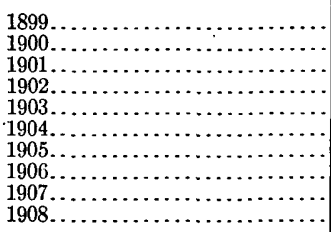 & $\begin{array}{r}\$ 12, \\
25, \\
14 \\
23,080 \\
24,398 \\
21,690 \\
22,091 \\
19,064 \\
24,551 \\
25,324\end{array}$ & $\begin{array}{r}371 \\
805 \\
386 \\
1,383 \\
2,235 \\
2,357 \\
999\end{array}$ & $\begin{array}{r}\$ 16,876 \\
31,492 \\
31,342 \\
40,894 \\
124,339 \\
32,698 \\
90,530 \\
174,287 \\
233,008 \\
303,101\end{array}$ & $\begin{array}{r}\$ 21,060 \\
32,450 \\
14,300 \\
8,882 \\
12,169 \\
8,364 \\
5,336 \\
6,657 \\
10,510 \\
5,890\end{array}$ & $\begin{array}{r}\$ 12,600 \\
4,329 \\
93,699 \\
3,998 \\
4,816 \\
13,920 \\
1,838 \\
9,674\end{array}$ & $\begin{array}{l}\$ 406,132 \\
357,566 \\
402,671 \\
524,629 \\
871,941 \\
558,334 \\
636,364 \\
974,024 \\
591,153 \\
592,904\end{array}$ \\
\hline
\end{tabular}

$a$ Includes rough monumental.

$b$ Included in rough building.

c Estimate.

\section{GENERAL ECONOMIC CONCLUSIONS.}

In reviewing the economic data brought together in this bulletin several general facts will impress themselves on the reader. One is notably the varied character of the granites of the State. They range in grade of texture from the coarse pegmatite of Lyme and the coarse granite gneiss of Branford and Guilford to the fine quartz monzonites of Waterford, Niantic, and Groton. They vary, too, in kind of texture from the coarsely porphyritic of Hoadly Point and Greenwich to the medium and finely porphyritic of Glastonbury and Sterling, the finely laminated of Ansonia and Willimantic to the finely granitic of the quartz monzonites. Some of the gneisses present a very different texture in three directions. In some of the granites the micas are aligned with the rift. There is also considerable variety of color, shade, and mineral contrast. The diorite gneiss of Greenwich is a blue-black, the quartz monzonites are smoke-colored or medium greenish, bluish, or pinkish gray, but cut in light grays of corresponding tints. The pegmatite of Lyme is pinkish-reddish, the granite gneiss of Stony Creek and the granite of Pawcatuck are reddish. The gneisses of Sterling, Bolton, and Selden Neck are streaked 
with black and many of the gneisses are gray of various tints brightly spangled with mica on their foliation face.

There is also a great variety in the use made of these "granites." They are employed for the construction of breakwaters, forts, retaining walls, bridges, churches, libraries, universities, railroad stations, banks, business blocks, residences; for street paving, flagging, curbing, circulars, crosswalks; posts, steps, underpinning, buttresses, trimming for brick buildings, coping, chimney caps, tube linings; crushed granite for roads, concrete, artificial stone and curbing; obelisks, columns, sarcophagi, crosses, and other monuments, some of them delicately carved, as shown in Plate VII, and also bases for bronze statues.

The location of the granites and gneisses has much to do with the success of the industry. The constructional granites of Greenwich, Hoadly Point, and Stony Creek, and the monumental granites of Waterford, Millstone, and Groton are all near both rail and tidewater. The breakwater quarries of Sachem Head and Masons Island are necessarily at tidewater. The Glastonbury gneisses have long supplied the city of Hartford with curbing by means of one cartage of 8 to 10 miles. The Sterling quarries have easy rail communication with Providence for their curbing, trimming, and paving. In the western part of the State the Roxbury, Norfolk, and Thomaston quarries are on rail lines connecting with lines to the cities and the Cornwall and Torrington quarries are not far from the same lines.

The most notable products of the Connecticut granite quarries are the recently completed Connecticut River bridge at Hartford, consisting of nine arches of cut granite with a total length of 1,192 feet and width of 82 feet; the pedestal to the statue of Liberty in New York Harbor; the Soldiers and Sailors Monument at Whitinsville, Mass. (shown in Pl. VI) ; the obelisk at Sault Ste. Marie (shown in Pl. III, $B$, p. 48) ; the Battle Monument at West Point; the Channing Memorial Church at Newport, R. I., and the Catholic Cathedral at Brooklyn.

An industry which at one extreme enables a man to support his family by splitting up glacial bowlders into paving blocks and besides to pay the farmer a royalty on his bowlders, and which at the other commands sufficient capital and skill to bridge the Connecticut with granite arches or to finish such a work of art as the Soldiers Monument at Whitinsville, certainly has a wide economic extent. 


\section{GLOSSARY OF SCIENTIFIC AND QUARRY TERMS.}

ACCESSORY Minerals in granite are original constituents of the rock, found only in small, often only in microscopic quantity.

AcIDIc.' A term applied to rocks in which silicic acid (silica) or quartz predominates.

Allanite. An opaque black mineral (silicate), brown in thin section, one of the primary less common accessory constituents of granite, which contains from 12 to 17 elements, including 6 of the rarer ones. For analyses see Dana, E. S., System of Mineralogy, 6th ed., 1892, pp. 522-526.

ANricline. A term applied to granite sheets or sedimentary beds that form an arch.

APLITE. Fine-grained granite, generally occurring in dikes and containing little mica and a high percentage of silica.

BASIC. A term applied to rocks in which the iron-magnesia minerals and feldspars with lime and soda predominate, such as diabase or basalts.

BLACK HORSE. Term used by quarrymen to denote a dark biotite gneiss in contact with the granite.

BLIND sEams. Quarrymen's term for incipient joints.

BowIDER QUARRY. One in which the joints are either so close or so irregular that no very large blocks of stone can be quarried.

Channel. A narrow artificial incision across a mass of rock, which, in the case of a granite sheet, is made either by a series of contiguous drill holes or by blasting a series of holes arranged in zigzag order.

Cleavage, when applied to a mineral, designates a structure consequent upon the geometrical arrangement of its molecules at the time of its crystallization.

Close-Jornted. A term applied to joints that are very near together.

Crocus. A term used in some quarries to denote gneiss or any other rock in contact with granite.

CRUSH BORDER. A microscopic granular structure sometimes characterizing adjacent feldspar particles in granite in consequence of their having been crushed together during or subsequent to their crystallization.

CuT-orf. Quarrymen's term for the direction along which the granite must be channeled, because it will not split. Same as "hardway."

DENDRITES. Plantlike crystallization of iron or manganese oxides on the surfaces of fissures in any rock or mineral. Frost crystals on window panes are of like character.

Dike. A mass of granite, diabase, basalt, or other rock which has been erupted through a narrow fissure.

Dimension stone. A term applied to stones that are quarried of required dimensions.

Drp. The inclination from the horizon, given in terms of degrees, of a sheet, joint, heading, dike, or other structural plane in a rock.

DrIFT. Sand and bowlders deposited by the continental glacier.

Drumlin. Oval hillock of clay and bowlders formed beneath the ice sheet of the glacial epoch.

Erosion. The wearing away of portions of a rock by such natural agencies as stream or ice action. 
Exfoliation. The peeling of a rock surface in sheets owing to changes of temperature or other causes.

Faulting. The slippage of a rock mass or masses along a natural fracture.

l'Low structure. The parallel arrangement of the minerals in granite or other igneous rock in the direction of its flowage during its intrusion.

Grope. A rock cavity lined with crystals. Geodes in granite are attributed to steam or gas bubbles.

GraIn in granite is practically the direction in which the stone splits "next easiest," the "rift" being that in which it splits most readily.

Grout. A term applied to the wast'e material of all sizes obtained in quarrying stone.

Grow-on. Quarrymen's term to designate the place where the sheet structure dies out, or the place where two sheets appear to grow onto one another.

HARDway. The direction at right angles to both rift and grain in which granite does not split readily. (See Cut-off.)

HEADING. A collection of close joints.

Heading-seam. See Joint.

Hematrte. An oxide of iron $\left(\mathrm{Fe}_{2} \mathrm{O}_{3}\right)$, which, when scratched or powdered, gives a cherry-red color.

Igneous. A term applied to rocks that have originated in a molten condition.

Jornrs. More or less steeply inclined fractures which cross the granite sheets and which are attributed to various stresses.

Kinolin. A hydrous silicate of alumina derived from the alteration of feldspar.

Kaolinization. The process by which a feldspar passes into kaolin.

KNots. A term applied by quarrymen to dark gray or black objects, more or less oval or circular in cross section, which are segregations of black mica or hornblende formed in the granite while in a molten state. English quarrymen call them "heathen."

KNox Hole. A circular drill hole with two opposite vertical grooves which direct the explosive power of the blast.

LEwrs Hors. An opening made by drilling two or three holes near together and chiseling out the intervening rock.

Limonite. A hydrous oxide of iron $\left(2 \mathrm{Fe}_{2} \mathrm{O}_{3}, 3 \mathrm{H}_{2} \mathrm{O}\right)$; a hydrated hematite, which. when scratched or powdered, gives a brownish rust color.

Matrix. The general mass of a rock which has isolated crystals; sometimes called groundmass.

Mirlimeter. French decimal linear measure, the thousandth part of a meter or the tenth part of a centimeter. It is equivalent to nearly $0.04 \mathrm{inch}$, the meter being $39 \frac{10}{2}$ inches.

Monolith. A column or monument of one stone.

Motron. A term used in granite regions to designate small paving-block quarries.

Opfitic. A term applied to microscopic rock texture to designate a mass of longish interlacing crystals, the spaces between which have been filled with minerals of later crystallization.

OrEï. A term applied in the Quincy quarries to Quincy granite which has been rendered valueless by the alteration of its agirite particles.

Pegmatite. A rery coarse granite occurring in irregular dikes or lenses in granites and some other rocks. 
Phenocryst. A term applied to isolated crystals visible to the unaided eye and lying in the mass of a rock of igneous origin.

Plagioclase. A term applied to all those feldspars that are not potash feldspars.

Polarized light. Light whose vibrations, unlike those of ordinary light, which are in all directions, are in only one plane. Polarized light is used in the microscopic study of rocks.

Porphyritic. A term applied to rock texture to Gesignate the presence of isolated crystals in a general mass (matrix or groundmass) of finer material.

Pseudomorph. Signifies false form, and designates a crystal in which, owing to various chemical changes, the original mineral has been more or less replaced by others. The form of the crystal no longer corresponds to the mineral.

Quartz monzonite. Technical designation for a granite in which the percentages of soda-lime and of potash feldspar are nearly the same or in which the former exceeds the latter. In ordinary granites the amount of soda-lime feldspar is relatively small.

Random stone. A term applied by quarrymen to quarried blocks of any dimensions. (See definition of dimension stone.)

RIFT. A quarrymen's term to designate an obscure microscopic cleavalge in granite which greatly facilitates quarrying.

RuN. A term used by quarrymen in connection with "rift;" apparently to denote the course of the deflection of the rift due to gravity, strain, or other not yet understood cause.

SALT Horse. Quarrymen's term for aplite.

SAND sEams. Quarry term for more or less minute veins or dikes of. muscovite (white mica) with some quartz, in cases also with feldspar.

SAND streaks. Same as sand seams.

SAP. Quarrymen's term for ferruginous discoloration along sheet or joint surfaces.

Schist. A rock made up of flattish particles arranged in rough parallelism, some or all of which have crystallized under pressure.

Schistosity. The quality॰ of being like a schist.

SEAM. Quarrymen's term for joint.

Secondary minerais. Minerals whose presence is due to the alteration of the original minerals.

Sepdmentary. A term designating those rocks that consist of particles deposited under water.

Segregation. The scientific term for "knot," a collection of material separated from other material. A vEIN of segregation is one formed by the filling of a fissure with mineral matter originating in the surrounding rock.

SERICITE. A more or less fibrous form of muscovite (potash mica), often resulting from the alteration of feldspar.

Shakes. Quarrymen's term to designate a somewhat minute close-joint structure; which forms along the sheet surface as a result of weathering.

SheET QUARRY. A quarry in which the granite lies in sheets, crossed by widespaced steep joints. 
SLICKEnsides. The polished and grooved faces of a joint or bed caused by motion and friction.

STRATN-SheET. Quarrymen's term for granite sheets produced by present compressive strain.

Stratified. A term applied to rock consisting of originally horizontal beds or strata.

Strike. The direction at right angles to the inclination of a plane of bedding, a sheet, or joint, etc.

Strippivg. The material (sand, clay, soil, etc.) overlying a rock of economic value, which must be removed before quarrying.

Spectfic gravity. The weight of a rock or mineral compared to that of a body of distilled water of the same bulk.

SubJoint. Minor joints diverging from or parallel to the regular joints.

Srncline. A geological term for the trough part of a wave-like sheet or bed of rock.

TruL. A mixture of clay and bowlders deposited by glaciers.

TonIng-In. Quarrymen's term for the wedging in of the end of a granite sheet under an overhanging joint, probably in consequence of the faulting of the sheets along the joint. It is also applied to the overlapping of lenticular sheets.

. "ToE NaILs." Curved joints intersecting the sheet structure, in most cases striking with the sheets, in some differing from them in strike $45^{\circ}$ or more.

Twin crystals. Two adjacent crystals which have formed with the poles of - their main axes in opposite or different directions.

Weathering. The decomposition of a rock owing to the action of the weather.

White HoRse. Term used by quarrymen to denote a light-colored gneiss, aplite, or pegmatite. 



\section{INDEX.}

A.

Page.

Age of Connecticut granites

Ansonia, quarries in.

Aplite, description of

78-79

$39-40$

B.

Becker, G. F., on sheet structure in granite..

Becket gneiss, description of................

Bedding of granite, description of ............. $29-30$

Belden quarry, description of............... $64-65$

Benedict quarry, description of........... 67-68

Bennett Bowlder quarry, description of... 119-120

Benvenue quarries, description of.......... 76-78

Biotite, occurrence of, in granite........... 15

Bolton, quarry in . . . . . . . . . . . . .

Branford, quarries in................... 79-87

Branford granite gneiss, description of...... 24

Branner, J. C., on sheet structure in granite.. 31

Bridgeport, quarries in ................. 52-54

Bristol, quarries in ..................... 61-62

Bristol granite gneiss, description of ......... . 22

Brookfield diorite, description of............ 23

Brooklyn quarry, description of . .......... 84-85

Brooks quarry, description of.............. 66

Brownstone, production of............... 13

Burlison quarry, description of ........... 52-53

C.

Calkins, F. C., acknowledgment to......... 7

Canterbury granite gneiss, description of..... 23-24

Carline quarry, description of.............. 62-63

Carlson quarry, description of ............ 98-99

Christiano Hamilton A venue quarry, description of

Christiano Oak Ridge quarry, description of.

Collins quarry, description of. ............ 54-55

Collinsville granite gneiss, description of.... 22

Comstock prospect, description of.......... $\quad 76$

Connecticut, geologic history of........... 11-13

Geological and Natural History Survey of, references to.................

Contacts of Connecticut granites, character of.

Coons, Altha T., statistics of granite production by ................... 127-128

Corbin quarry, description of.............. 62

Cornwall, quarries in................... 67-68

Costello quarry, description of.............. 73

Crissey quarry, description of.............. 69

Curtis quarry, description of............... $65-66$

$$
\text { D. } a
$$

Dale, T. Nelson, Economic discussion by ... 52-133 field.work by.................... 7 geologic observations at the quarries by .. 45-51 on structure, rock variations, weathering, and discoloration of granitic rocks ..................... $26-45$

Danbury, quarries in................... 54-55
Danbury granodiorite gneiss, description of.. $\quad 23$ Danielson quarry, description of............ 64

Davidson quarry, description of ........... 79

Decomposition of granite, description of..... 43-45

Dikes, aplite, occurrence of.............. 49-50

basic, description of .................. 41

granitic, description of................. $39-40$

occurrence of :.................... 48

pegmatite, occurrence of............... 48-49

Discoloration, occurrence of............... 42-43

Dunn quarry, description of................ 61-62

E.

East Lyme; quarries in.................. 97-99

Eastford granite gneiss, description of........ 23

Eckerlein quarry, description of............ 94-95

Economic conclusions................ 128-129

Emmons, S. F., on sheet structure in granite.. 32

Erosion by Mississippi River.............. 10

F.

Fairfield County, quarries of ............ $52-60$

Faults, description of..................... $38-39$

Feldspar, occurrence of, in granite......... 15

Finlay, G. I., on rift in granite.............. 27-28

Fissility, definition of................... 11

Flat Rock quarry, description of......... 107-108

Flow structure, description of............ $\quad 26$

in Connecticut granites............... 47

Fossils, absence of, from schists and gneisses. 12

\section{G.}

Geodes, description of .................. $\quad 42$

occurrence of......................... 51

Geologic history of Connecticut............ 11-13

Gilbert, G. K., on sheetstructure in granite.. 31

Glastonbury, quarries in................ $62-67$

Glastonbury granite gneiss, description of.... 23

Glossary of scien tific and quarry terms.... 130-133

Gneiss, comparison of, with granite......... 16-17 distribution of ..................... 22 porphyritic, composition and occurrence

of......................... 21-22

Goos quarry, description of............. 108-109

Gorman quarry, description of............ 63-64

Grain, description of.................... 26-29

Granite, Connecticut, age of............... 25

Connecticut, commercial value of....... $\quad 127$ comparison of, with gneiss........... 16-17 distribution of.................... 22 economic classification of............ 123-126 economic conclusions on........... 128-129 intrusions of, nature of............. 24-25 mineral content of................ 14-15 production of............... 14, 127-128 scientific classification of........... 122-123 specimens of...................... 8 use of the name................... $7-8,14$ 
Greenwich, quarries in................... $55-59$

Gregory, Herbert E., on granites and granite gneisses of Connecticut .......... 14-25

scientific discussion by ............... 9-14

Groton, quarries in .................... 91-97

Guilford, quarries in.................. 87-90

H.

Haddam granite gneiss, description of......

Hall quarry, description of ............... 59-60

Hard way, description of................. 20

Hartford county, quarries of.............. 60-67

Headings, description of................ 37-38

Hermann, O., on sheet structure in granite... 31

Hoadly Neck quarries, description of. ...... 85-87

Holbrook quarry, description of ........... 90-91

Hornblende, occurrence of, in granite....... 15

I.

Inclusions, description of . occurrence of.

India, quarrying granite in

Intrusions, granitic, nature of............. 24-25

J.

Jail quarry, description of ............... 53-54 Joint structure, description of........... 11,36-37 Joints, direction of...................... 51 Joshua Rock quarry, description of........ 99

\section{K.}

Kaolinization of granite, description of...... 44 Knots, description of .................. 41-42 Kopp quarry, description of ............... 95

I.

Larrabee quarry, description of........... 121-122

Leete Island quarry, description of . . ...... 87-88 Limestone, production of ................. 13 Litchfield, quarries in ..................... 68

Litchfield county, quarries of............. 67-76

Lyme granite gneiss, description of.

24

Lyme; quarries in. 99-100

\section{M.}

MacCurdy quarry, deseription of ......... 100-102 McGaughey quarry, description of.......... 96-97 McIntosh quarry, deseription of............ 93-94 Malnati Pink quarry, description of........ 97-98 Mamacoke gneiss, description of ............ 24 Maromas granite gneiss, description of...... 23 Marriott quarry, description of . ........... 118-119 Mascetti quarry, description of ............ 68 Masons Island quarry, description of ...... 102-103 Merrill, G. P., on sheet structure in granite.. 31 Michiel quarry, description of.............. 73-74 Middlesex county, quarries of.............. 76-78 Microstructure, character of............... 46-47 Middletown, quarries in.................. 76-78 Millstone quarry, description of........... 109-112 Mineral veins, occurrence of.............. 50 Monson granite gneiss, description of........ 23 Murray quarry, description of ........... 104-106
N.

Page.

New Anguilla quarry, description of...... 103-104

New Haven county, quarries of............ 78-91

New London granite gneiss, description of... 24

New London county, quarries of.......... 91-116 Norcross quarry, description of ............ 79-82

Norfolk, quarries in..................... 69

Norwalk, quarries in .................. 59-60

\section{O.}

Old Iyme, quarry in ................. 100-102 Oneco quarry, description of .............. 117-118

P.

Pegmatite, composition and occurrence of ... 18-20 description of ....................... 40 Peterson quarry, description of .......... 116-117 Plants, quarrying. See particular districts, places, etc.

Plymouth quarry, description of........... 72-73 Porphyry, composition and occurrence of.... 20-22 Potter quarry, description of............. 78-79 Prospect porphyritic gneiss, description of... 22 Pyrite, occurrence of, in granite........... 16 Pyroxene, occurrence of, in granite........ 15

\section{Q.}

Quarries, description of, method of . .......... Quarrying, methods of. Sec particular districts, places, etc.

Quartz, occurrence of, in granite.

R.

Richards quarry, description of......... 106-107

Rift, description of ................... 26-29 direction of, in Connecticut granites..... 46

Ritch quarry, description of.............. 57-58

Rocks, fissility and jointing of ........... 10-11 igneous, origin of .................. $\quad 3$ metamorphic, origin of ............... 9

of Connecticut, age of............... 11-12

sedimentary, origin of ................ 9

under pressure, behavior of............ 10

Rockside quarry, description of............ 70-71

Roxbury, quarries in................... $70-71$

$\mathrm{S}$.

Sachem Head quarry, description of....... 88-90 Salter quarry, description of.............. 91-93 Sap, occurrence of ..................... $42-43$ Scott quarry, description of.............. 106 Segregations, description of.............. 41-42 Selden Neck quarries, description of........ 99-100 Seymour, quarry in................... 90-91 Seymour Street quarry, description of...... 62 Shake structure, description of ........... 33,44 Sheet structure of granite, description of..... 29-36 Sheets, production of, in India............ 33 Slater quarry, description of..............66-67 Somers quarry, description of............ 112-113 Specimens of Connecticut granite. See particular districts, places, ctc.

Stering, quarries in ................. 117-121 Sterling granite gneiss, description of ...... 23 
Trap rock, production of .

Treadwell prospect, description of.......... 55

$\mathrm{V}$.

Veins, quartz, occurrence of.............. 40

zeolite in ......................... 51

Voorhis quarry, description of........... 55-57

Warren, quarry in .................... 76

Warth, H., on artificial production of sheets

in granite..................... 33

Waterford, quarries in............... 106-116

Waterford quarry, description of ........ 113-116

Weathering of granite, description of....... 44

Wells, R. C., chemical work by............ 7

Whittle, C. L., on rift in granite........... 27-28

Willimantic gneiss, description of........... 23

Windham, quarry in ................. 121-122

Windham county, quarries of............ 117-122

$\mathrm{Z}$.

Zeolite, occurrence of ................... 51 